\title{
Paraonidae (Polychaeta) from the Capbreton Canyon (Bay of Biscay, NE Atlantic) with the description of eight new species
}

\author{
FLORENCIO AGUIRREZABALAGA ${ }^{1,2}$ and JOÃO GIL ${ }^{3}$ \\ ${ }^{1}$ EHU/UPV Donostiako Irakasleen Unibertsitate Eskola, Oñati plaza 3, 20018 Donostia, Spain. \\ ${ }^{2}$ S.C. INSUB, Zemoria 12, Apdo 3223, 20013 Donostia. E-mail: p.agirrezabalaga@ehu.es \\ ${ }^{3}$ Centre d’Estudis Avançats de Blanes (CSIC), Carrer d'accés a la Cala Sant Francesc, 14, E-17300 Blanes, Girona, Spain. \\ E-mail: gil@ceab.csic.es
}

\begin{abstract}
SUMMARY: Nineteen species of paraonid polychaetes, belonging to five genera, were collected from bathyal depths at the Capbreton Canyon, Bay of Biscay, NE Atlantic. Levinsenia kantauriensis n. sp., Aricidea sardai n. sp., A. bifurcata n. sp., A. mirunekoa n. sp., A. maialenae n. sp., A. nekanae n. sp., Paradoneis bathyilvana n. sp. and P. mikeli n. sp., are new to science; Aricidea (Allia) antennata, Levinsenia flava, Paradoneis drachi and Paraonides myriamae are new records for the Atlantic, and Paradoneis eliasoni to the Iberian coasts.

Keywords: Polychaeta, Paraonidae, new species, Capbreton Canyon, Bay of Biscay.

Resumen: Paraonidae (Polychaeta) del Cañón de Capbretón (Golfo de Vizcaya, Atlántico ne) con la DESCRIPCIÓN DE OCHO NUEVAS ESPECIES. - Durante un estudio sobre las comunidades bentónicas de los fondos batiales del cañón de Capbretón, Golfo de Bizkaia, Atlántico NE, se recolectaron 19 especies de poliquetos paraónidos. Levinsenia kantauriensis n. sp., Aricidea sardai n. sp., A. bifurcata n. sp., A. mirunekoa n. sp., A. maialenae n. sp., A. nekanae n. sp., Paradoneis bathyilvana n. sp. y P. mikeli n. sp. son nuevas para la ciencia; Aricidea (Allia) antennata, Levinsenia flava, Paradoneis drachi y Paraonides myriamae son nuevas citas para el Atlántico; y Paradoneis eliasoni se cita por primera vez para las costas ibéricas.
\end{abstract}

Palabras clave: Polychaeta, Paraonidae, nueva especie, Cañón de Capbretón, Golfo de Bizkaia.

\section{INTRODUCTION}

Deep-sea polychaetes are still largely unknown. Some environments peculiar to the deep sea, such as hydrothermal vents, mud volcanoes, methane clathrate deposits, and whale bones, are receiving a great deal of scientific attention, which is revealing a richness of species sometimes beyond expectations (e.g.: Desbruyères and Toulmond, 1998; Dahlgren et al., 2004; Rouse et al., 2004; Glover et al., 2005; Desbruyères et al., 2006; Ravara et al., 2007; Hilário and Cunha, 2008; Pleijel et al., 2008; Rouse et al.,
2008). However, although polychaete fauna represent the largest part of the deep-sea floor community there is little information on them in other deep sea regions, such as abyssal plains, continental rises, and canyons. On many occasions, the material is obtained as a by-product of other studies, and is not treated for taxonomic work. This leads to the specimens being in poor condition or fragmentary, which is usually useful for general faunistic surveys, but not for fine taxonomic research.

From 1987 to 1990, four oceanographic cruises were conducted in the Capbreton submarine canyon 
onboard the RV-“Côte d'Aquitaine". In these cruises, the bathyal macrofauna was carefully sampled and sorted, which yielded a large amount of polychaete specimens in excellent condition for fine taxonomic studies, which is evidenced by the increasing number of published papers based on this material (San Martín et al., 1996; Aguirrezabalaga et al., 1999, 2001, 2002; Núñez, et al., 2000; Aguirrezabalaga and Ceberio, 2003, 2005a,b, 2006; Aguirrezabalaga and Carrera-Parra, 2006), and, in the present paper, by the good SEM pictures.

Among the Capbreton material, about 300 specimens of Paraonidae, a family well represented and highly diversified in deep-sea environments, were collected. Over the last years, the number of known species of this family has increased to about 100 , mainly due to the use of finer mesh screens and numerous research projects that focus on the benthic diversity of the continental slopes and other deep-sea habitats (Blake, 1996). At the generic level Strelzov (1973), in his worldwide monograph, distinguished 6 taxa: Aricidea (with 4 subgenera: Aricidea sensu stricto, Acesta, Allia and Aedicira), Cirrophorus (including Cirrophorus, Paradoneis and Paraonides), Paraonis, Paraonella, Sabidius and Tauberia. Later, Katzmann and Laubier (1975) considered Cirrophorus and Paradoneis as two different genera, according to the presence/absence of a prostomial median antenna, as did Campoy (1981), Hartley (1981), Mackie (1991) and Blake (1996), among others. In turn, McLelland and Gaston (1994) followed Strelzov (1973). The genus Tauberia was synonymized with Levinsenia (Melville, 1979) and the subgenus Acesta was renamed as Acmira, as the name Acesta was already in use for a genus of limilid molluscs (Hartley, 1981). Moreover, Paraonides was considered as a valid genus, with Paraonella as a junior synonym (Castelli, 1988). Thus, the family Paraonidae currently consists of 7 genera: Aricidea (with the subgenera: Aricidea sensu stricto, Acmira, Allia and Aedicira), Cirrophorus, Levinsenia, Paradoneis, Paraonis, Paraonides and Sabidius.

In this paper, we describe 19 paraonid species belonging to five genera found in Capbreton canyon: Aricidea (9 species), Cirrophorus (1 species), Levinsenia (3 species), Paradoneis (5 species) and Paraonides (1 species), with particular attention paid to Levinsenia kantauriensis n. sp., Aricidea sardai n. sp., A. bifurcata n. sp., A. mirunekoa n. sp., A. maialenae n. sp., A. nekanae n. sp., Paradoneis bathyilvana $\mathrm{n}$. sp. and P. mikeli n. sp., which are new to science; as well as to Aricidea antennata Annenkova, 1934, Levinsenia flava (Strelzov, 1973), Paradoneis drachi Laubier and Ramos, 1974 and Paraonides myriamae Katzmann and Laubier, 1975, which are new records for the Atlantic Ocean; and Paradoneis eliasoni Mackie, 1991 a new record for the Iberian coasts.

\section{MATERIALS AND METHODS}

The specimens were collected in the Capbreton Canyon, Bay of Biscay, NE Atlantic. Eighteen sta-
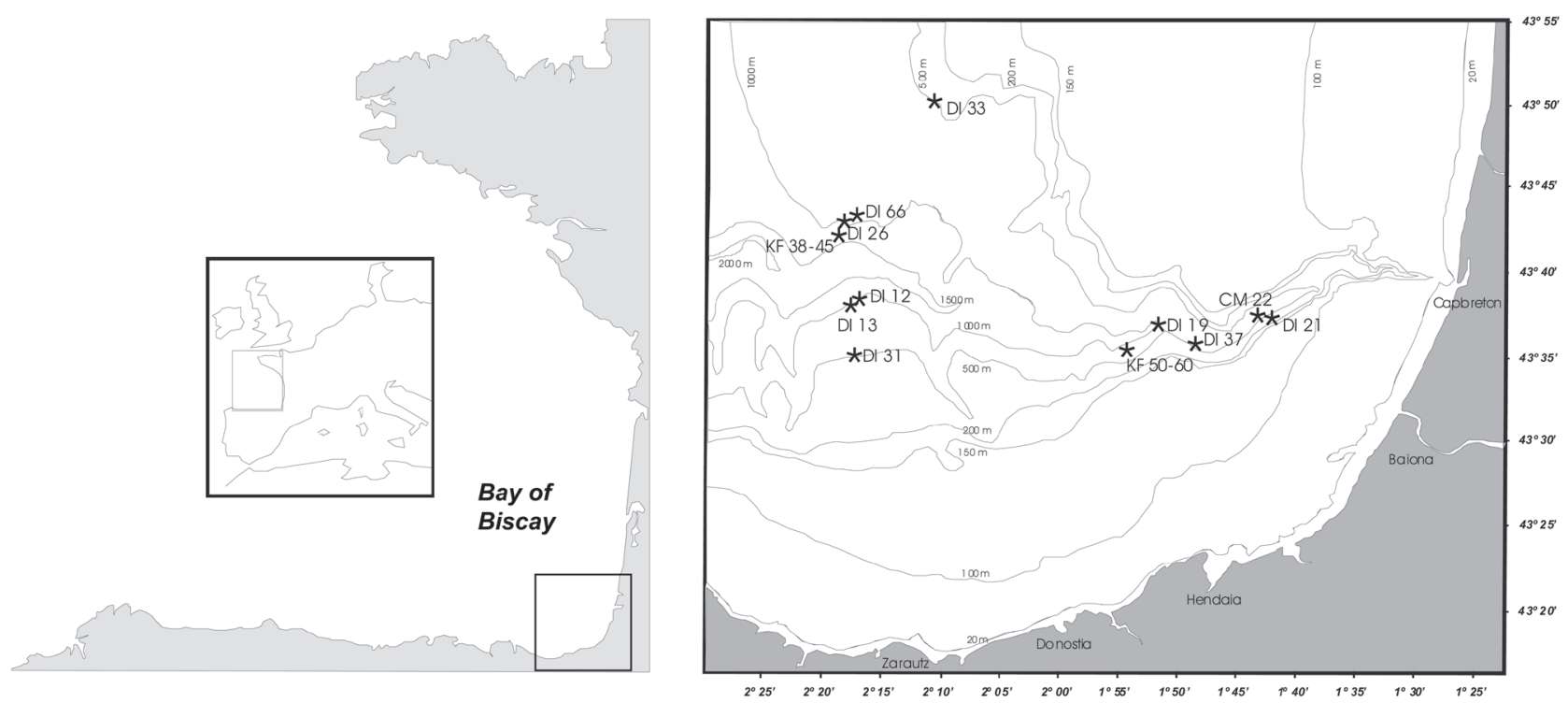

Fig. 1. - Map of Capbreton Canyon (Bay of Biscay) showing sampled stations with paraonid specimens. 
TABLE 1. - Main characteristics of the sampling stations. Date format is day, month, year. DI, Sanders-Hessler epibenthic dredge; KF, Flusha box-corer.

\begin{tabular}{|c|c|c|c|c|c|c|c|c|}
\hline Station & Date & $\begin{array}{l}\text { Position at the beginning } \\
\text { and the end of the tow } \\
\text { on the sea floor }\end{array}$ & Depth (m) & $\begin{array}{c}\text { Time of } \\
\underset{(\text { min })}{\text { dragging }}\end{array}$ & Station & Date & Position & Depth (m) \\
\hline \multirow[t]{2}{*}{ DI 12} & 06/07/1988 & $43^{\circ} 38.57^{\prime} \mathrm{N}-2^{\circ} 17.93^{\prime} \mathrm{W}$ & 1012 & 20 & KF 38 & $12 / 09 / 1989$ & $43^{\circ} 41.90^{\prime} \mathrm{N}-2^{\circ} 18.54^{\prime} \mathrm{W}$ & 1003 \\
\hline & & $43^{\circ} 38.33^{\prime} \mathrm{N}-2^{\circ} 18.11^{\prime} \mathrm{W}$ & 1113 & & $\mathrm{KF} 41$ & $12 / 09 / 1989$ & $43^{\circ} 42.02^{\prime} \mathrm{N}-2^{\circ} 18.30^{\prime} \mathrm{W}$ & 1004 \\
\hline \multirow[t]{2}{*}{ DI 13} & 06/07/1988 & $43^{\circ} 38.36^{\prime} \mathrm{N}-2^{\circ} 18.03^{\prime} \mathrm{W}$ & 1040 & 15 & KF 42 & $12 / 09 / 1989$ & $43^{\circ} 41.95^{\prime} \mathrm{N}-2^{\circ} 18.41^{\prime} \mathrm{W}$ & 1017 \\
\hline & & $43^{\circ} 38.08^{\prime} \mathrm{N}-2^{\circ} 18.14^{\prime} \mathrm{W}$ & 1007 & & KF 44 & $12 / 09 / 1989$ & $43^{\circ} 41.95^{\prime} \mathrm{N}-2^{\circ} 18.39^{\prime} \mathrm{W}$ & 1025 \\
\hline \multirow[t]{2}{*}{ DI 19} & 07/07/1988 & $43^{\circ} 37.48^{\prime} \mathrm{N}-1^{\circ} 52.52^{\prime} \mathrm{W}$ & 952 & 15 & KF 45 & $12 / 09 / 1989$ & $43^{\circ} 42.00^{\prime} \mathrm{N}-2^{\circ} 18.35^{\prime} \mathrm{W}$ & 1000 \\
\hline & & $43^{\circ} 37.46^{\prime} \mathrm{N}-1^{\circ} 52.66^{\prime} \mathrm{W}$ & 968 & & KF 50 & $14 / 09 / 1989$ & $43^{\circ} 35.35^{\prime} \mathrm{N}-1^{\circ} 55.15^{\prime} \mathrm{W}$ & 1000 \\
\hline \multirow[t]{2}{*}{ DI 21} & 07/07/1988 & $43^{\circ} 37.72^{\prime} \mathrm{N}-1^{\circ} 41.83^{\prime} \mathrm{W}$ & 580 & 15 & KF 52 & $14 / 09 / 1989$ & $43^{\circ} 35.27^{\prime} \mathrm{N}-1^{\circ} 55.04^{\prime} \mathrm{W}$ & 997 \\
\hline & & $43^{\circ} 37.43^{\prime} \mathrm{N}-1^{\circ} 41.99^{\prime} \mathrm{W}$ & 480 & & KF 57 & $14 / 09 / 1989$ & $43^{\circ} 35.37^{\prime} \mathrm{N}-1^{\circ} 54.90^{\prime} \mathrm{W}$ & 995 \\
\hline \multirow[t]{2}{*}{ DI 26} & 08/07/1988 & $43^{\circ} 42.89^{\prime} \mathrm{N}-2^{\circ} 18.71^{\prime} \mathrm{W}$ & 984 & 25 & & & & \\
\hline & & $43^{\circ} 43.25^{\prime} \mathrm{N}-2^{\circ} 18.80^{\prime} \mathrm{W}$ & 1029 & & & & & \\
\hline \multirow[t]{2}{*}{ DI 31} & $10 / 07 / 1988$ & $43^{\circ} 35.87^{\prime} \mathrm{N}-2^{\circ} 17.43^{\prime} \mathrm{W}$ & 505 & 15 & & & & \\
\hline & & $43^{\circ} 35.87^{\prime} \mathrm{N}-2^{\circ} 17.73^{\prime} \mathrm{W}$ & 512 & & & & & \\
\hline \multirow[t]{2}{*}{ DI 33} & $10 / 07 / 1988$ & $43^{\circ} 50.32^{\prime} \mathrm{N}-2^{\circ} 10.90^{\prime} \mathrm{W}$ & 495 & 15 & & & & \\
\hline & & $43^{\circ} 49.78^{\prime} \mathrm{N}-2^{\circ} 11.12^{\prime} \mathrm{W}$ & 492 & & & & & \\
\hline DI 37 & 08/07/1988 & $43^{\circ} 36.25^{\prime} \mathrm{N}-1^{\circ} 48.24^{\prime} \mathrm{W}$ & $\begin{array}{l}508 \\
576\end{array}$ & 15 & & & & \\
\hline \multirow[t]{2}{*}{ DI 66} & $16 / 09 / 1989$ & $\begin{array}{l}43^{\circ} 36.45^{\circ} \mathrm{N}-1^{\circ} 48.10 ' \mathrm{~W} \\
43^{\circ} 43.23^{\prime} \mathrm{N}-2^{\circ} 17.51 ' \mathrm{~W}\end{array}$ & $\begin{array}{c}576 \\
1026\end{array}$ & 5 & & & & \\
\hline & & $43^{\circ} 43.23^{\prime} \mathrm{N}-2^{\circ} 17.60^{\prime} \mathrm{W}$ & 1036 & & & & & \\
\hline
\end{tabular}

tions (Fig. 1, Table 1) were dredged either with a Sanders-Hessler epibenthic dredge (DI) or a Flusha box-corer (KF). Samples were sieved through a 0.5 $\mathrm{mm}$ mesh and the sorted specimens were preserved in a $10 \%$ formaldehyde-seawater solution.

Additional type specimens were also studied: the holotype of Aedicira mediterranea Laubier and Ramos, 1974 (A 843), loaned by the Muséum National d'Histoire Naturelle, Paris (MNHN); the holotype of Aricideabulbosa Hartley, 1984(ZB.1983, 1774), loaned by the British Museum of Natural History (BMNH); and the paratypes of Aricidea mariannae Katzmann and Laubier, 1975 (13079), and Aricidea pseudannae Katzmann and Laubier, 1975 (13080), loaned by the Naturhistorisches Museum Wien (NMW).

The types and representative specimens of the species described here are deposited in the Museo Nacional de Ciencias Naturales, Madrid (MNCN) and in the Sociedad Cultural de Investigación Submarina INSUB, Donostia (INSUB). In the examined material section, the number of specimens at each station is indicated between brackets. In the descriptions, " $1 / \mathrm{w}$ " means ratio length / maximum width at base of branchiae, and "l" and "max. l" refer to the length and the maximum length of branchiae respectively. The indicated coloration always refers to preserved specimens. Question marks (?) under the descriptions of Paradoneis mikeli n. sp. and Aricidea (Allia) sardai n. sp. indicate that part of the material identified respectively as Paradoneis lyra and Aricidea mediterranea, in the given references, probably belongs to the newly described species. However, this material was not revised in the present study, and is only presented as possibly belonging to the new species. Likewise, question marks in the species distribution designate the possible but unconfirmed presence of the new species in the indicated areas, based on the given references.

Terminology follows Strelzov (1973), Katzmann and Laubier (1975), Hartley (1981) and Blake (1996).

\section{SYSTEMATICS}

Family Paraonidae Cerruti, 1909

Genus Levinsenia Mesnil, 1897

Levinsenia flava (Strelzov, 1973)

(Figs. 2 and 3)

Tauberia flava, Strelzov, 1973: 144-145, Fig. 65 A-C.

Material examined. 56 specimens from Capbreton Canyon, Bay of Biscay, Atlantic Ocean (coordinates in Table 1): CB88/DI12 (2), CB88/DI13 (1), CB88/DI26 (4), CB88/DI31 (16), CB88/DI33 (32), CB89/KF38 (1).

Description. All specimens incomplete. Body long, slender; wider anteriorly to thinner, filiform from midbody. Anterior segments short, much wider than long (two to three times); longer and biannulate (length $=$ width) at postbranchial region, then cylindrical, longer than wide.

Prostomium conical, distally rounded, longer than wide, ending in a cylindrical sensorial organ, sometimes everted (Fig. 2A, 3A). Pair of nuchal organs as 

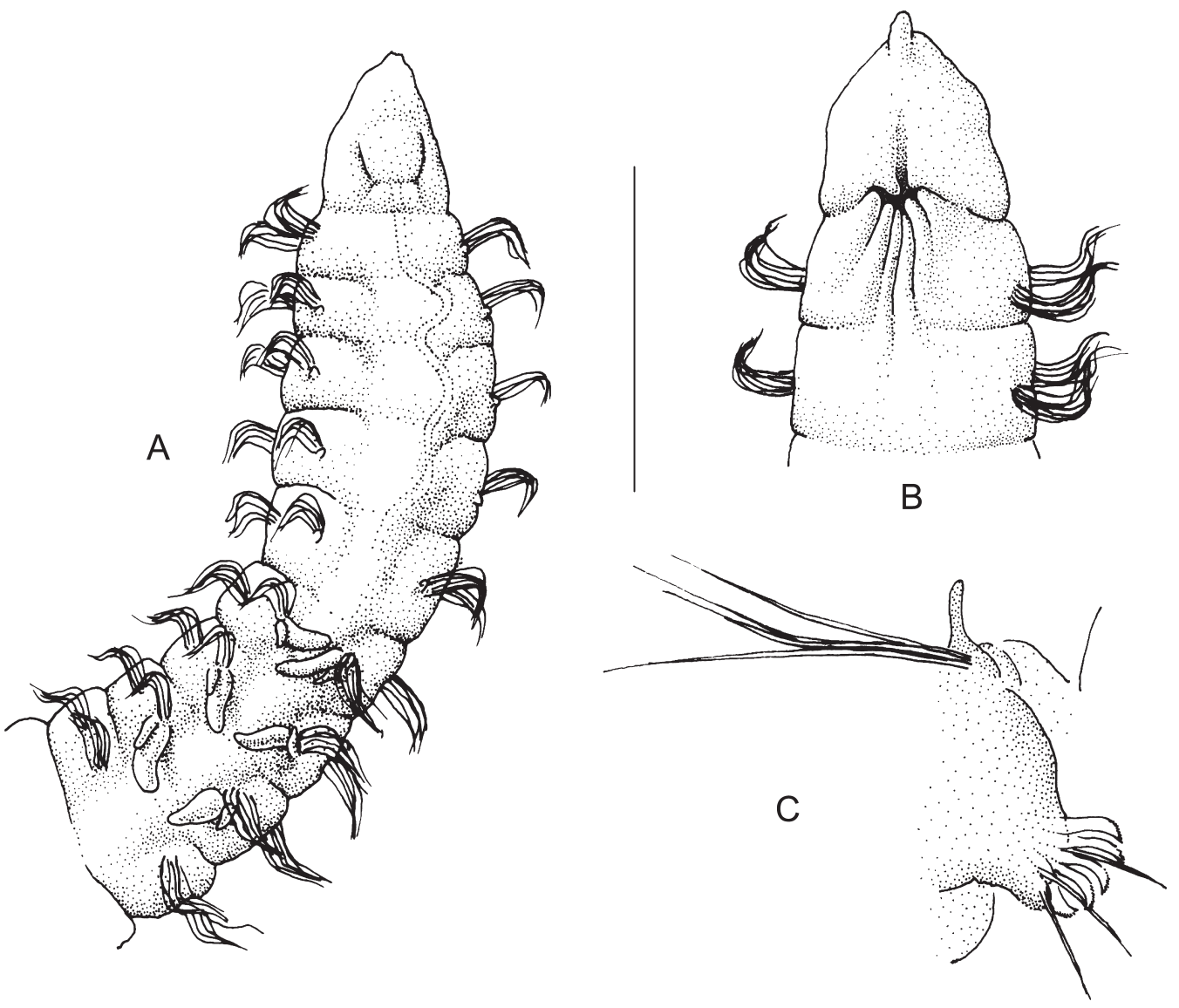

Fig. 2. - Levinsenia flava: A, anterior region, dorsal view; B, anterior region, ventral view; C, parapodium chaetiger 26. Scale bar: A $360 \mu$ m; B $100 \mu \mathrm{m} ; \mathrm{C} 295 \mu \mathrm{m}$.

deep nuchal slits. Yellow-brownish pigmentation on each side of nuchal region (often lost in preserved specimens). Posterior buccal lip with six longitudinal folds, extending to chaetiger 2 (Fig. 2B).

First five notopodial postchaetal lobes (prebranchial) short, rounded tubercles. In branchial segments longer, digitiform, distally rounded, becoming short again and rounded in postbranchial segments. In posterior segments short, but thinner, conical. Neuropodial postchaetal lobes absent (Fig. 2B).

Branchiae always starting from chaetiger 6, 3-5 pairs, very short $(1 / \mathrm{w}=2-4$, mostly $2.5-3.5)$, cirriform, distally rounded, without cilia (Fig. 2A, 3B); first and last usually shorter.

Modified ventral chaetae from chaetiger 1318 (mostly 14-17), as 4-6 sigmoid hooks, strongly curved, arranged in a single row (Fig. 2C, 3C); hooks unidentate, with spinulate tuft on convex side, not reaching chaetal tip, orange-brownish pigmentation in some specimens; with 2-4 fine capillary accompanying chaetae. All other chaetae capillary.

Many specimens with orange-coloured anterior region.
Discussion. Our specimens agree well with the Strelzov (1973) description, the only difference being the number and size of branchiae. However, the original description was based on a single specimen, so the natural variability of the taxon was not reflected. According to Strelzov (1973), Levinsenia flava has three pairs of branchiae with a 1/w of 2.8, and neuropodial hooks present from chaetiger 15 . In our specimens, the number of branchiae varies between 3-5 and 1/w between 2-4 (mostly between 2.5-3.5), while the neuropodial hooks appear mainly from chaetigers 14-17.

Distribution. New Guinea, 1790 m deep. Capbreton Canyon, Bay of Biscay, between 492-1113 m deep. First record for the Atlantic.

\section{Levinsenia gracilis (Tauber, 1879)}

Aonides gracilis, Tauber, 1879: 115.

Paraonis (Paraonis) gracilis, Cerruti, 1909: 468, 498, 504, Fig. g.Pettibone, 1963:301-302, Fig. 79 A-D.

Paraonis gracilis, Uschakov, 1955: 286, Fig. 103 A-B.- Hartman, 1969: 75-76, Fig. 1-3.- Laubier and Ramos, 1974: 1098-1099.Campoy, 1981: 23 . 


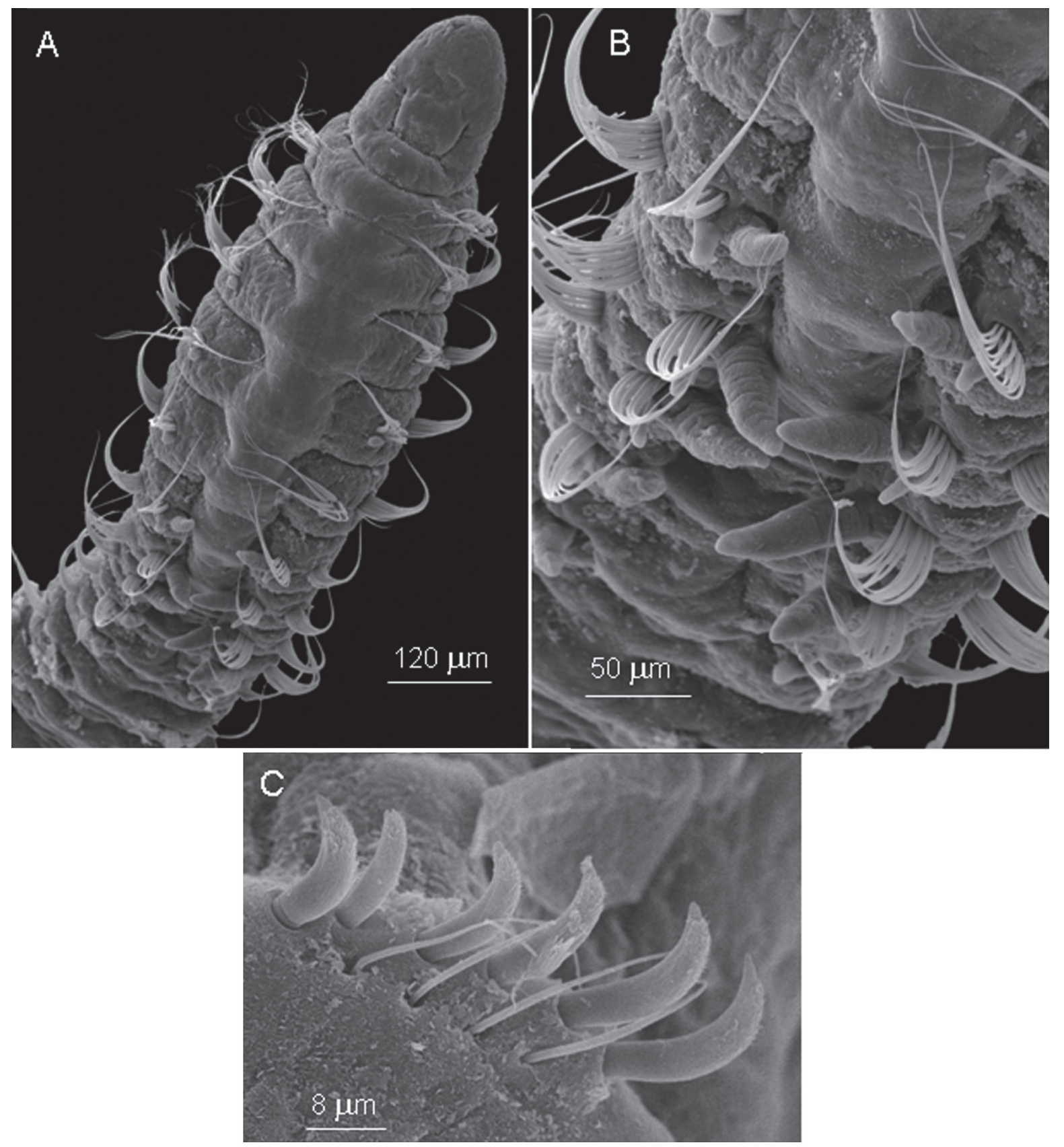

FIG. 3. - Levinsenia flava: A, anterior region, dorsal view; B, branchial region; C, modified neurochaetae. Scale bar: A $120 \mu \mathrm{m}$; B $50 \mu \mathrm{m}$; C $8 \mu \mathrm{m}$.

Tauberia gracilis, Strelzov, 1973: 127-133, Figs. 54 A-F, 55 A-F, 56 A-D, 57 A-E.- Katzmann and Laubier, 1975: 569.

Levinsenia gracilis, Hartley, 1981: 146.- Gaston, 1984: 2-51 - 53

Figs. 2-51, 52 A-C.- Blake, 1996: 33-34, Fig. 2.1 A-D.

Material examined. 36 specimens from Capbreton Canyon, Bay of Biscay, Atlantic Ocean (coordinates in Table 1): CB88/DI12 (2), CB88/DI13 (7), CB88/DI19 (5), CB88/DI21 (1), CB88/DI26 (3), CB88/DI31 (1), CB88/DI33 (13), CB89/KF42 (1), CB89/KF44 (1), CB89/KF52 (1), CB89/KF57 (1).

Discussion. Our specimens (only one complete) agree well with the descriptions by Strelzov (1973) and Blake (1996). They have the prostomium coni- cal, 5-7 (mostly 5-6) prebranchial segments, 10-12 pairs of densely ciliated branchiae (1/w mostly between $3.5-4.5 ; 1=$ mostly between $0.10-0.19 \mathrm{~mm}$; $\max .1=0.19 \mathrm{~mm}$ ), neuropodial unidentate aciculate curved hooks from chaetiger 20-22, and pygidium conical with one pair of anal cirri.

Distribution. Cosmopolitan (Atlantic, Pacific, Indian, and Arctic Oceans, Mediterranean Sea) and eurybathic (from shallow sublittoral to abyssal depths). 


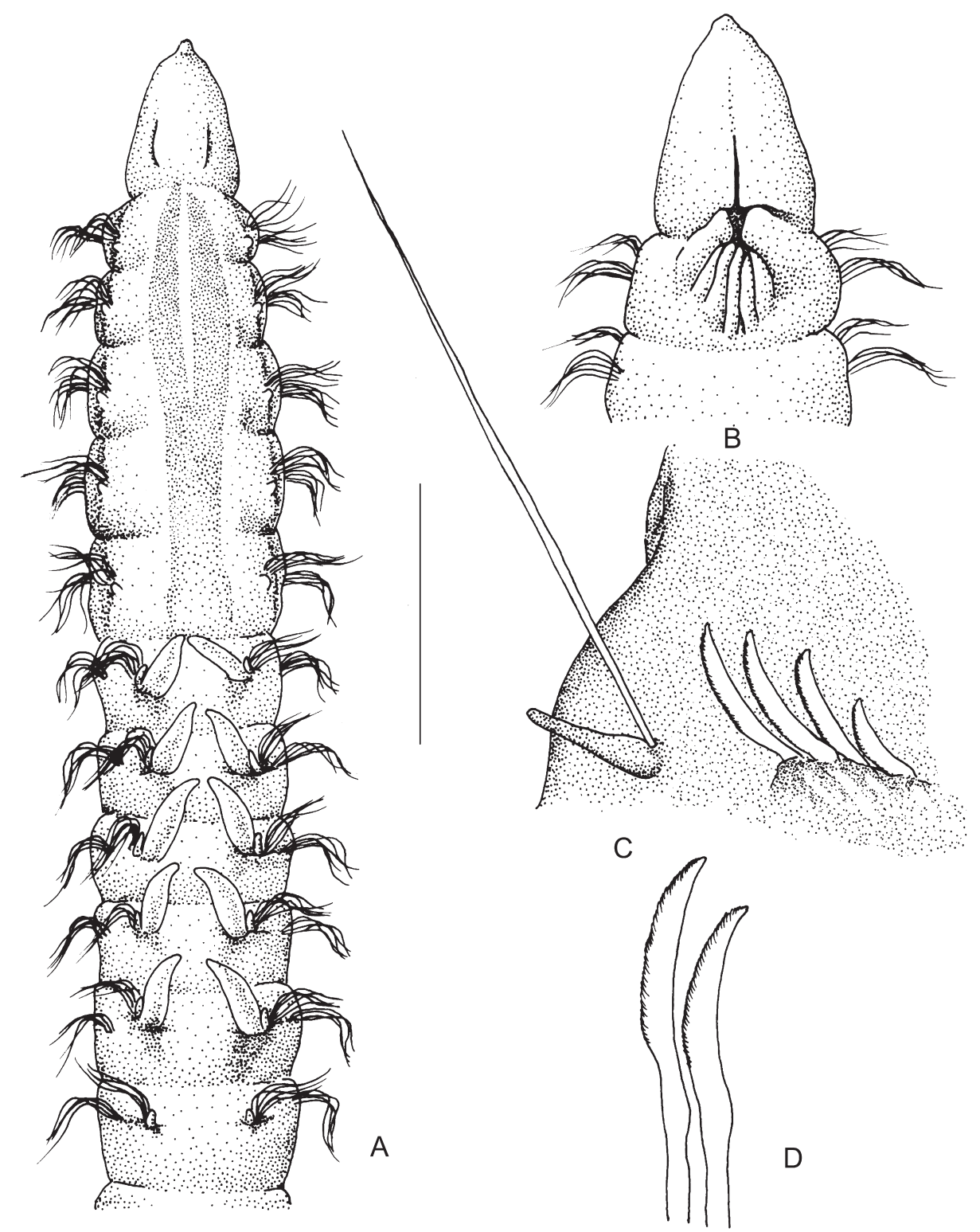

FIG. 4. - Levinsenia kantauriensis n. sp.: A, anterior region, dorsal view; B, anterior region, ventral view; C, parapodium, chaetiger 29; D, modified neurochaetae. Scale bar: A $350 \mu \mathrm{m}$; B $260 \mu \mathrm{m}$; C $50 \mu \mathrm{m}$; D $40 \mu \mathrm{m}$.

Levinsenia kantauriensis n. sp.

(Figs. 4 and 5 )

Material examined. 19 specimens from Capbreton Canyon, Bay of Biscay, Atlantic Ocean (coordinates in Table 1). CB88/DI12 (2), CB88/DI26 (1), CB88/DI31 (3), CB88/DI33: Holotype (MNCN 16.01/11200), one paratype (MNCN 16.01/11201), two paratypes (INSUB POL 331) and 5 specimens, CB88/DI37 (2), CB89/KF38 (1), CB89/KF45 (1).

Description., All specimens incomplete, 0.15$0.25 \mathrm{~mm}$ wide. Holotype maximum width (in branchial region) $0.22 \mathrm{~mm}, 11.7 \mathrm{~mm}$ long for 40 chaetigers.

Body long, slender, wider anteriorly to thinner, filiform from midbody.
Anterior segments short, twice as wide as long; longer in postbranchial region (length = width), then cylindrical, longer than wide.

Prostomium conical, rather longer than wide, ending in a cylindrical sensorial organ, sometimes everted (Fig. 4A, 5A). Pair of nuchal organs as deep nuchal slits. Posterior buccal lip with 6-7 longitudinal folds, extending to chaetiger 2 (Fig. 4B).

First five notopodial postchaetal lobes (prebranchial) short, rounded tubercles; branchial ones longer, digitiform, distally rounded; postbranchial ones again short, rounded, to short, thinner, conical when posterior-most. Neuropodial postchaetal lobes absent (Fig. 4B). 

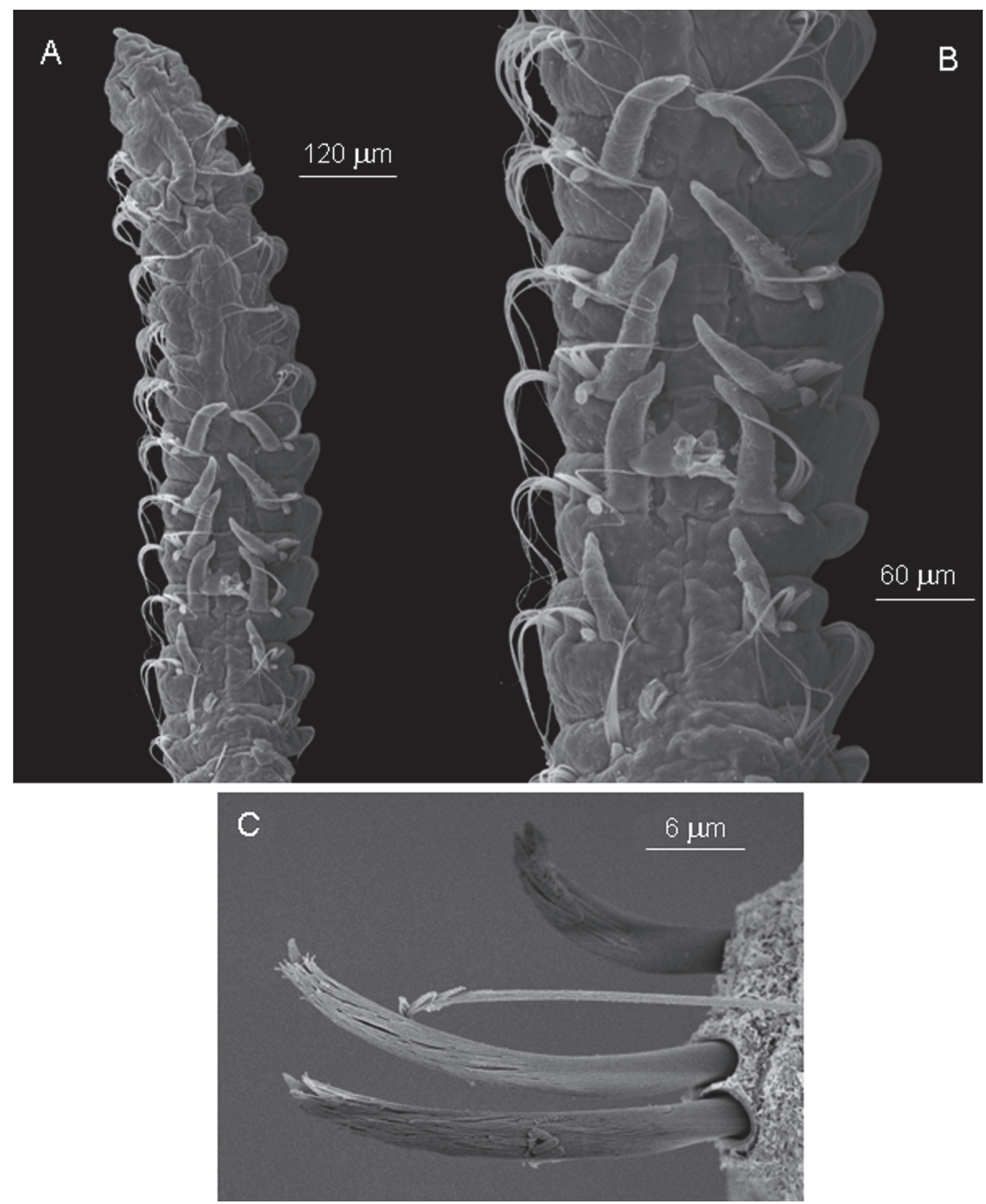

FIG. 5. - Levinsenia kantauriensis n. sp.: A, anterior region, dorsal view; B, branchial region; C, modified neurochaetae. Scale bar: A 120 um; B $60 \mu \mathrm{m} ;$ C $6 \mu \mathrm{m}$.

Branchiae 5-6, starting from chaetiger 6; cirriform, slightly ciliated, with rounded tip ( $1 / \mathrm{w}$ mostly between 2.6-3.5; $1=$ mostly between $0.07-0.10 \mathrm{~mm}$; $\max .1=0.11 \mathrm{~mm})($ Fig. $4 \mathrm{~A}, 5 \mathrm{~A}, \mathrm{~B})$.

Modified neurochaetae from chaetiger 12-16 (mostly from 14-16), up to 6 per fascicle, arranged in a single row (Fig. 4C, 5C). Neurochaeta as aci culate curved hooks projecting clearly from body, with expanded shaft, narrowing to a pointed tip, and a pubescent sheath on convex side of shaft, but not reaching end of chaetae (Fig. 4D, 5C); ventral-most hook more strongly curved than dorsal-most ones (Fig. 4C, 5C); 2-3 fine capillary chaetae accompanying the hooks. All other chaetae capillary. 







\begin{tabular}{|c|c|c|c|c|}
\hline 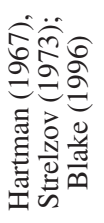 & 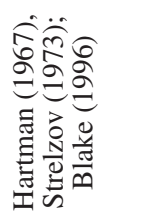 & 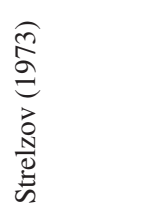 & 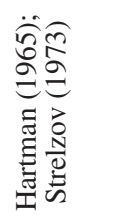 & 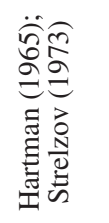 \\
\hline 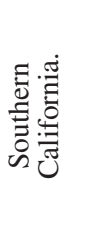 & 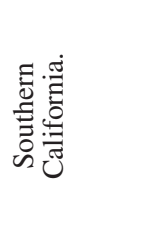 & 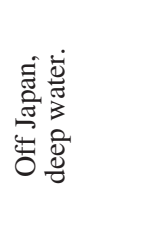 & 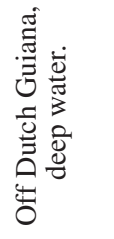 & 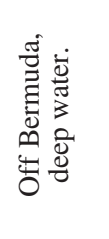 \\
\hline$\stackrel{n}{\sim}$ & $\stackrel{+}{\infty}$ & 兽 & 8 & $\stackrel{+}{n}$ \\
\hline 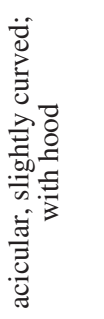 & 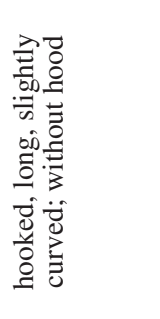 & 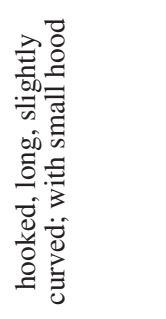 & 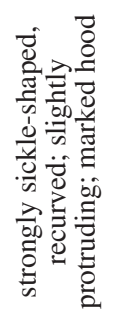 & 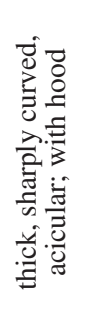 \\
\hline $\begin{array}{l}0 \\
0 \\
\vdots \\
\vdots\end{array}$ & $\begin{array}{l}\hat{0} \\
\hat{3}\end{array}$ & $\begin{array}{l}0 \\
0 \\
\because\end{array}$ & í & $\begin{array}{l}n \\
0 \\
\vdots \\
O\end{array}$ \\
\hline$\stackrel{\infty}{n}$ & $\frac{0}{n}$ & $\frac{\infty}{b}$ & $\frac{\vec{r}}{\stackrel{1}{v}}$ & $\frac{\infty}{m}$ \\
\hline 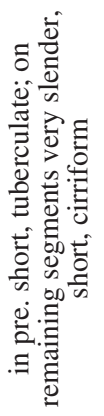 & 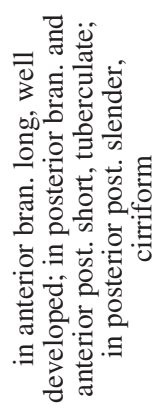 & 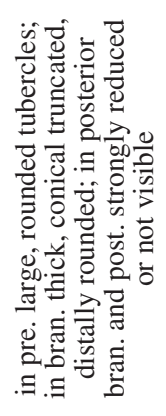 & 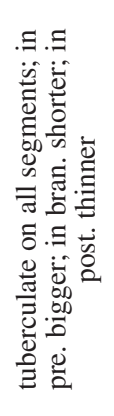 & 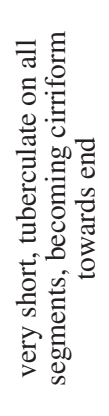 \\
\hline 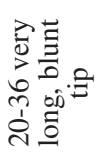 & 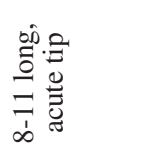 & 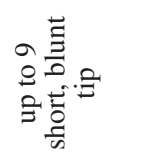 & 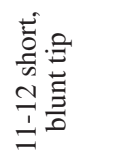 & 0 \\
\hline$n$ & $\begin{array}{l}\infty \\
i \\
i\end{array}$ & $\hat{n}$ & $\hat{b}$ & 1 \\
\hline 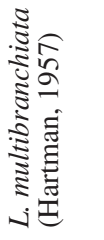 & 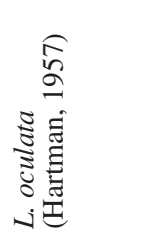 & 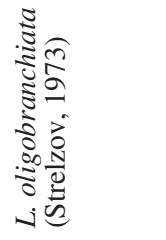 & 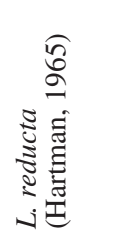 & 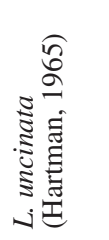 \\
\hline
\end{tabular}

Some specimens with orange-brownish pigmented hooks.

Etymology. The species name refers to the collecting site (Cantabrian Sea $=$ Kantauri Itsasoa, in Basque $)$.

Discussion. With the present new species, the genus Levinsenia includes 15 species and 2 subspecies that are considered valid (Table 2). Three Levinsenia species [L. gracilis, $L$. oligobranchiata (Strelzov, 1973) and L. oculata (Hartman, 1957)] are known to have less than 20 pairs of not very short branchiae; first prebranchial segment between segments 4-8; modified neurochaetae hooked, unidentate; and modified capillary chaetae absent. Levinsenia kantauriensis $\mathrm{n}$. sp. is similar to $L$. gracilis in size and general shape of branchiae and in the modified neurochaetae. However, they differ mainly because the former has less densely ciliated branchiae than the latter. Moreover, L. kantauriensis n. sp. has 5 prebranchial segments, 5-6 branchial pairs and modified neurochaetae appearing mostly from chaetiger $14-16(4-7,10-15$ and $20-26$ in L. gracilis respectively).

Levinsenia kantauriensis $\mathrm{n}$. $\mathrm{sp}$. is distinguished from L. oligobranchiata, which has shorter branchiae and dorsal lobes on the posterior branchial segments, and modified neurochaetae with very poorly developed pubescence on the convex side of the shaft.

Levinsenia oculata differs from L. kantauriensis n. sp. mainly in number, size and shape of branchiae (more numerous, longer and narrower in the former), by the absence of pubescence sheath on the convex side of the shaft of the modified chaetae and by the presence of pigmented spots on the head in L. oculata.

Distribution. Capbreton Canyon, Bay of Biscay, between 492 and 1113 m depth.

Genus Cirrophorus Ehlers, 1908 Cirrophorus branchiatus Ehlers, 1908

(Fig. 6)

Cirrophorus branchiatus, Ehlers, 1908: 124-126, Fig. 5-9.- Day, 1967: 563, Fig. 24.3 A-E.- Laubier, 1966: 469-476.- Glémarec, 1966: 1049-1051, Fig. 1 A.- Strelzov, 1973: 108-111, Fig. 46 A-H.- Campoy, 1981: 21 Fig. 4 A,B.

Material examined. Fifteen specimens from Capbreton Canyon, Bay of Biscay, Atlantic Ocean (coordinates in Table 1). CB88/DI12 (3), CB88/DI13 (2), CB88/ DI26 (6), CB88/DI31 (1), CB88/DI33 (2), CB89/KF42 (1).

Description. All specimens incomplete, measuring 0.3-0.4 mm wide (up to $0.44 \mathrm{~mm}$ ).

Discussion. Our specimens agree well with the descriptions by Glémarec (1966) and Strelzov (1973), as they have the prostomium conical with a short club-shaped single antenna, 8-15 


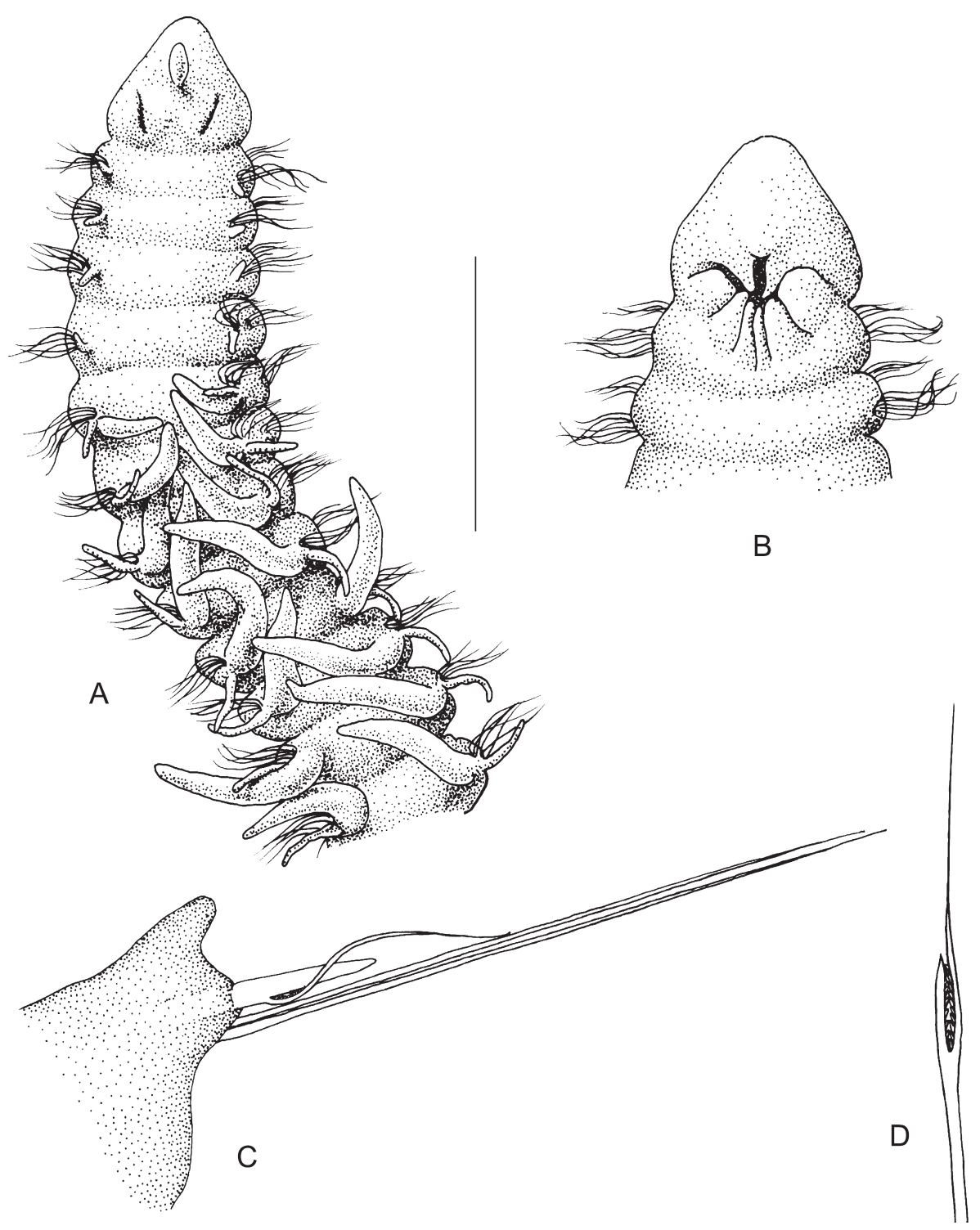

FIG. 6. - Cirrophorus branchiatus: A, anterior region, dorsal view; B, anterior region, ventral view; C, notopodium, chaetiger 21; D, lyriform dorsal modified chaeta, chaetiger 5. Scale bar: A $560 \mu \mathrm{m}$; B $450 \mu \mathrm{m}$; C $70 \mu \mathrm{m}$; D $50 \mu \mathrm{m}$.

pairs of ciliated branchiae $(1 / \mathrm{w}$ mostly between $4-$ $5.5 ; 1=$ mostly between $0.25-0.35 \mathrm{~mm}$; $\max .1=0.39$ $\mathrm{mm}$ ) starting from chaetiger 5 , and dorsal modified chaetae from chaetiger 5-7, first lyriform and then acicular with a long lateral filament (from chaetiger 10-13). In the studied specimens the number of branchial pairs is size dependent.

Distribution. North Atlantic, South Africa, California, Mediterranean, Sea of Japan, Red Sea. Between 8 and 2,780 $\mathrm{m}$ depth.

Genus Paraonides Cerruti, 1909

Paraonides myriamae Katzmann and Laubier, 1975 (Fig. 7)
Paraonides myriamae, Katzmann and Laubier, 1975: 572-575, Fig. $2 \mathrm{~A}-\mathrm{C}$.

Material examined. One specimen from Capbreton Canyon, Bay of Biscay, Atlantic Ocean (coordinates in Table 1). CB88/DI31.

Description. Specimen incomplete, $6.93 \mathrm{~mm}$ long, $0.24 \mathrm{~mm}$ wide for 42 chaetigers. Body thin and filiform, with short, wide anterior segments; more moniliform from midbody.

Prostomium conical, with a terminal sensory organ (Fig. 7A). Nuchal organs as a pair of deep nuchal slits in posterior part of prostomium. Posterior buccal lip with longitudinal folds starting from median part of chaetiger 1 (Fig. 7B).

Branchiae and neuropodial postchaetal lobes ab- 

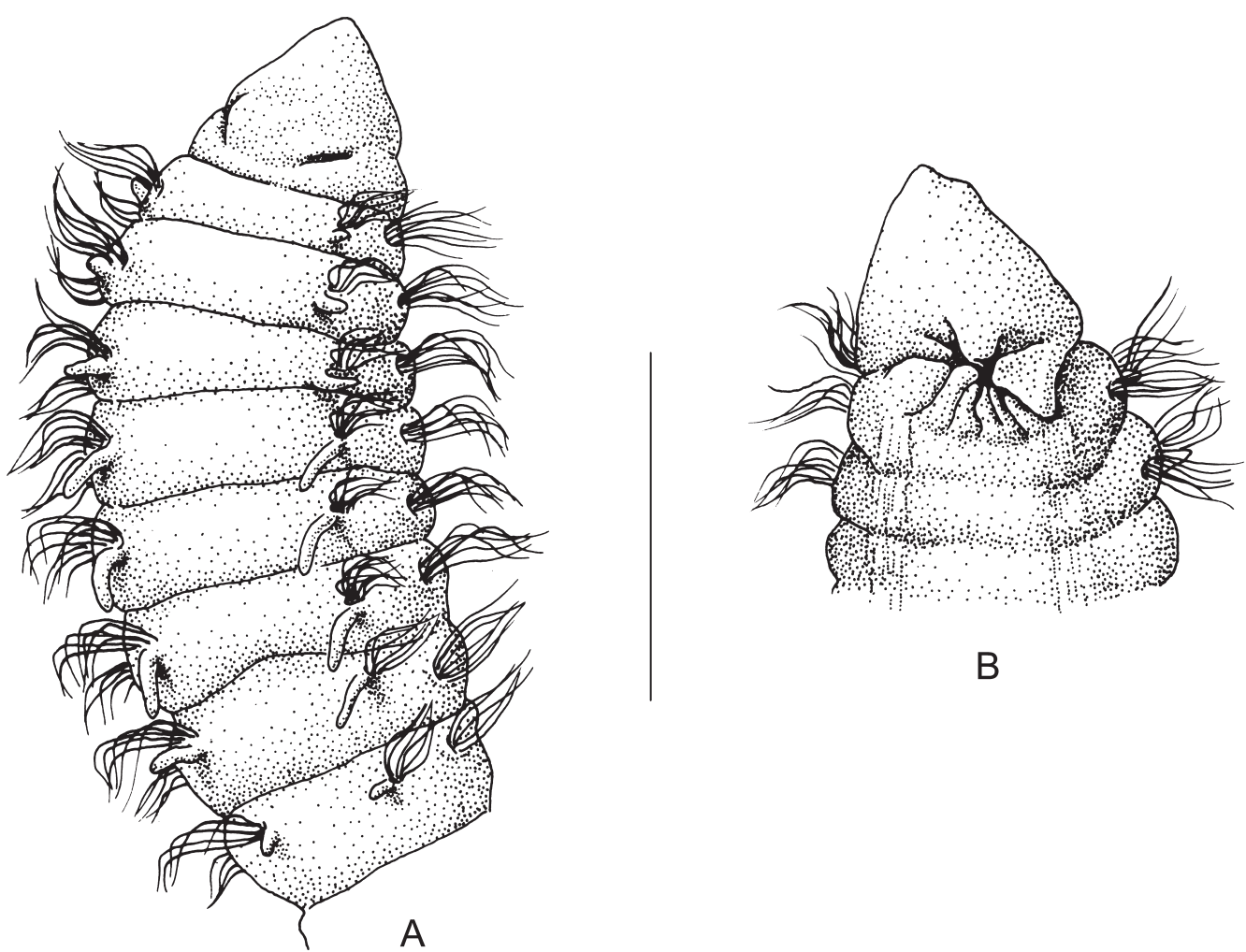

B

FIG. 7. - Paraonides myriamae: A, anterior region, dorsal view; B, anterior region, ventral view. Scale bar: A $265 \mu \mathrm{m}$; B $250 \mu \mathrm{m}$.

sent (Fig. 7A, B).

First notopodial postchaetal lobe very short; 2 nd - 3rd slightly longer; 4th - 7th progressively longer; 8th - 42nd shorter, triangular (Fig. 7A).

All chaetae capillaries; dorsal-most neuropodial one in median and posterior segments longer.

Discussion: The specimen agrees well with the description by Katzmann and Laubier (1975).

Distribution. Adriatic, Capbreton Canyon, Bay of Biscay, 505 to $512 \mathrm{~m}$ depth. First record for the Atlantic.

Genus Paradoneis Hartman, 1965

Paradoneis armata Glémarec, 1966

Paradoneis armata, Glémarec, 1966: 1046-1049, Figs 1 B-C; 2 AC.- Laubier, 1972: 259-262, Fig. 1A-C.

Cirrophorus armatus, Strelzov, 1973: 111-113, Fig. 47 A-E.

Material examined. One specimen from Capbreton Canyon, Bay of Biscay, Atlantic Ocean (coordinates in Table 1). CB89/DI66.

Description. Specimen incomplete, $4.47 \mathrm{~mm}$ long, $0.3 \mathrm{~mm}$ wide (branchial region) for $47 \mathrm{cha}-$ etigers. Prostomium conical, narrowing distally. 17 branchial pairs starting from chaetiger $4(1 / \mathrm{w}$ between 3.75-4; $\max .1=0.16 \mathrm{~mm}$ ). First segments with modified notochaetae lyriform; with typical acicular chaetae from chaetiger 16 .

Discussion. Finding this species in the bathyal region of the Capbreton Canyon seems to confirm the deep-water record made by Amoureux (1982), who reported the species from the continental slope off Brittany, at 1200 meters.

Distribution. Northeast Atlantic (down to $1200 \mathrm{~m}$ depth), Mediterranean (10 to $180 \mathrm{~m}$ depth), Capbreton Canyon, Bay of Biscay (1026 to $1036 \mathrm{~m}$ depth).

Paradoneis drachi Laubier and Ramos, 1974 (Fig. 8)

Paradoneis drachi, Laubier and Ramos, 1974: 1099-1102, Fig. 1 A-D.- Katzmann and Laubier, 1975: 569.

Material examined. One specimen from Capbreton Canyon, Bay of Biscay, Atlantic Ocean (coordinates in Table 1). CB88/DI37.

Description. Specimen incomplete, $3.5 \mathrm{~mm}$ long, $0.22 \mathrm{~mm}$ wide (branchial region) for 41 chaetigers.

Prostomium conical, as long as wide. Median antenna absent (Fig. 8A). One pair of nuchal organs as 

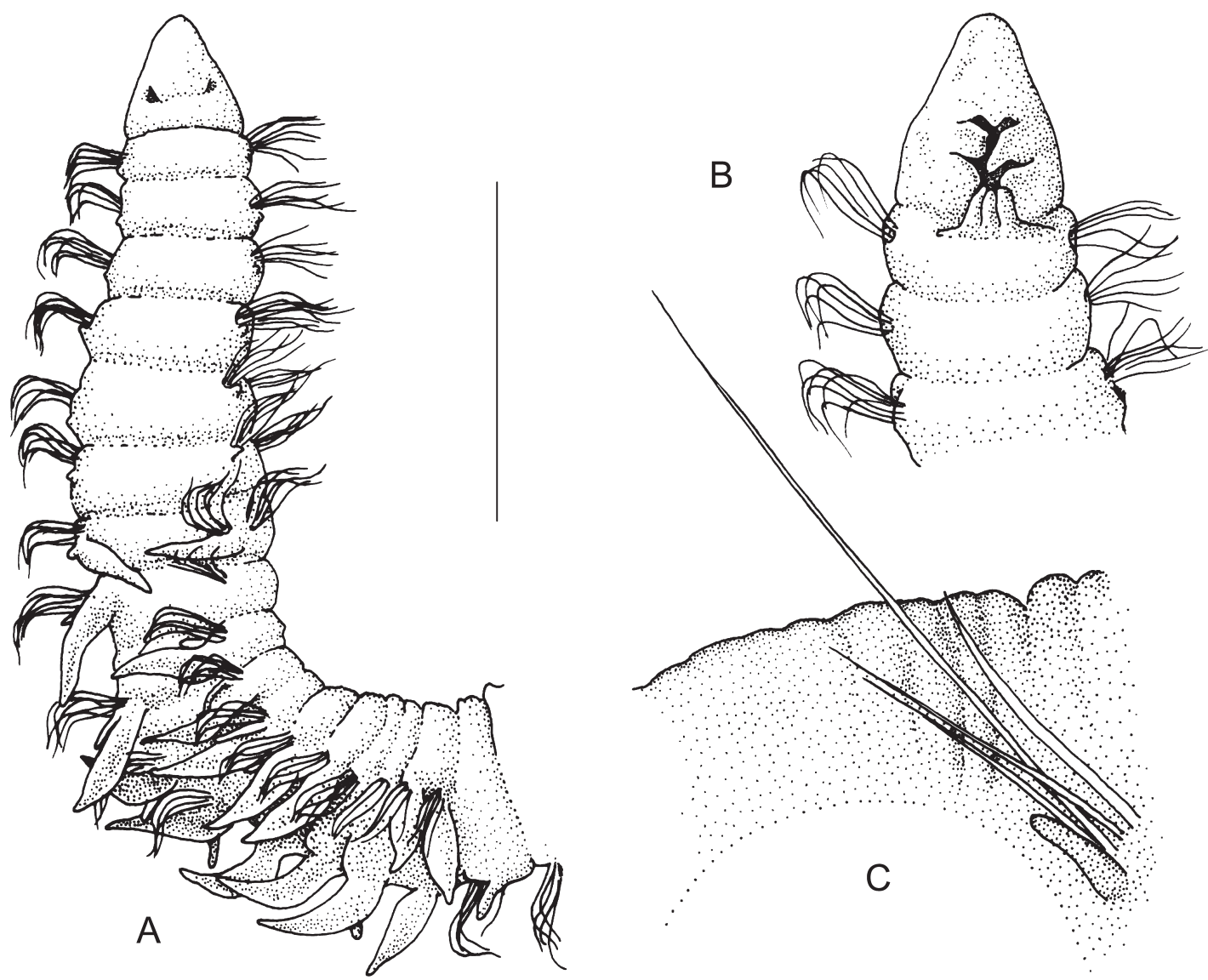

FIG. 8. - Paradoneis drachi: A, anterior region, dorsal view; B, anterior region, ventral view; C, notopodium, chaetiger 36. Scale bar: A 405 $\mu \mathrm{m} ; \mathrm{B} 265 \mu \mathrm{m}$; C $65 \mu \mathrm{m}$.

slits in posterior part of prostomium. Posterior buccal lip with longitudinal folds starting from anterior part of chaetiger 1 (Fig. 8B).

Branchiae, 10 pairs, wide, distally pointed, present from chaetiger 7 (1/w between 3.25-3.7; max. $1=0.13 \mathrm{~mm}$ ); first and last pairs shorter (Fig. 8A).

Prebranchial notopodial postchaetal lobes short, ovoid; branchial long, cirriform; postbranchial short, triangular. Neuropodial postchaetal lobes absent (Fig. 8B).

From chaetiger 36, 1-2 notopodial modified chaetae, acicular, straight, ending in a smooth point (Fig. 8C).

Discussion. Paradoneis spinifera (Hobson, 1972) and Paradoneis drachi are characterized by having smooth acicular spines as modified notopodial chaetae, but differ in number of prebranchial chaetigers (4-5 and 6 respectively). Although Blake (1996) stated that both species could be the same, the specimen from Capbreton agrees well with the description of Laubier and Ramos (1974) and is here considered as P. drachi.
Distribution. Western Mediterranean - Rosas Bay, $115 \mathrm{~m}$ depth, Adriatic, 525 to $530 \mathrm{~m}$ depth. Capbreton Canyon, Bay of Biscay, 508 to $576 \mathrm{~m}$ depth. First record for the Atlantic.

Paradoneis eliasoni Mackie, 1991 (Fig. 9)

Paradoneis eliasoni, Mackie, 1991: 152-154, Fig. 3B-C, 4 A-F, Fig. 5 , Table 2 .

Material examined. 3 specimens from Capbreton Canyon, Bay of Biscay, Atlantic Ocean (coordinates in Table 1). CB88/DI19 (1), CB88/DI26 (1), CB89/KF57 (1).

Description. Two anterior fragments and one almost complete specimen, $0.21-0.27 \mathrm{~mm}$ wide, 2.8-5.9 mm long for 28-55 chaetigers. Body slender, cylindrical, coiled when preserved.

Prostomium conical, rather longer than wide (Fig. 9A). Pair of nuchal organs as deep nuchal slits. Posterior buccal lip with two large tongue-shaped folds starting from buccal segment, and several narrower, longitudinal folds starting from first chaetiger (Fig. 9B). 

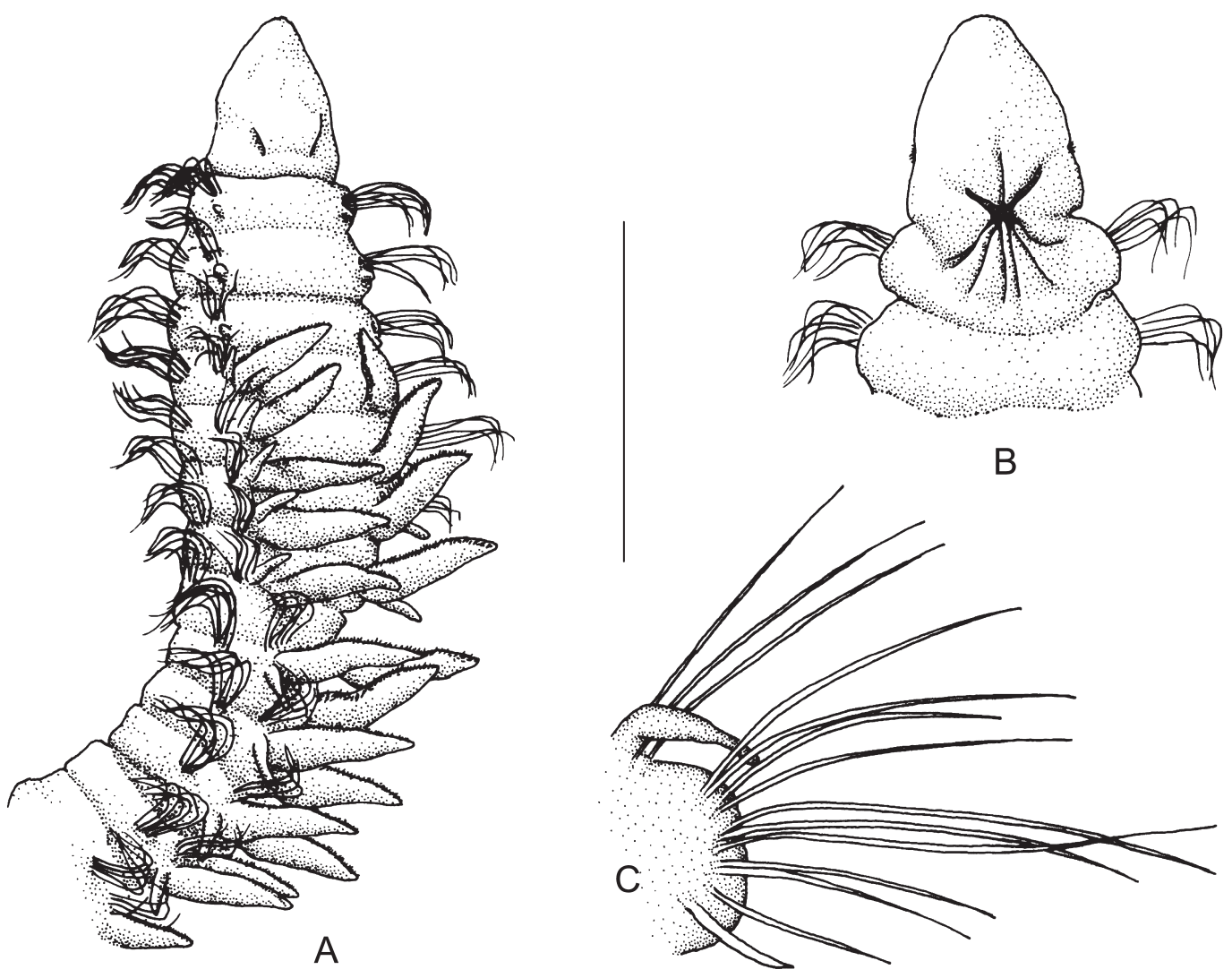

FIG. 9. - Paradoneis eliasoni: A, anterior region, dorsolateral view; B, anterior region, ventral view; C, parapodium, chaetiger 50. Scale bar: A $405 \mu \mathrm{m}$; B $365 \mu \mathrm{m} ;$ C $110 \mu \mathrm{m}$.

First three notopodial postchaetal lobes short, rounded tubercles; on branchial region, more than two times longer, digitiform, distally rounded (Fig. 9A); on postbranchial region, similar in length but slightly more slender and pointed.

Branchiae from chaetiger 4, 10 pairs, ciliated, wide, foliaceous, distally pointed ( $1 / \mathrm{w}$ mostly between 3.3 and $4 ; 1=$ mostly between 0.11 and 0.16 $\mathrm{mm}$; $\max .1=0.16 \mathrm{~mm}$ ).

Anterior dorsal and ventral chaetae as limbated capillaries; with 1-3 lyriform notopodial chaetae with tines similar in thickness but differing in length, with inner edges spinulate, present from chaetiger $4-8$, absent in many chaetigers; with a single ventral curved neuropodial hook on posterior segments (Fig. 9C).

Discussion. The studied specimens agree well with the description by Mackie (1991).

Distribution. Ørensund, Skagerrak, North Sea, Barents Sea. 110 to $681 \mathrm{~m}$ depth. Bay of Biscay. 952 to $1029 \mathrm{~m}$ depth, which confirms that $P$. eliasoni is also a deep-water species (Mackie, 1991).
Paradoneis bathyilvana n. sp. (Figs. 10 and 11)

Material examined. Three specimens from Capbreton Canyon, Bay of Biscay, Atlantic Ocean (coordinates in Table 1). CB88/DI33 (1), CB88/DI37: Holotype (MNCN 16.01/11202) and one paratype (MNCN 16.01/11203).

Description. Only one complete specimen; 0.15-0.19 mm wide. Holotype maximum width (in branchial region) $0.17 \mathrm{~mm}, 7.5 \mathrm{~mm}$ long for 66 chaetigers. Body long, cylindrical, slightly widened anteriorly, slender and moniliform from midbody.

Prostomium conical, rather longer than wide, distally rounded (Fig. 10A, 11B). One pair of nuchal organs as deep slits; behind them, each lateral side of peristomium brown coloured. Posterior buccal lip with longitudinal folds starting from chaetiger 1 (Fig. 10B).

Notopodial postchaetal lobes short, conical, of similar size, long and filiform in last chaetigers (Fig.10A, 11B). Neuropodial postchaetal lobes absent (Fig. 10B).

Branchiae starting from chaetiger 5, 7-8 pairs, cylindrical, distally rounded (1/w mostly between 3 

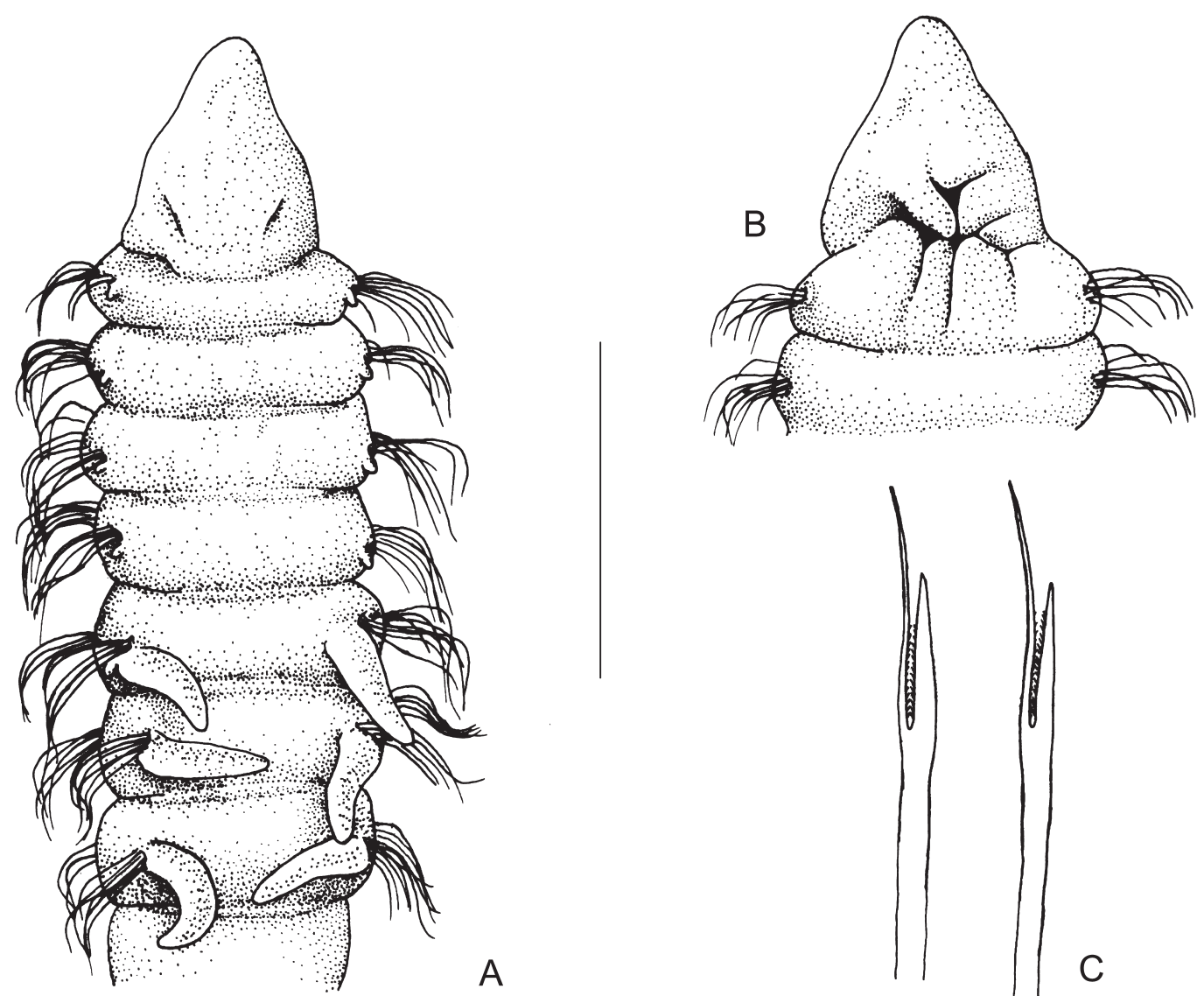

A

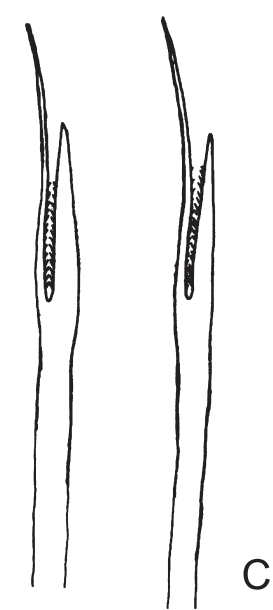

FIG. 10. - Paradoneis bathyilvana n. sp.: A, anterior region, dorsal view; B, anterior region, ventral view; C, lyriform dorsal modified chaetae, chaetigers 14 and 24. Scale bar: A $260 \mu \mathrm{m}$; B $225 \mu \mathrm{m}$; C $40 \mu \mathrm{m}$.

and $3.5 ; 1=$ mostly between 0.07 and $0.11 \mathrm{~mm}$; max. $1=0.11 \mathrm{~mm})$ (Fig. 10A, 11A,B).

Notopodial modified lyriform chaetae starting from chaetiger 5, numbering 2-3, with both tines of similar thickness but unequal length, one longer with thin filamentous tip, inner edges spinulate; one tine becoming much thicker and robust from chaetiger 10-11 (Fig. 10C, 11C). All other chaetae capillary, ventral ones finer and longer than dorsal ones.

Pygidium with three anal cirri of similar size: two dorso-lateral and one mid-ventral.

Etymology. The name of the species refers to its similarity to Paradoneis ilvana, combined with its different bathymetrical range.

Discussion. With the species described in the present paper, the genus Paradoneis includes 17 described species and 2 subspecies (Table 3). Paradoneis bathyilvana n. sp. is similar to Paradoneis ilvana Castelli, 1985, but is smaller and has fewer branchial pairs (7-8 vs. 11-13 respectively) starting at chaetiger 5 instead of 4 .
Distribution. Capbreton Canyon, Bay of Biscay, between 492 and $576 \mathrm{~m}$ depth.

Paradoneis mikeli n. sp.

(Figs. 12 and 13)

? Paradoneis lyra, Katzmann and Laubier, 1975: 569-572, Fig.1
A-C (in part).

Material examined. 96 specimens from Capbreton Canyon, Bay of Biscay, Atlantic Ocean (coordinates in Table 1). CB88/DI12 (3), CB88/DI13 (1), CB88/DI26 (2), CB88/DI31: Holotype (MNCN 16.01/11204), one paratype (MNCN 16.01/11205), two paratypes (INSUB POL 332) and 82 specimens, CB88/DI33 (3), CB89/KF45 (1).

Description. Only three complete specimens, $0.19-0.58 \mathrm{~mm}$ wide. Holotype maximum width (in branchial region) $0.33 \mathrm{~mm}, 13.31 \mathrm{~mm}$ long for 66 chaetigers. Body long, anteriorly wider, cylindrical, becoming slender moniliform from midbody.

Prostomium conical, distally rounded (Fig. 12A, 13B). Pair of nuchal organs as deep nuchal slits, with peristomium lateral brownish coloured behind. Posterior buccal lip with 4-5 narrower longitudinal folds starting at chaetiger 1 (Fig. 12B). 

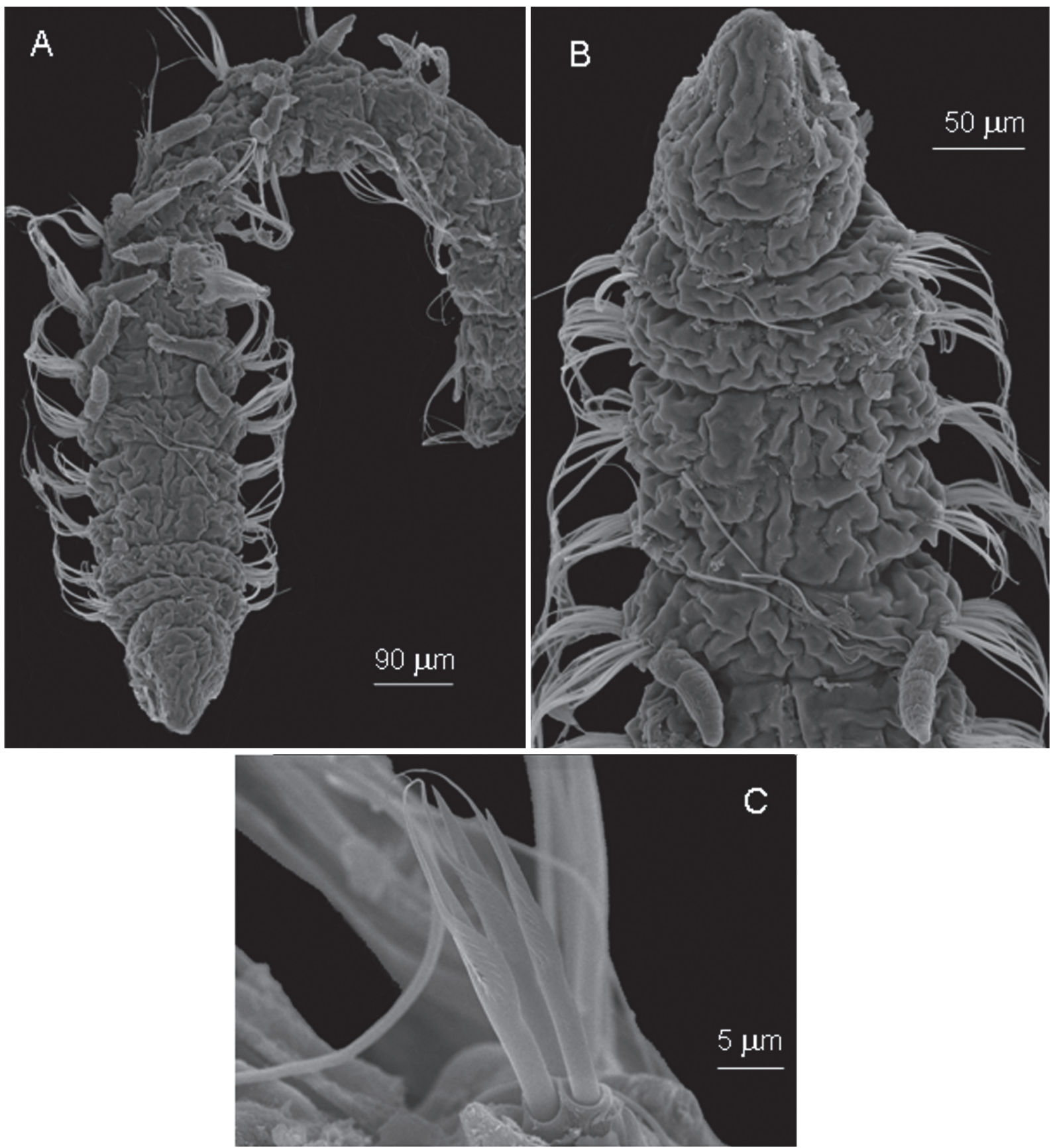

Fig. 11. - Paradoneis bathyilvana n. sp.: A, dorsal view; B, anterior region, dorsal view; C, lyriform dorsal modified chaetae, posterior chaetiger. Scale bar: A $90 \mu \mathrm{m}$; B $50 \mu \mathrm{m}$; C $5 \mu \mathrm{m}$.

First four notopodial postchaetal lobes (prebranchial) short, conical-triangular, lengthening up to chaetiger 4; from chaetiger 5 (first branchial) longer, digitiform to slightly shorter, triangular in postbranchial region (Fig. 12F, 13D); longer, thinner, cirriform when posterior-most (Fig. 12C). Neuropodial postchaetal lobes absent (Fig. 12B).

Branchiae from chaetiger 5, up to 12 pairs in largest individuals, cylindrical, distally rounded, always shorter than interbranchial width (1/w mostly between $3-4 ; 1=$ mostly between 0.07 and $0.11 \mathrm{~mm}$; $\max .1=0.12 \mathrm{~mm})($ Fig. 12A, 13A-C).

Postbranchial segments triannulated, with one mid-dorsal fold (Fig. 12F, 13D).

Notopodial modified lyriform chaetae from chaetiger 4-6, 2-4 all along median and posterior region, decreasing in posterior-most segments, absent from 2-3 posterior-most chaetigers; both tines similarly thick, one short, one long with thin filamentous tip, 


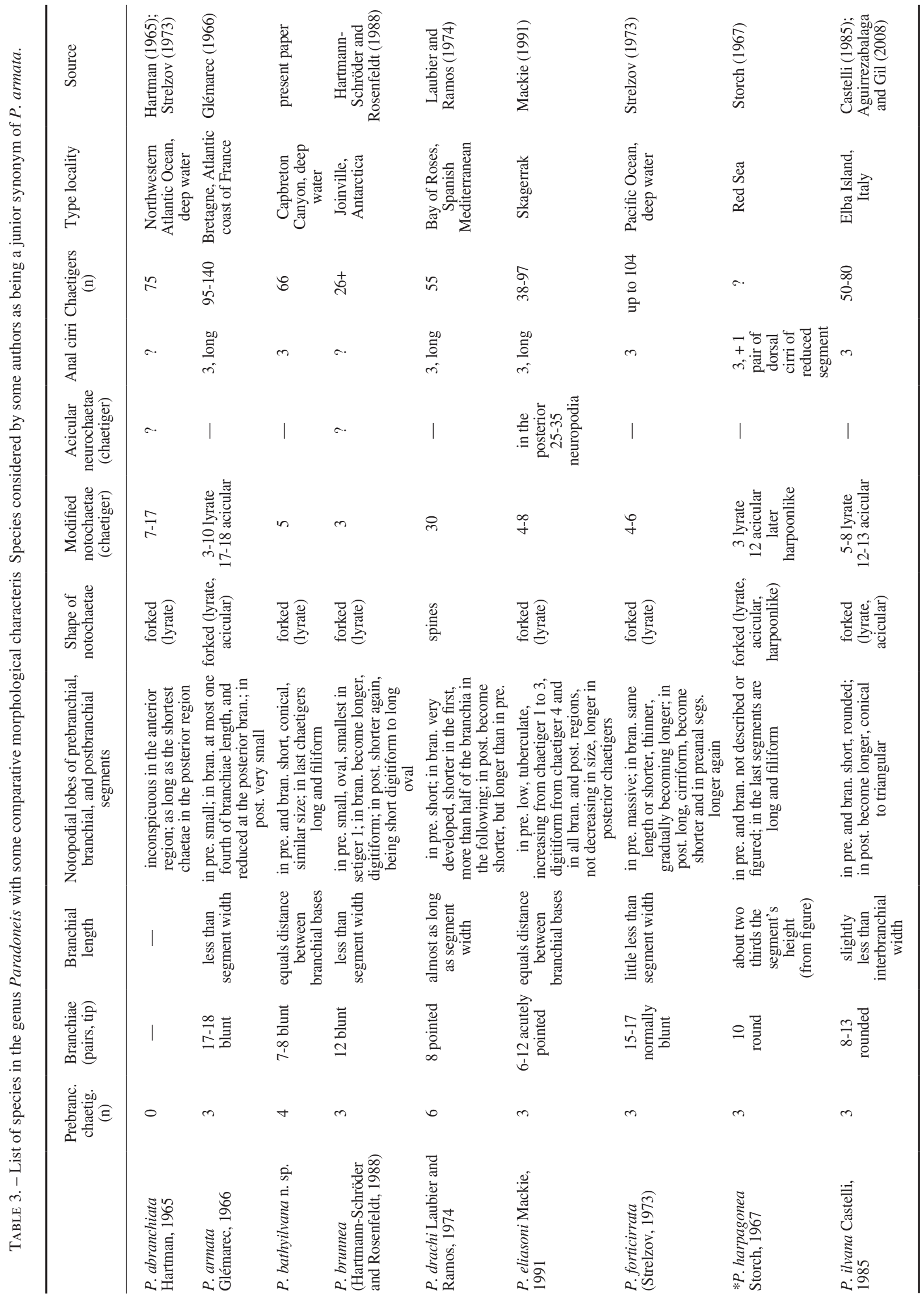




\begin{tabular}{|c|c|c|c|c|c|c|c|c|c|}
\hline 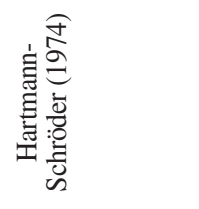 & 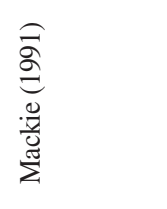 & 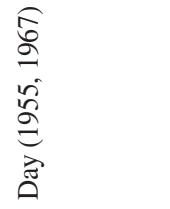 & 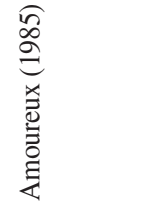 & 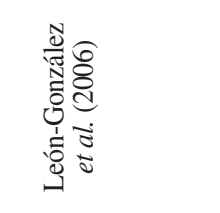 & 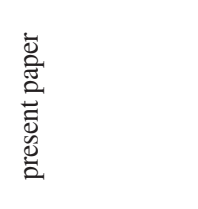 & 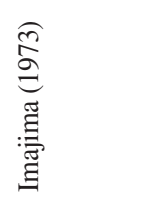 & 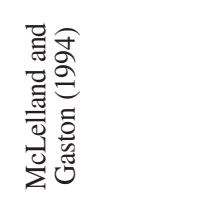 & 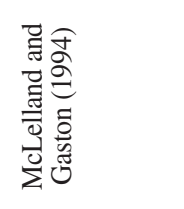 & 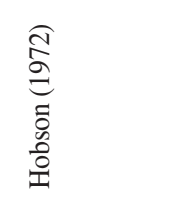 \\
\hline 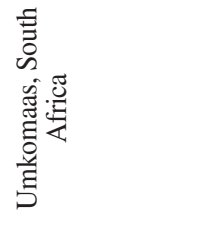 & 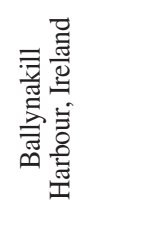 & 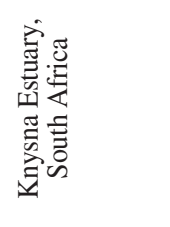 & 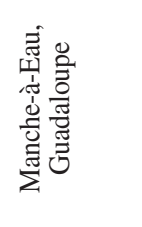 & 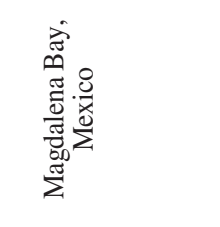 & 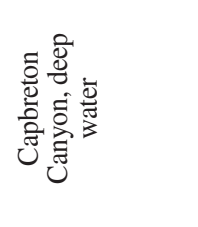 & 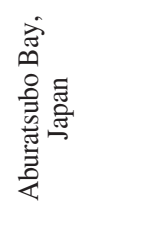 & 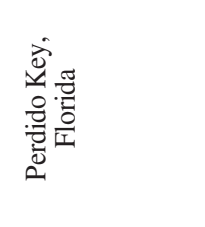 & 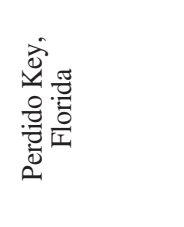 & 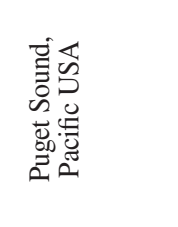 \\
\hline ల్లి & $\frac{8}{\frac{1}{m}}$ & $\triangleright$ & $\frac{+}{0}$ & $\stackrel{+}{n}$ & 8 & ț & ₹े & $\hat{\widetilde{d}}$ & $\mathbb{N}$ \\
\hline 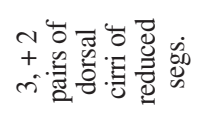 & $\begin{array}{l}\frac{5}{5} \\
\text { on } \\
\text { m }\end{array}$ & $\sigma$. & $a$. & 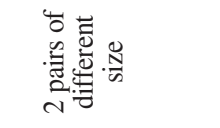 & $m$ & $m$ & 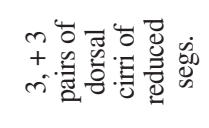 & 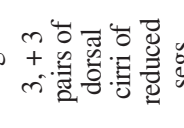 & $\dot{0} \mathrm{~m}$ \\
\hline I & I & $a$. & $a$. & | & 1 & I & I & 1 & | \\
\hline$\nabla$ & 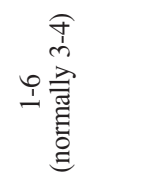 & 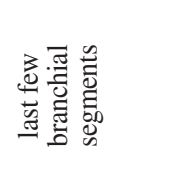 & $m$ & 0 & $\stackrel{0}{+}$ & N & $n$ & $\sim$ & 鄢 \\
\hline 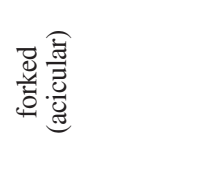 & 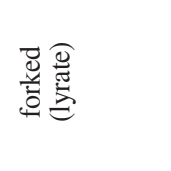 & 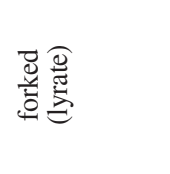 & 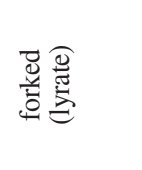 & 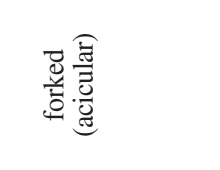 & 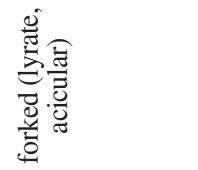 & 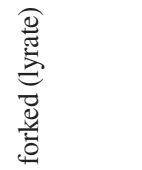 & 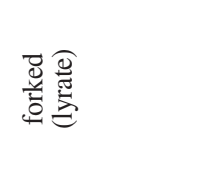 & 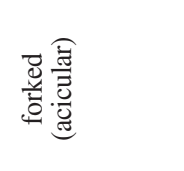 & 苛 \\
\hline 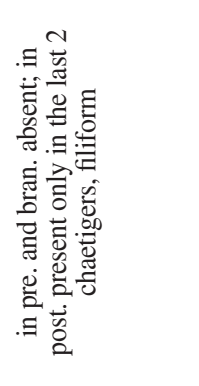 & 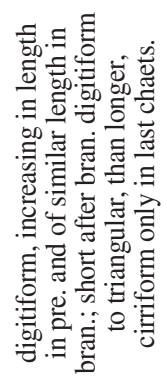 & 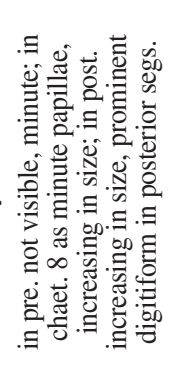 & 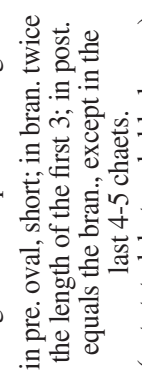 & 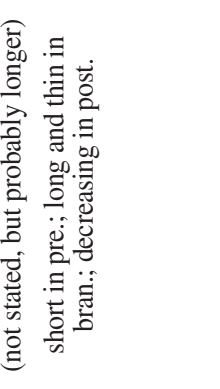 & 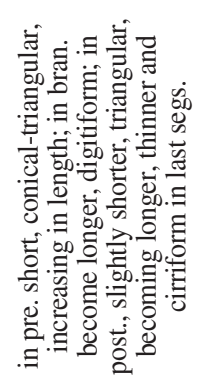 & 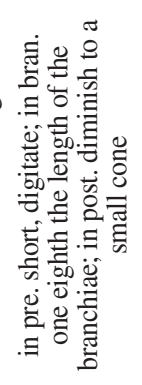 & 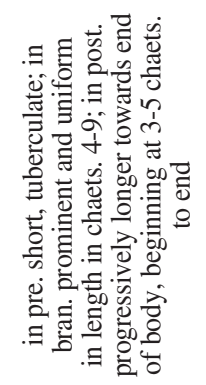 & 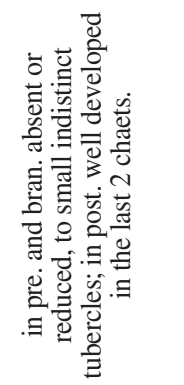 & 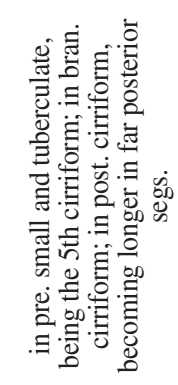 \\
\hline 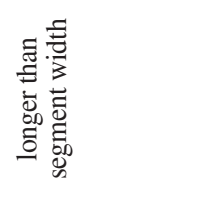 & 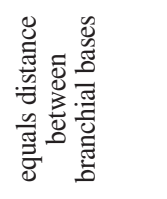 & 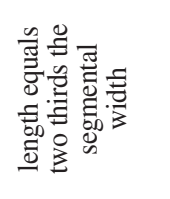 & 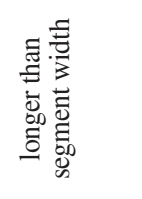 & 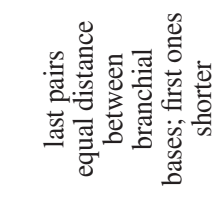 & 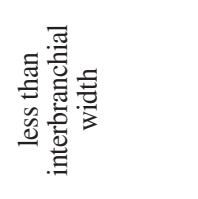 & 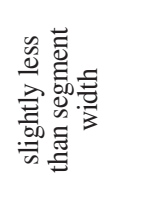 & 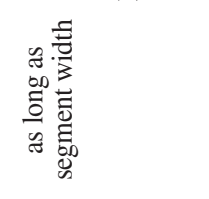 & 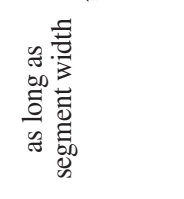 & 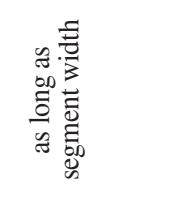 \\
\hline$-\frac{\vec{g}}{\underline{\underline{E}}}$ & 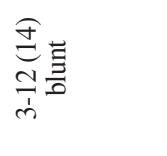 & 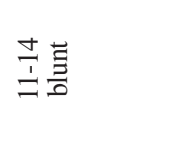 & $\stackrel{I}{ \pm}$ & 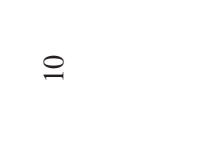 & 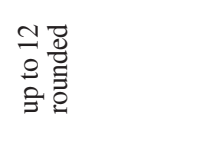 & 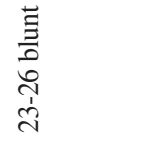 & 岀言 & 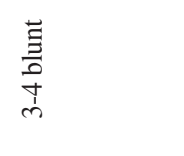 & 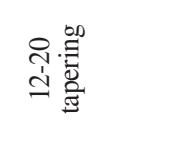 \\
\hline$m$ & $m$ & $m$ & $n$ & $\nabla$ & $\nabla$ & $m$ & $m$ & $n$ & in \\
\hline 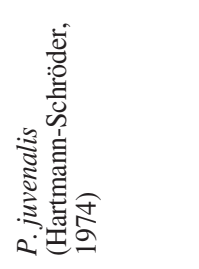 & 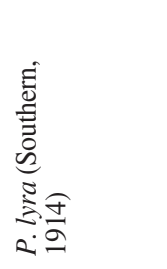 & 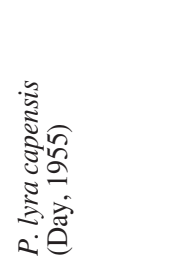 & 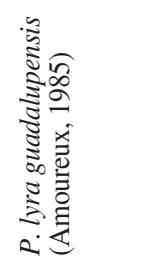 & 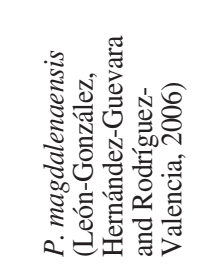 & 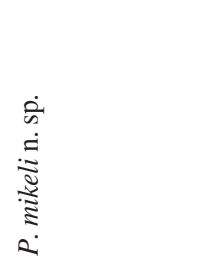 & 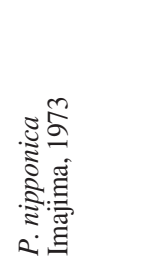 & 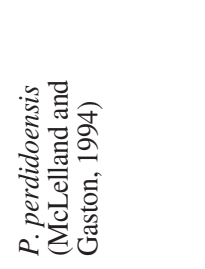 & 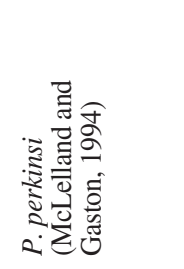 & 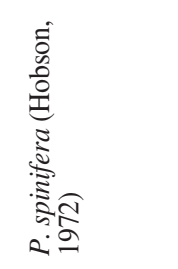 \\
\hline
\end{tabular}




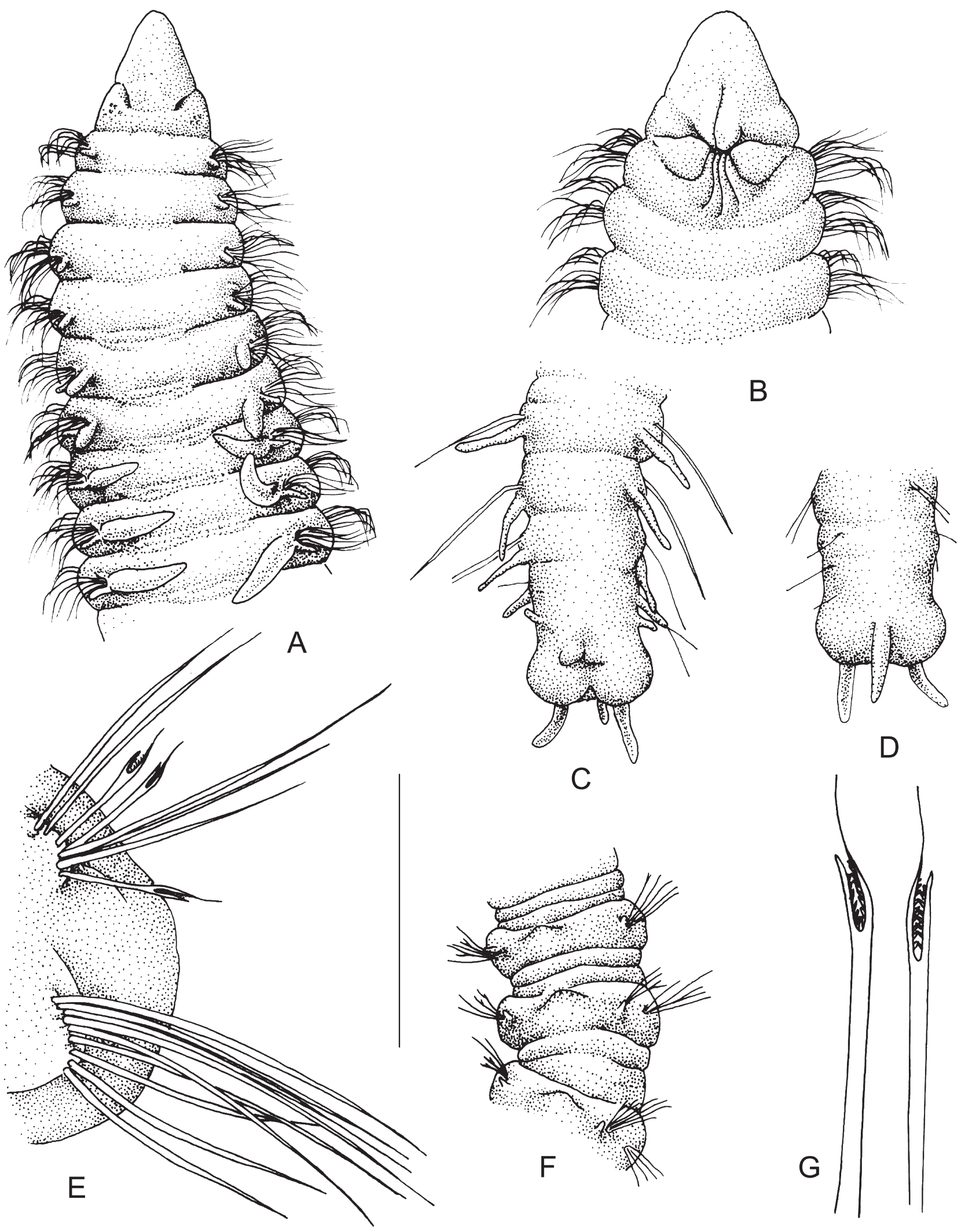

FIG. 12. - Paradoneis mikeli n. sp.: A, anterior region, dorsal view; B, anterior region, ventral view; C, posterior end, dorsal view; D, posterior end, ventral view; E, parapodium, chaetiger 31; F, postbranchial region, chaetigers 17-19, showing mid-dorsal folds; G, lyriform dorsal modified chaetae, chaetiger 31. Scale bar: A $590 \mu \mathrm{m}$; B $325 \mu \mathrm{m}$; C $250 \mu \mathrm{m}$; D $250 \mu \mathrm{m}$; E $100 \mu \mathrm{m}$; F $500 \mu \mathrm{m}$; G $40 \mu \mathrm{m}$. 

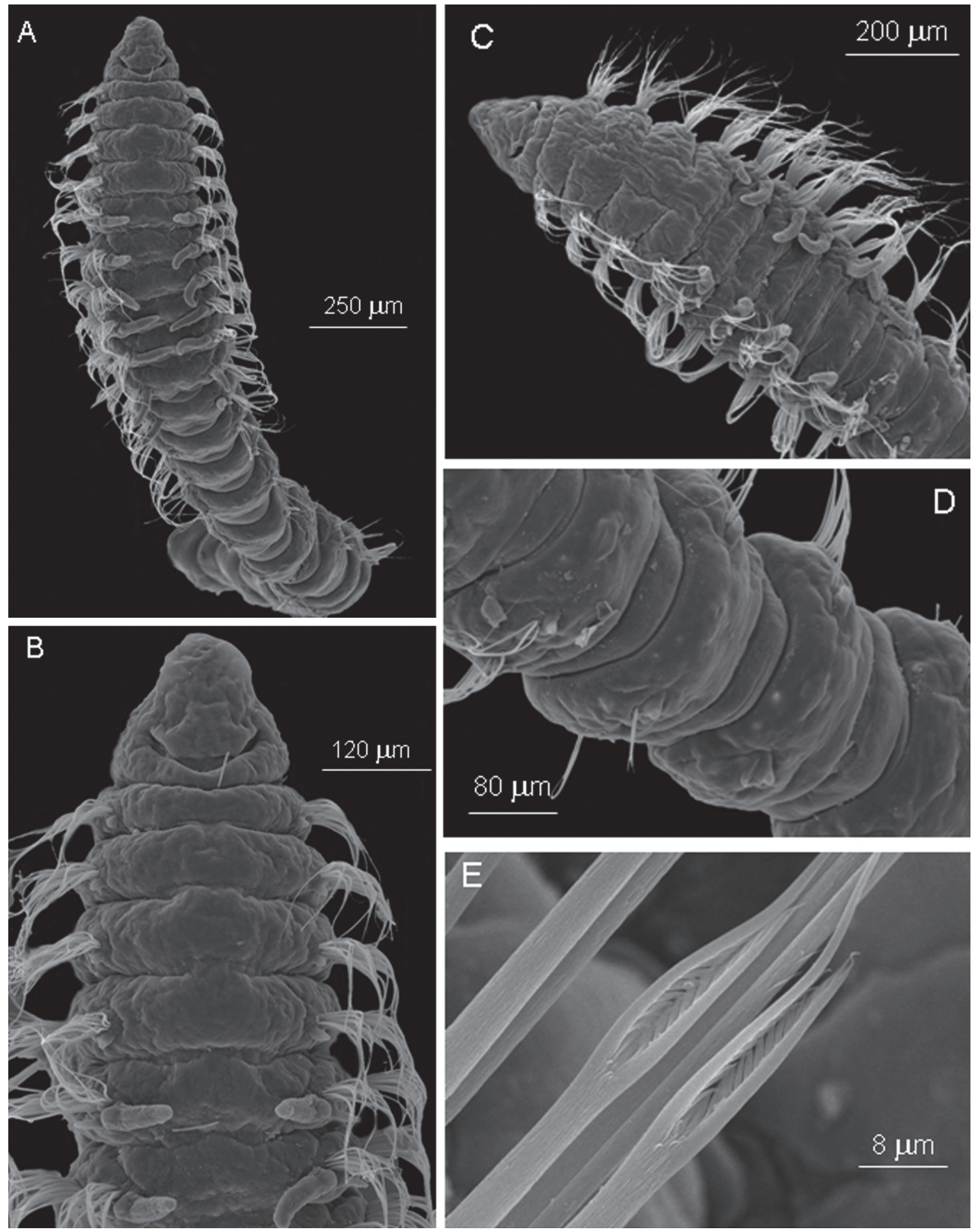

FIG. 13. - Paradoneis mikeli n. sp.: A, dorsal view; B, anterior region, dorsal view; C, anterior region, dorsal view; D, postbranchial region, dorsal view, showing mid-dorsal folds; E, posterior modified neurochaetae. Scale bar: A $250 \mu \mathrm{m}$; B $120 \mu \mathrm{m}$; C $200 \mu \mathrm{m}$; D $80 \mu \mathrm{m}$; E $8 \mu \mathrm{m}$.

both with inner edges spinulate (Fig. 12E,G, 13E). All other chaetae capillary.

Pygidium with two big spherical lobes, anus opening dorsally, and two mid-lateral cirri and one mid-ventral cirrus similar in size (Fig. 12C, D).
Etymology. This species is fondly dedicated to Mikel Agirrezabalaga Arraras.

Discussion. Paradoneis mikeli n. sp. is compared with other species of the genus in Table 3. The 
specimens are very similar to Paradoneis lyra, but differ in having branchiae starting from chaetiger 5 , with the single exception of the right side of one specimen, where they start at chaetiger 4 (Fig. 13C). Paradoneis lyra always has the branchiae starting at chaetiger 4 according to Mackie (1991), who redescribed the species. However, this is not the case in some deep-water records of Paradoneis lyra, in which branchiae were reported to start at chaetiger 5. Pettibone (1963), in a collection of specimens from 1 to 1060 fathoms depth (1.8 to $1939 \mathrm{~m})$, reported branchiae starting at chaetigers 4-5. In turn, all specimens collected by Amoureux (1982) from 500 to $2,000 \mathrm{~m}$ depth had branchiae starting at chaetiger 5, and Katzman and Laubier (1975) collected Mediterranean specimens with branchiae starting both at chaetigers 4 (40\% of individuals) and $5(60 \%$ of individuals) from 20 to $760 \mathrm{~m}$ depth. Although in some of the reported cases it is not possible to determine the exact bathymetric distribution of the two forms, we suggest that the form with 4 prebranchial chaetigers could be of deeper origin, thus corresponding to the new species described here.

Furthermore, branchiae are short (body width/ branchial length $>1.4$ in most of the specimens), always shorter in P. mikeli n. sp. than in P. lyra, and never approximately equal to distance between branchial bases (Mackie, 1991). In addition, the typical subdermal brown eyes of $P$. lyra are absent in $P$. mikeli n. sp., and the number of lyriform chaetae is maintained until the last preanal segment (3-4 in the postbranchial region). Other differences are the presence of a fold in the mid-dorsum of the postbranchial segments and the bilobed pygidium with ventrally opening anus in P. lyra (Katzmann and Laubier, 1975), compared to dorsally opening in $P$. mikeli $\mathrm{n}$. sp.

Paradoneis mikeli n. sp. is like P. bathyilvana n. sp., another deep-sea species, in having 4 prebranchial chaetigers.

Distribution. ? Mediterranean, ? Adriatic, ? off northeast America, ? off Brittany. Capbreton Canyon (Bay of Biscay), 492 to $1113 \mathrm{~m}$ depth.

Genus Aricidea Webster, 1879

Subgenus Allia Strelzov, 1973

Remarks. Aricidea (Allia) mediterranea (Laubier and Ramos, 1974), is a Mediterranean species mainly characterized by having branchiae from chaetiger
5, (like Aricidea facilis Strelzov, 1973 and Aedicira oregonensis Fauchald and Hancock, 1981) and by a short Y-shaped median antenna, which, according to Laubier and Ramos (1974), may be replaced by a shorter, smaller simple one that was considered a regenerated form. However, after collecting several more specimens between 275 and $540 \mathrm{~m}$ depth in the Adriatic, Katzmann and Laubier (1975) stated “... il faut noter les ressemblances de cette espèce avec Aricidea (Allia) facilis Strelzov, 1973,... A. facilis ne possède cependant ni antenne bifurquée, ni lobes neuropodieux".

In the present samples (as well as in others from the continental slope off Galicia), we found several individuals that agree well with the second form of A. mediterranea (i.e., with simple, short and distally inflated, club-shaped antenna).

In turn, there is a unique species of Aricidea, A. (Allia) monicae, which is characterized by its peculiar interparapodial small digitiform lobes, regularly cylindrical and distally rounded, present in some anterior segments and its very short, cylindrical, distally rounded antenna (Laubier, 1967). A. monicae was again collected from the French Mediterranean continental shelf (Guille, 1970), and also from Mediterranean bathyal depths (Carpine, 1970), during the Polymède mission (Laubier and Ramos, 1974), in the Bay of Rosas (Desbruyères et $a l ., 1972)$ and in the Adriatic (Katzmann and Laubier, 1975). However, it has always been described as having a short, simple, cirriform median antenna (Gaston and McLelland, 1996).

In our samples, 12 specimens from Capbreton (as well as several more from the continental slope off Galicia) agree well with the description of $A$. monicae. However, one individual, non-distinguishable from A. monicae in most relevant characters, had a bifurcated median antenna very similar to that of Aricidea mediterranea and Aricidea (Aricidea) petacalcoensis León-González, Hernández-Guevara and Rodríguez-Valencia, 2006.

Therefore, Aricidea monicae, like Aricidea mediterranea, also seemed to have two forms, the predominant one being that with a simple antenna (as our finding is the first reported with bifurcated antenna found). This finding also suggests that the simple antenna may not be the result of a regeneration as stated by Laubier and Ramos (1974).

Due to the taxonomic importance of the antenna in the Paraonidae, we have considered each form as a different species: Aricidea (Allia) monicae Laubier, 1967 and Aricidea (Allia) sardai n. sp. (with simple 

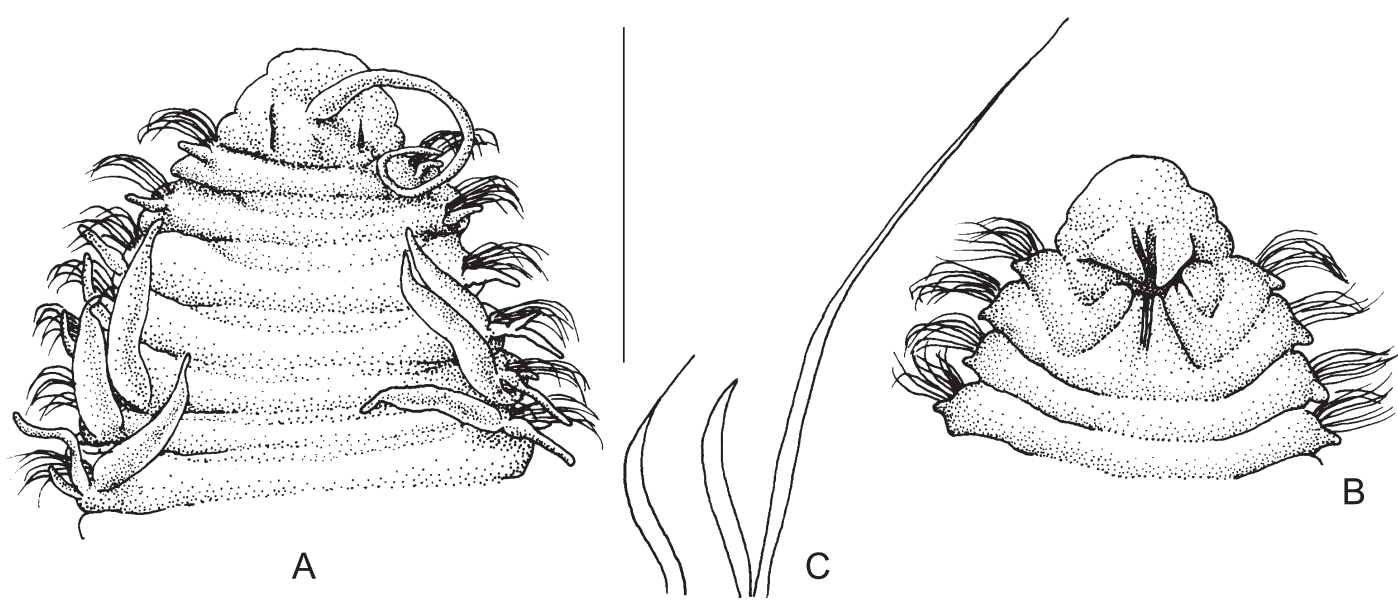

FIG. 14. - Aricidea (Allia) antennata: A, anterior region, dorsal view; B, anterior region, ventral view; C, modified ventral chaetae, chaetiger 39. Scale bar: A $820 \mu \mathrm{m}$; B $850 \mu \mathrm{m}$; C $60 \mu \mathrm{m}$.

antenna) and Aricidea (Allia) mediterranea (Laubier and Ramos, 1974) and Aricidea (Allia) bifurcata $\mathrm{n}$. sp. (with bifurcated antenna).

Aricidea (Allia) antennata Annenkova, 1934 (Figs 14 and 19A-B)

Aricidea antennata, Annenkova, 1934: 658, Figs. 1C, 2, 3B Aricidea (Allia) antennata, Blake, 1996: 48-50, Fig. 2.10 A-C. Aedicira antennata, Hartman, 1969: 51-52, Figs.1-4.

Aricidea uschakovi, Uschakov, 1955: 287, Fig. 103 D-I.- Imajima, 1973: 256-258, Fig. 1 A-K. Not Zachs, 1925.

Aricidea longicornuta, Berkeley and Berkeley, 1950: 53-55, Fig.2. Aricidea (Allia) quadrilobata, Strelzov, 1973: 88-91, Fig. 37 A-D (in part). Not Webster and Benedict, 1887.

Material examined. 13 specimens from Capbreton Canyon, Bay of Biscay, Atlantic Ocean (coordinates in Table 1). CB88/DI12 (4), CB88/DI13 (4), CB88/DI31 (1), CB88/DI33 (2), CB89/DI66 (1), CB89/KF41 (1).

Description. All specimens incomplete, up to 5.8 mm (mostly 2.12-5.56 mm) long, $1.01 \mathrm{~mm}$ (mostly 0.6-1.04 mm) wide for 39 (mostly 15-33) chaetigers. Body anteriorly enlarged, dorsoventrally flattened, dark brown.

Prostomium anteriorly rounded, trilobed, slightly wider than long, with median antenna long, slender, starting on mid-prostomium (Fig. 14A, 19A).

First two notopodial postchaetal lobes digitiform, becoming much longer, cirriform, from chaetiger 3 (Fig. 14A, 19A), to long, thin, filiform in posterior region; from first branchial segment, and in the following 7-8 chaetigers, notopodial postchaetal lobes biramous, with ventral branch much shorter (Fig. 19B). First 15-25 neuropodial postchaetal lobes well developed; prebranchial ones large, rounded, inflated (Fig. 14B), becoming progressively thinner, cirriform (Fig. 19B).

Branchiae starting at chaetiger 4, up to 15 pairs, cylindrical, with distal end filiform (1/w mostly between 4 and $5.5 ; 1=$ mostly between 0.25 and 0.38 $\mathrm{mm}$; max. $1=0.39 \mathrm{~mm}$ ) (Fig. 14A, 19A, B); posterior ones shorter.

Modified ventral chaetae of three types: simple, with filiform tip; and very long, curved aciculars with bristles on convex edge, with and without filiform tips (Fig. 14C).

Discussion. Aricidea quadrilobata Webster and Benedict, 1887 was first collected on the North American Atlantic coast. Since then, several similar species have been described: A. uschakowi Zachs, 1925, A. antennata, and A. longicornuta Berkeley and Berkeley, 1950 in the Pacific, and A. annae Laubier, 1967 in the Mediterranean. According to Strelzov (1973) all of them, except for A. uschakowi, should be considered as A. quadrilobata (including the most recent records of $A$. uschakowi). A. quadrilobata has biramous notopodial postchaetal lobes in the branchial region (Strelzov, 1973), a typical character of large individuals (width $>0.6 \mathrm{~mm}$ ). Conversely, Blake (1996) stated that A. antennata (from Pacific coasts) and A. quadrilobata (from Atlantic coasts) were different, the latter being characterized by a wide prostomium and simple notopodial postchaetal lobes, and the former by an anteriorly truncated prostomium, apparently trilobed, and biramous notopodial postchaetal lobes. All the specimens from Capbreton Canyon agree with $A$. antennata.

Distribution. Eastern Pacific, from Canada to southern California; Western Pacific, Japan, Sea of Okhotsk. Capbreton Canyon (Bay of Biscay). 492 to $1113 \mathrm{~m}$ depth. First record to the Atlantic. 

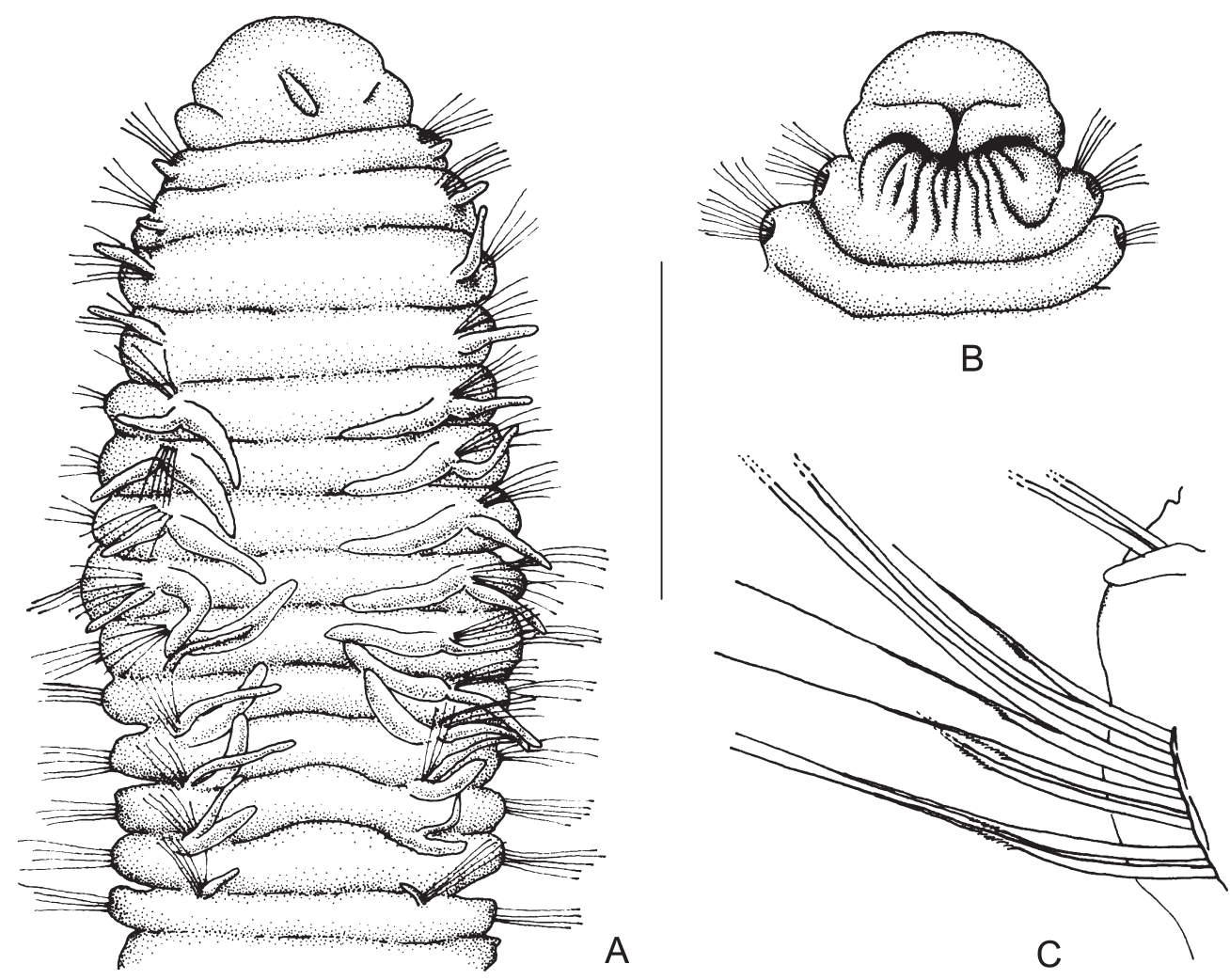

FIG. 15. - Aricidea (Allia) sardai n. sp. Holotype (MNCN 16.01/11206): A, anterior region, dorsal view; B, anterior region, ventral view; C, parapodium, chaetiger 67 . Scale bar: A $415 \mu \mathrm{m}$; B $410 \mu \mathrm{m}$; C $95 \mu \mathrm{m}$.

Aricidea (Allia) sardai n. sp. (Fig. 15)

? Aedicira mediterranea, Laubier and Ramos, 1974: 1134-1138 (in part).

Material examined. Two specimens from Capbreton Canyon, Bay of Biscay, Atlantic Ocean (coordinates in Table 1). CB89/KF50: Holotype (MNCN 16.01/11206) and one paratype (INSUB POL 333).

Description. All specimens incomplete. Holotype maximum width (in branchial region) $0.52 \mathrm{~mm}$, $7 \mathrm{~mm}$ long for 67 chaetigers; paratype $4.3 \mathrm{~mm}$ long, $0.44 \mathrm{~mm}$ wide for 57 chaetigers. Body dorsoventrally flattened.

Prostomium wide, anteriorly rounded. A pair of nuchal organs as slits. Median antenna short, clubshaped, on mid-prostomium, non-reaching its posterior margin (Fig. 15A). Posterior buccal lip with several longitudinal folds from anterior margin of chaetiger 1 (Fig. 15B).

Branchiae starting at chaetiger 5, 8-9 pairs, cirriform, rather short, distally blunt (1/w mostly between 4 and $5 ; 1=$ mostly between 0.08 and $0.15 \mathrm{~mm}$; max. $1=0.16 \mathrm{~mm})$ (Fig. 15A); last pair much shorter.

First two notopodial postchaetal lobes digitiform, becoming larger, cirriform from chaetiger 3 (Fig. 15A), considerably decreasing in size between penultimate branchial and first postbranchial segments, keeping that size in all other segments. Neuropodial postchaetal lobes tuberculated from chaetiger 1 to 15 .

Modified ventral chaetae from chaetiger 61 , as capillary chaetae attenuated and prolonged in a fine, long distal filament, with a pubescent area at attenuation level (Fig. 15C).

Etymology. This species is named in honour of Rafael Sardá, in recognition of his work on polychaetes of the Mediterranean Sea.

Discussion. With the new species herein described, the total number of taxa in the subgenus Aricidea (Allia) increases to 30, including a subspecies (Table 4). Aricidea (Allia) sardai n. sp. is closely related to Aricidea (Allia) facilis, Aricidea (Allia) mediterranea and Aedicira oregonensis, and all have branchiae starting from chaetiger 5. The new species differs from A. facilis in that it has neuropodial postchaetal lobes (from chaetiger 1 to 25), chaetiger 2 is not part of the posterior buccal lip, 

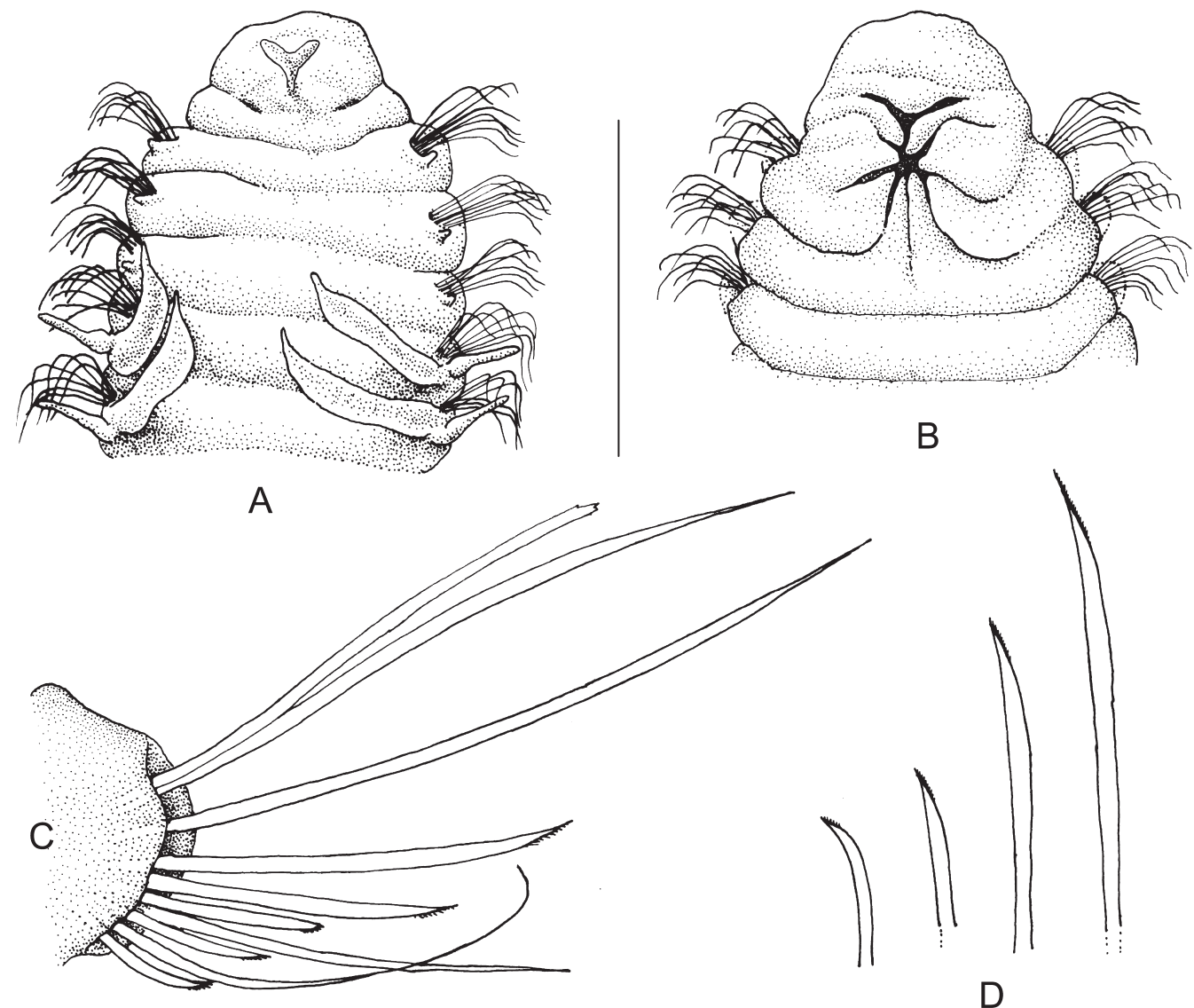

FIG. 16. - Aricidea (Allia) bifurcata n. sp. Holotype (MNCN 16.01/11207): A, anterior region, dorsal view; B, anterior region, ventral view; C, neuropodium, posterior chaetiger; D, modified ventral chaetae, posterior chaetiger. Scale bar: A $400 \mu \mathrm{m} ; \mathrm{B} 410 \mu \mathrm{m}$; C $80 \mu \mathrm{m}$; D $75 \mu \mathrm{m}$.

the modified ventral chaetae are non-acicular, it has more branchiae, and in the starting segment of the abrupt reduction in size of the notopodial postchaetal lobes (between the penultimate branchial and the first postbranchial segments). A. sardai $\mathrm{n}$. sp. is also easily distinguished from $A$. oregonensis because the latter has notopodial postchaetal lobes only from chaetiger 2 to about chaetiger 15-16.

The main difference between $A$. sardai n. sp. and A. mediterranea is the presence of a club-shaped median antenna, very similar to that of $A$. facilis, rather than a bifurcated one (see the Remarks section under Aricidea (Allia)). Moreover, in A. sardai n. sp., the first two notopodial postchaetal lobes are short and digitiform (only the first one is in A. mediterranea) and the reduction in size of the notopodial postchaetal lobes occurs between the penultimate branchial and the first postbranchial segments, and not between the first and second postbranchial segments, or even more posteriorly, as in A. mediterranea. Finally, the branchiae of $A$. sardai n. sp. are distally more blunt (not pointed, as in A. mediterranea).
Distribution. ? Mediterranean. Capbreton Canyon (Bay of Biscay). $1000 \mathrm{~m}$ depth.

Aricidea (Allia) bifurcata n. sp.

(Fig. 16)

Material examined. One specimen, Capbreton Canyon, Bay of Biscay, Atlantic Ocean (coordinates in Table 1). CB88/DI33- Holotype (MNCN 16.01/11207).

Description. Holotype incomplete specimen, maximum width (in branchial region) $0.49 \mathrm{~mm}$, $10.66 \mathrm{~mm}$ long for 41 chaetigers. Prebranchial and branchial regions wide, dorsoventrally flattened, becoming slender, filiform from mid-body to posterior end.

Prostomium clearly wider than long, distally rounded (Fig. 16A). Pair of nuchal organs as deep slits dividing the prostomium in two parts. Median antenna short, bifurcated, Y-shaped, located on midprostomium (Fig. 16A). Posterior buccal lip with folds starting at first two chaetigers (Fig. 16B).

Branchiae starting at chaetiger 4 , eight pairs, cylindrical, tapering to thin, long tips ( $1 / \mathrm{w}$ mostly 


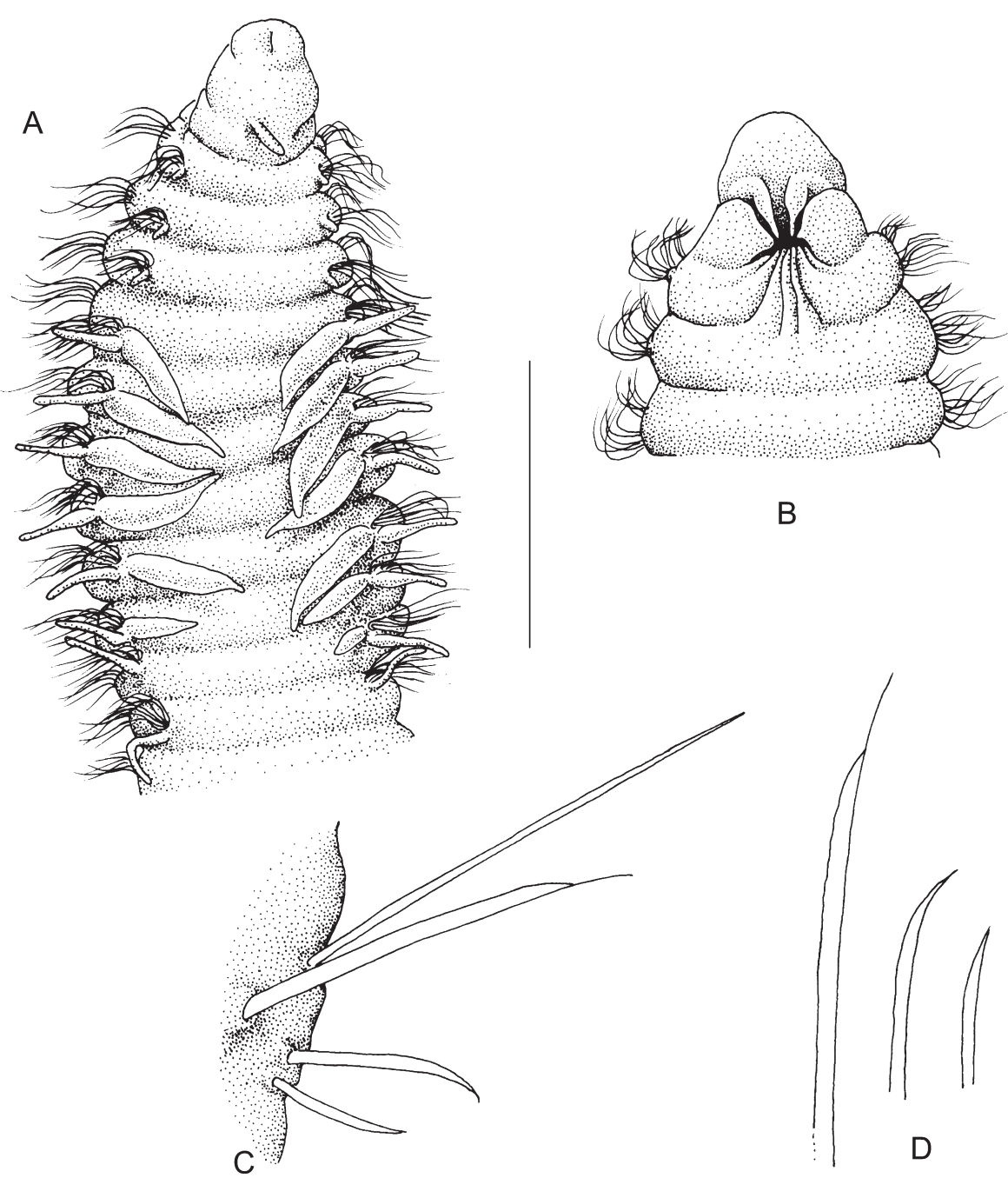

FIG. 17. - Aricidea (Allia) monicae: A, anterior region, dorsal view; B, anterior region, ventral view; C, neuropodium, chaetiger 44; D, modified ventral chaeta, chaetiger 44. Scale bar: A $470 \mu \mathrm{m}$; B $455 \mu \mathrm{m}$; C $90 \mu \mathrm{m}$; D $70 \mu \mathrm{m}$.

between 4.4 and $5.5 ; 1=$ mostly between 0.11 and $0.22 \mathrm{~mm}$; $\max .1=0.22 \mathrm{~mm}$ ); last two pairs distally blunt, rounded.

First three notopodial postchaetal lobes short, papilliform, becoming much longer, cirriform from chaetiger 4 (Fig. 16A); thin, filiform in postbranchial segments. Neuropodial postchaetal lobes absent.

Modified ventral chaetae from chaetiger 29, acicular, with distal end finely pilose (Fig. 16C, D).

Interparapodial cirriform lobes present, numbering 1 to 4 , between chaetigers 8 and 17, and 3 to 4 between chaetigers 10 and 14 .

Etymology. The species name refers to the shape of median antenna.

Discussion. Aricidea bifurcata $\mathrm{n}$. sp. is compared with other taxa of the subgenus Aricidea (Allia) in
Table 4. The main morphological characters, interparapodial lobes included, resemble those of Aricidea (Allia) monicae, but can be distinguished by its bifurcated median antenna, very similar to the antennae of Aricidea (Allia) mediterranea and Aricidea (Aricidea) petacalcoensis (see the Remark section under Aricidea (Allia)).

Distribution. Capbreton Canyon, Bay of Biscay, 492 to $495 \mathrm{~m}$ depth.

\section{Aricidea (Allia) monicae Laubier, 1967}

(Fig. 17)

Aricidea monicae, Laubier, 1967: 118-124, Fig. 6 A-E, 7 A-H.Laubier and Ramos, 1974: 1117.- Katzmann and Laubier, 1975: 578.- Campoy, 1981: 20.

Aricidea (Allia) monicae, Strelzov, 1973: 72-74, Fig. 28 A-E.- Blake, 1996: 52-54, Fig. 2.12 A-F.- Gil and Sardá, 1999: 299-300. 
Material examined. Thirteen specimens from Capbreton Canyon, Bay of Biscay, Atlantic Ocean (coordinates in Table 1). CB88/DI12 (5), CB88/DI13 (1), CB88/DI26 (1), CB88/DI31 (1), CB88/DI33 (4), CB89/DI66 (1).

Description. One complete specimen, $4.52 \mathrm{~mm}$ long, $0.49 \mathrm{~mm}$ wide (in branchial region), ranging from 0.46 to $0.58 \mathrm{~mm}$ wide. Median antenna short, cirriform on mid-prostomium. Branchiae starting from chaetiger 4, 6-8 pairs, cylindrical, distally pointed (1/w mostly between 4 and $5 ; 1=$ mostly between 0.14 and $0.20 \mathrm{~mm}$; max. $1=0.23$ $\mathrm{mm}$ ) (Fig. 17A). First three notopodial postchaetal lobes short; much longer, cirriform from chaetiger 4; thin, filiform in postbranchial segments (Fig. 17A).
Interparapodial cirriform lobes in some anterior segments. Ventral modified chaetae from chaetiger 27 to 29 (Fig. 17C).

Distribution. Bathyal (100 to $3000 \mathrm{~m}$ depth) in Atlantic (Portugal) and Adriatic Sea; 590 to $1745 \mathrm{~m}$ depth in California; 492 to $1113 \mathrm{~m}$ depth in Capbreton Canyon, Bay of Biscay.

\section{Aricidea (Allia) mirunekoa n. sp.} (Figs. 18 and 19 C,D)

Material examined. 16 specimens from Capbreton Canyon, Bay of Biscay, Atlantic Ocean (coordinates in Table 1). CB88/DI19 (1), CB88/DI21 (4), CB88/DI31: Holotype (MNCN 16.01/11208) and
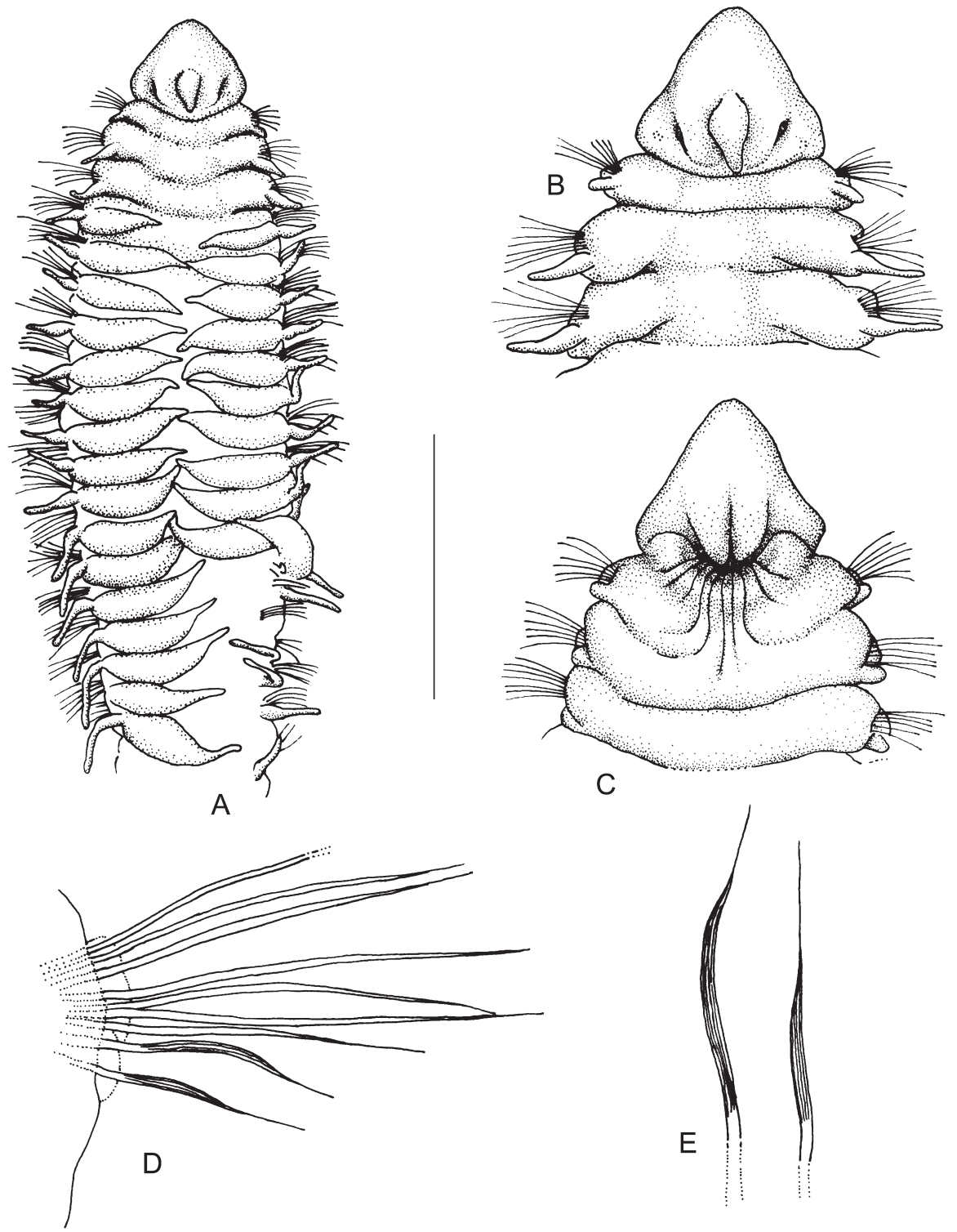

FIG. 18. - Aricidea (Allia) mirunekoa n. sp.: A-B, anterior region, dorsal view; C, anterior region, ventral view; Holotype (MNCN 16.01/11209) D, neuropodium, chaetiger 27; Holotype (MNCN 16.01/11209) E, modified ventral chaeta, chaetiger 27. Scale bar: A $415 \mu \mathrm{m}$; B $425 \mu \mathrm{m}$; C 425 um; D 80 um; E 55 um. 


\begin{tabular}{|c|c|c|c|c|c|c|c|c|c|c|c|}
\hline 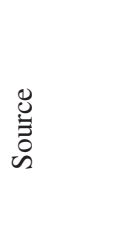 & 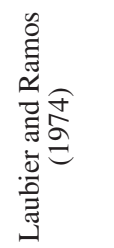 & 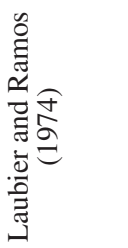 & 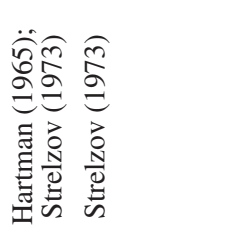 & 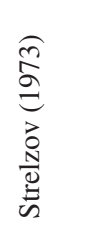 & 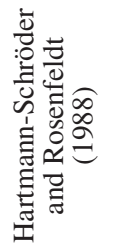 & 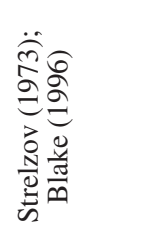 & 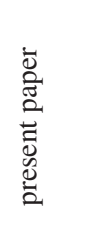 & 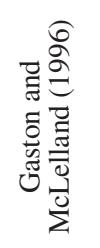 & 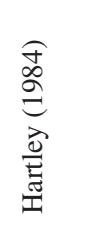 & 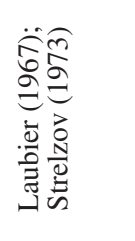 & 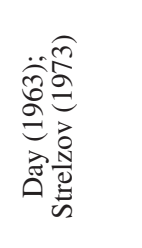 \\
\hline 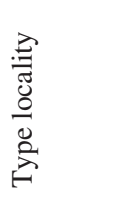 & 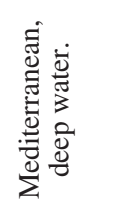 & 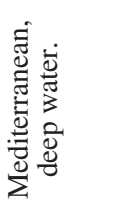 & 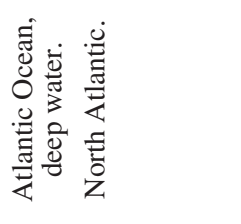 & 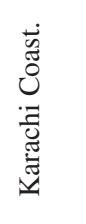 & 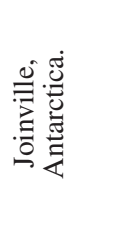 & 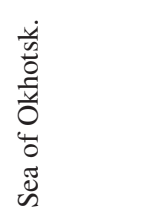 & 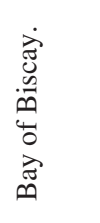 & 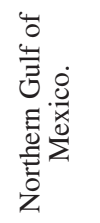 & 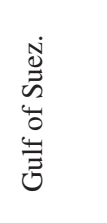 & 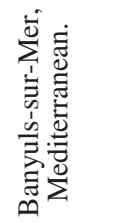 & 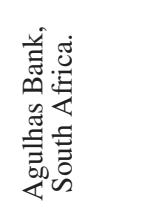 \\
\hline 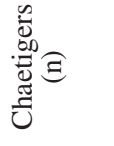 & 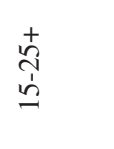 & 8 & $\begin{array}{l}+ \\
\stackrel{5}{n}\end{array}$ & $\underset{త}{+}$ & $\frac{t}{\infty}$ & ్ㅗ & $\stackrel{+}{\forall}$ & a. & $\stackrel{+}{F}$ & $\stackrel{+}{\stackrel{t}{\sigma}}$ & $\begin{array}{l}+ \\
\infty \\
\infty\end{array}$ \\
\hline 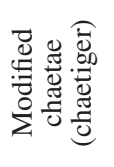 & $\stackrel{m}{i}$ & 守 & 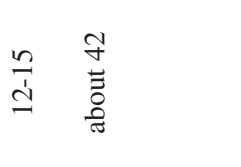 & $a$ & $\stackrel{\vec{c}}{a}$ & î̀ & $\stackrel{\lambda}{ }$ & 8 & $m$ & 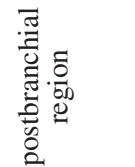 & in \\
\hline 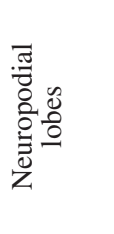 & 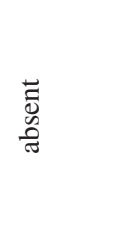 & $\begin{array}{l}\vec{z} \\
\text { एँ } \\
\text { ले }\end{array}$ & 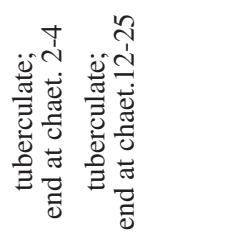 & $\begin{array}{l}\overrightarrow{\overline{0}} \\
\text { o. } \\
\vec{\sigma}\end{array}$ & 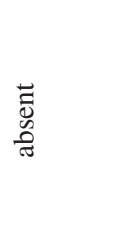 & 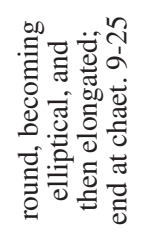 & $\begin{array}{l}\vec{\Xi} \\
\text { ते } \\
\text { ते }\end{array}$ & 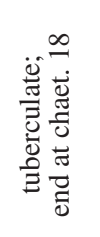 & 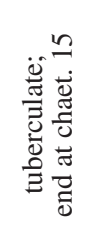 & 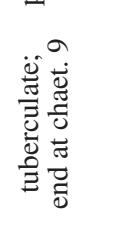 & 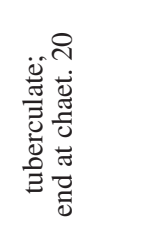 \\
\hline 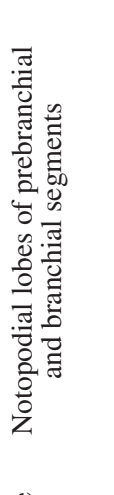 & 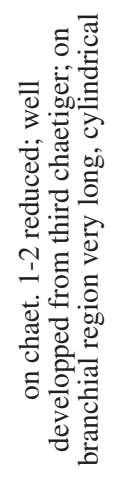 & 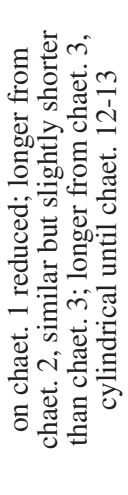 & 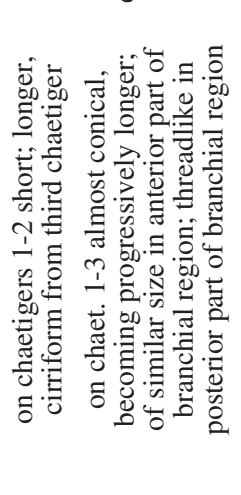 & 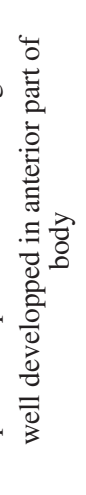 & 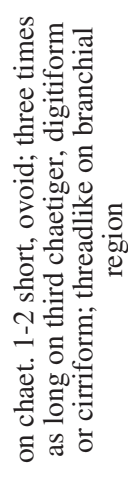 & 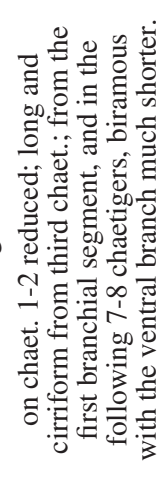 & 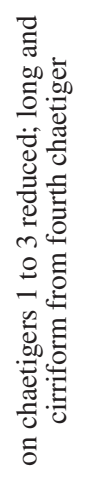 & 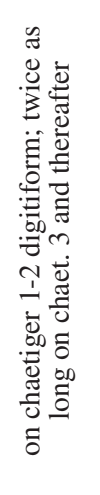 & 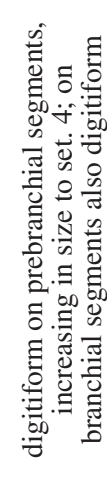 & 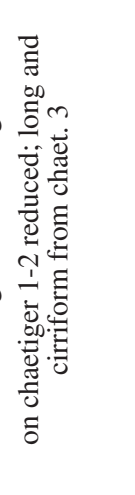 & 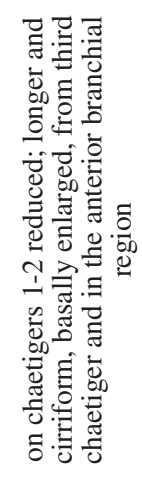 \\
\hline 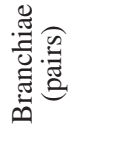 & $\frac{n}{\mathfrak{I}}$ & 0 & $\begin{array}{ll}0 & 0 \\
0 & 0 \\
0 & 0 \\
0 & 0 \\
\vdots\end{array}$ & $\begin{array}{l}\stackrel{q}{q} \\
\stackrel{9}{9} \\
\stackrel{9}{9}\end{array}$ & $\infty$ & 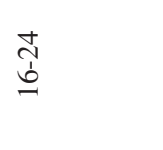 & $\infty$ & ले & $\vec{\sim}$ & $\begin{array}{l}0 \\
\frac{0}{9} \\
3\end{array}$ & $\begin{array}{l}\stackrel{q}{+} \\
\stackrel{\Xi}{0} \\
\frac{\sigma}{\sigma}\end{array}$ \\
\hline 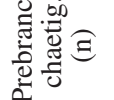 & $m$ & 0 & $0 m$ & $m$ & $m$ & $n$ & $m$ & $m$ & $n$ & $n$ & $m$ \\
\hline 营 & 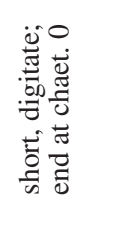 & 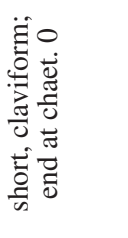 & 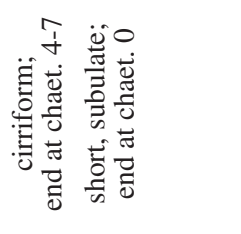 & 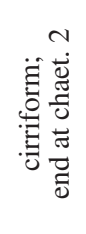 & 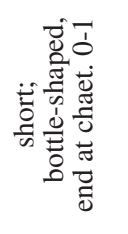 & 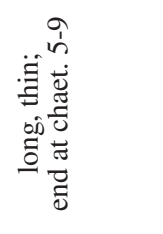 & 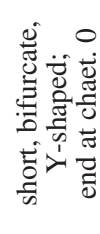 & 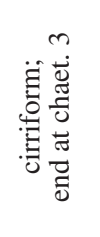 & 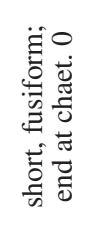 & 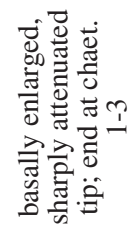 & 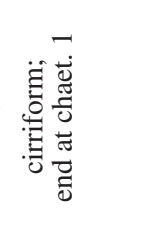 \\
\hline & 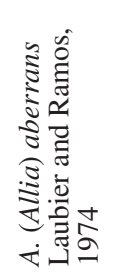 & 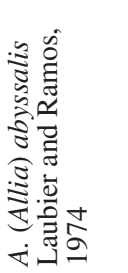 & 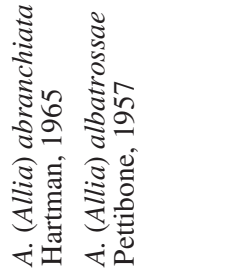 & 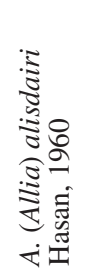 & 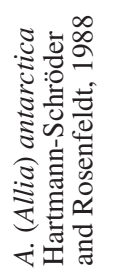 & 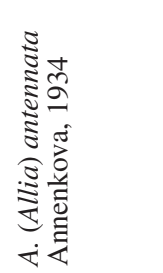 & 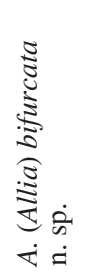 & 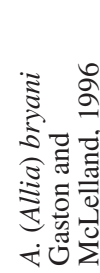 & 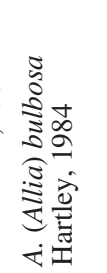 & 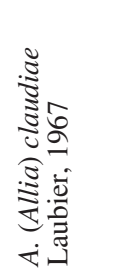 & 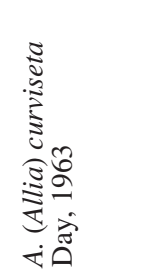 \\
\hline
\end{tabular}




\begin{tabular}{|c|c|c|c|c|c|c|c|c|c|c|c|c|c|}
\hline 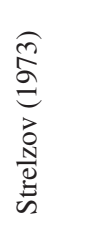 & 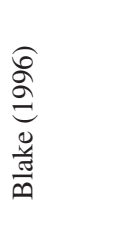 & 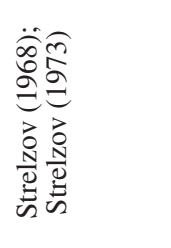 & 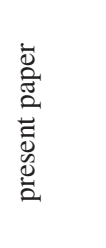 & 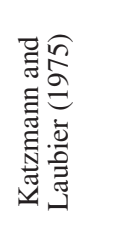 & 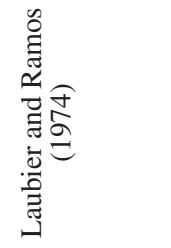 & 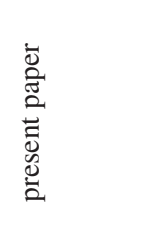 & 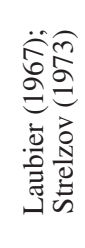 & 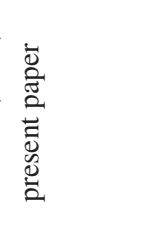 & 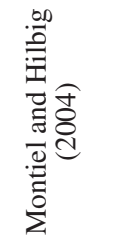 & 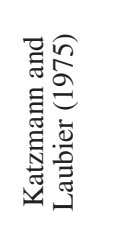 & 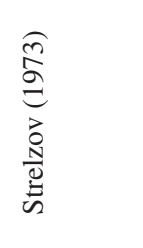 & 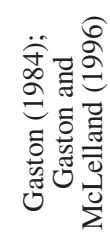 & 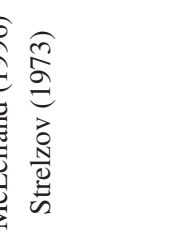 \\
\hline 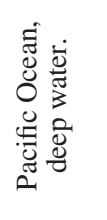 & 串 & 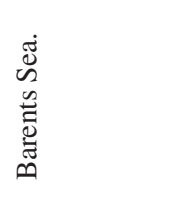 & 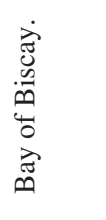 & 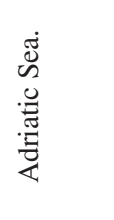 & 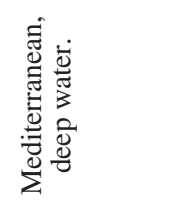 & 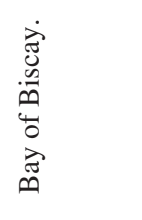 & 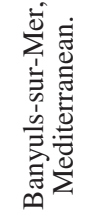 & 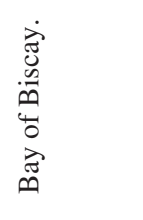 & 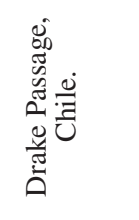 & 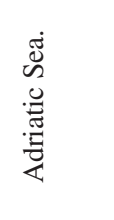 & 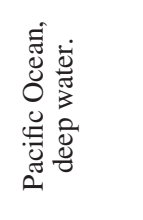 & 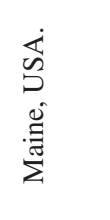 & 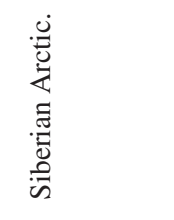 \\
\hline$\stackrel{+}{\stackrel{+}{n}}$ & $\stackrel{+}{+}$ & a. & $\stackrel{+}{\sim}$ & $\stackrel{+}{0}$ & a. & 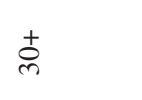 & $\begin{array}{l}\infty \\
\dot{0} \\
+ \\
+\end{array}$ & $\frac{ \pm}{n}$ & $\infty$ & $\stackrel{+}{\mathcal{f}}$ & $\stackrel{+}{\circ}$ & $\sigma$ & $\stackrel{+}{+}$ \\
\hline $\begin{array}{l}\text { fे } \\
\text { dे }\end{array}$ & rq & 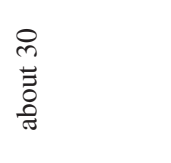 & $\begin{array}{l}\text { के } \\
\ddot{n}\end{array}$ & $m$ & q & $\ddot{\sim}$ & $\begin{array}{l}\overrightarrow{\hat{\lambda}} \\
\stackrel{\hat{\lambda}}{ }\end{array}$ & $\begin{array}{l}\stackrel{n}{m} \\
m \\
m\end{array}$ & 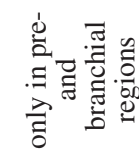 & त्र & $\begin{array}{l}\stackrel{\infty}{\sim} \\
\stackrel{\sim}{\sim}\end{array}$ & $\begin{array}{l}\stackrel{\infty}{N} \\
\stackrel{ஸ}{-}\end{array}$ & $\begin{array}{l}\text { ñ } \\
\stackrel{\Xi}{0} \\
\stackrel{\sigma}{\sigma}\end{array}$ \\
\hline $\begin{array}{l}\overrightarrow{\bar{v}} \\
\text { o } \\
\vec{\sigma}\end{array}$ & 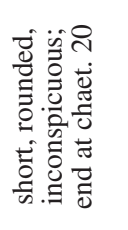 & 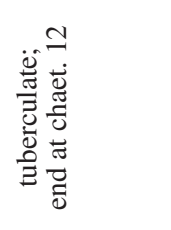 & 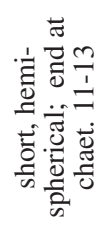 & 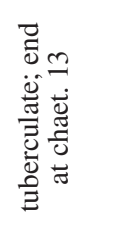 & 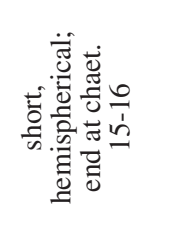 & 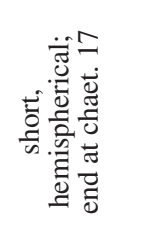 & 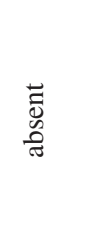 & 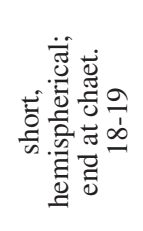 & $\begin{array}{l}\mid \overrightarrow{0} \\
\overrightarrow{0} \\
\vec{\sigma}\end{array}$ & 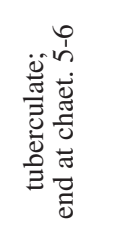 & $\begin{array}{l}\overrightarrow{\bar{v}} \\
\text { o } \\
\text { त्र }\end{array}$ & 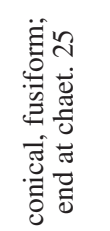 & 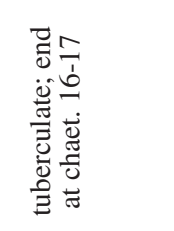 \\
\hline 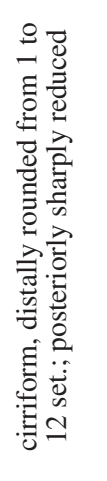 & 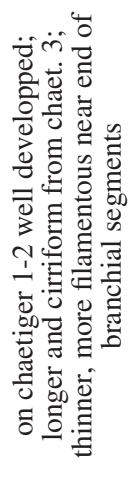 & 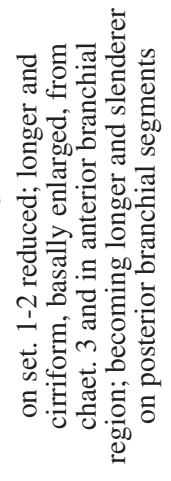 & 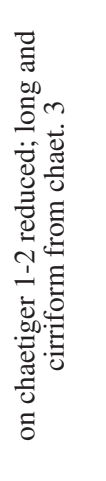 & 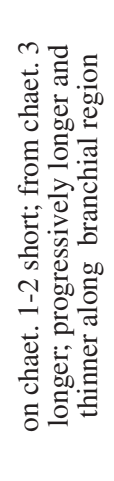 & 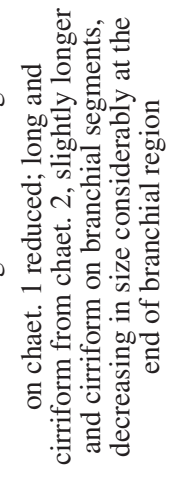 & 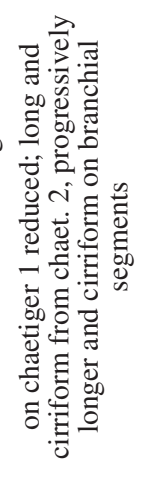 & 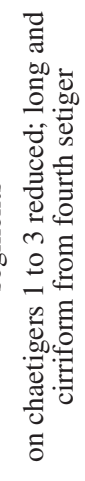 & 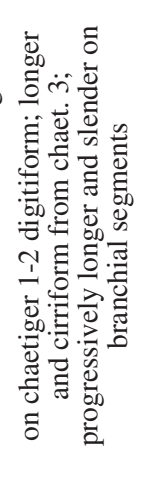 & 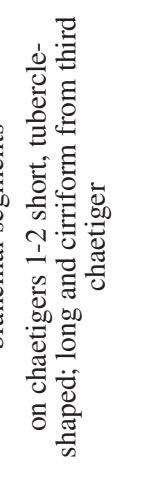 & 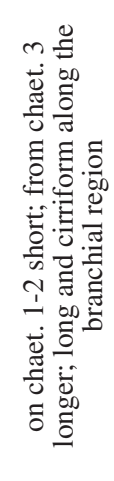 & 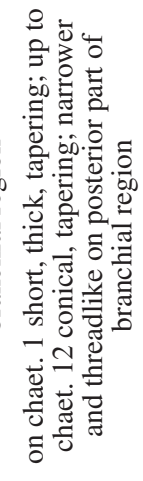 & 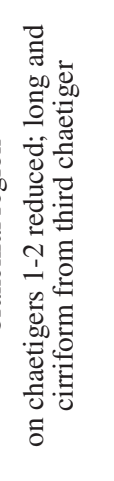 & 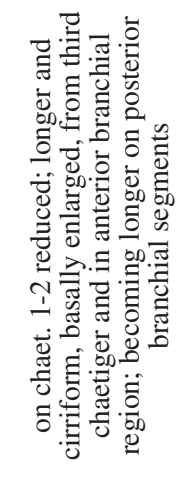 \\
\hline$\frac{n}{1}$ & $\begin{array}{l}\text { ते } \\
\text { ปे }\end{array}$ & $\frac{a}{\grave{n}}$ & $\frac{1}{a}$ & 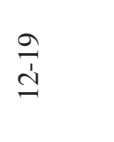 & $\dot{a}$ & $\begin{array}{l}\text { İ } \\
0 \\
\vdots \\
\Xi\end{array}$ & $\stackrel{a}{\dot{t}}$ & $\begin{array}{l}\overrightarrow{1} \\
\stackrel{2}{\Omega}\end{array}$ & $\begin{array}{l}\stackrel{+}{\sim} \\
\stackrel{\omega}{n}\end{array}$ & $\frac{m}{b}$ & $\frac{\infty}{\stackrel{I}{I}}$ & $\begin{array}{l}\text { సे } \\
\stackrel{0}{0} \\
ٍ\end{array}$ & $\frac{\infty}{\dot{m}}$ \\
\hline ¿े & $m$ & $m$ & $m$ & $m$ & 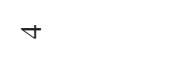 & $m$ & $n$ & $m$ & $m$ & $m$ & $m$ & $m$ & $m$ \\
\hline 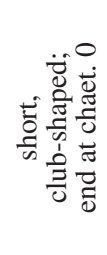 & 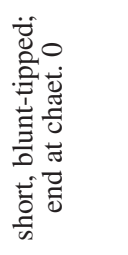 & 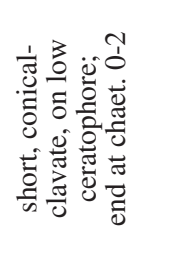 & 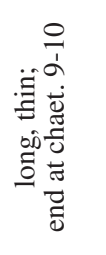 & 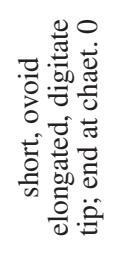 & 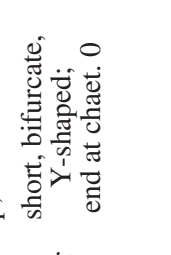 & 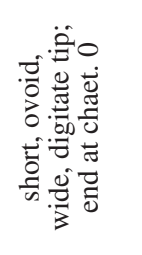 & 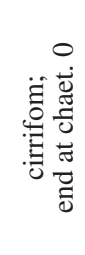 & 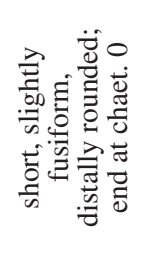 & 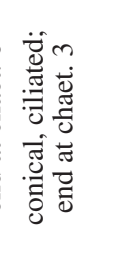 & 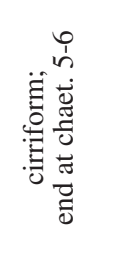 & 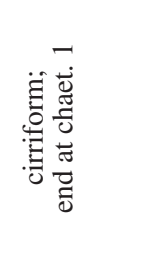 & 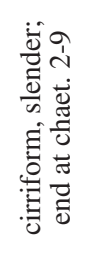 & 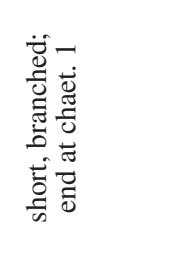 \\
\hline 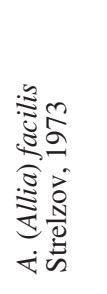 & 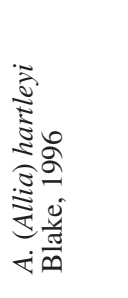 & 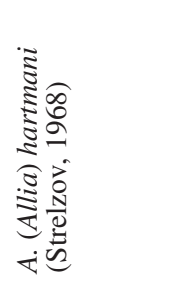 & 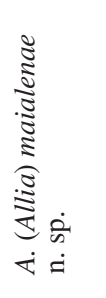 & 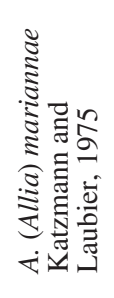 & 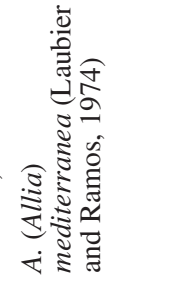 & 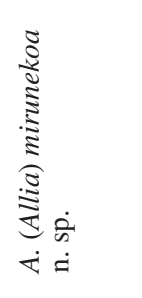 & 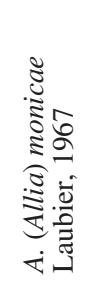 & 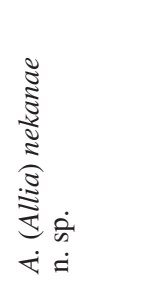 & 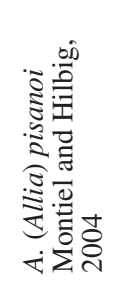 & 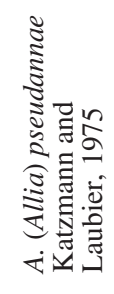 & 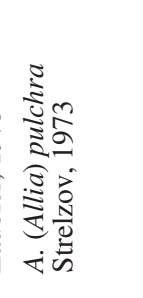 & 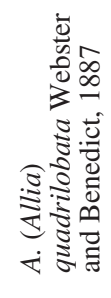 & 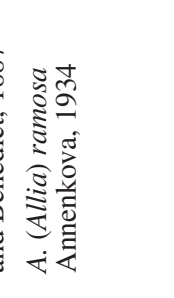 \\
\hline
\end{tabular}


4 specimens, CB88/DI37: one paratype (MNCN 16.01/11209), two paratypes (INSUB POL 334) and 3 specimens.

Description. All specimens incomplete, largest one $10.9 \mathrm{~mm}$ long, $0.84 \mathrm{~mm}$ wide for $25-30$ chaetigers. Holotype fragmented, $1.8 \mathrm{~mm}$ long, $0.48 \mathrm{~mm}$ wide (in branchial region) for 20 chaetigers and 1.07 $\mathrm{mm}$ long for 7 chaetigers. Body wide, dorsoventrally flattened anteriorly, more slender at final part of branchial region.

Prostomium conical, distally rounded, slightly wider than long (Fig. 18A, B, 19C). Nuchal organs as a pair of oblique, deep slits. Two dark eyes, laterally at base of prostomium. Median antenna short, seldom reaching posterior margin of prostomium, wide, ovoid, distally digitiform (Fig. 18A,B, 19C). Posterior buccal lip with several longitudinal folds starting from chaetiger 1 and anterior part of chaetiger 2 (Fig. 18C, 19D).

Branchiae starting from chaetiger 4, up to 22 pairs, wide, foliaceous, distally pointed (1/w mostly between 2.6 and $3.5 ; 1=$ mostly between 0.2 and 0.35 $\mathrm{mm}$; max. $1=0.38 \mathrm{~mm}$ ) (Fig. 18A, 19C); anterior ones slightly exceeding median body line; becoming progressively larger, with long, filiform tips; to as wide as body width when posterior-most.

First notopodial postchaetal lobe short, ovoid; becoming more than two times longer, cirriform from chaetiger 2 (Fig. 18B), progressively longer in branchial region to long, thin, filiform in posterior region (Fig. 18A, 19C). Neuropodial postchaetal lobes hemispherical in chaetigers 1-17 in large specimens (Fig. 18C).

Ventral modified chaetae from chaetiger 23 (only observed in one specimen), as modified capillary chaetae, short, with narrow region, slightly sigmoid, smooth, continuing in a straight, very fine terminal extension (Fig. 18D, E).

Etymology. This species is fondly dedicated to all members of the family Miru.

Discussion. Aricidea mirunekoa n. sp. closely resembles Aricidea (Allia) bulbosa, Aricidea (Allia) hartmani (Strelzov, 1968), Aricidea (Allia) mariannae and Aricidea (Allia) hartleyi Blake, 1996 (Table 4). The new species is distinguished from A. bulbosa mainly by its median antenna, which is wider, ovoid, and not fusiform, and by its posterior buccal lip, which is formed by the first two chaetigers rather than by the first alone. Aricidea mirunekoa n. sp. differs from $A$. hartleyi by its median antenna, which is 

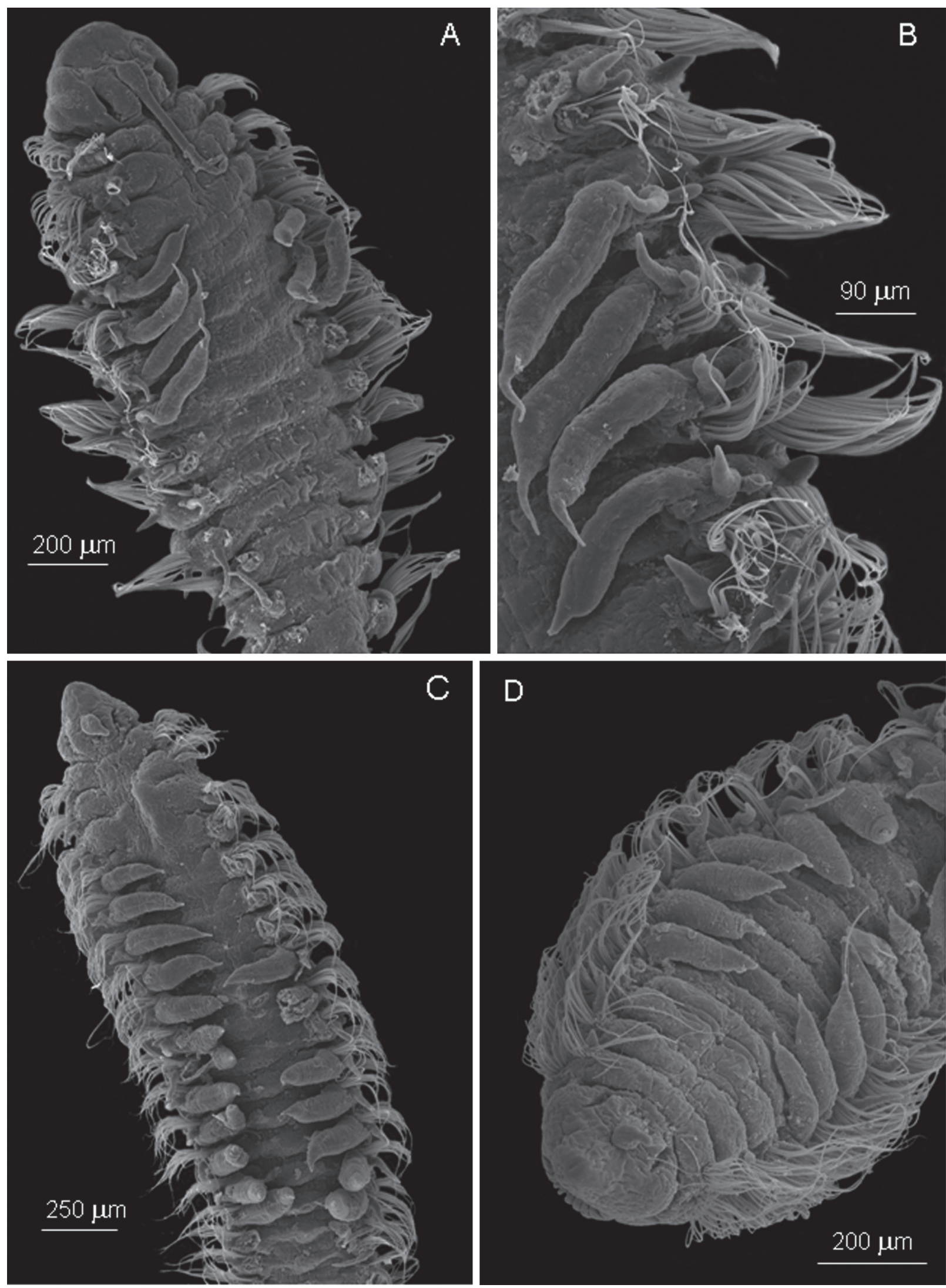

FIG. 19. - Aricidea (Allia) antennata: A, anterior region, dorsal view; B, branchial region, chaetigers 5-8, left side of animal. Aricidea (Allia) mirunekoa n. sp.: C-D, anterior region, dorsal view. Scale bar: A $200 \mu \mathrm{m}$; B $90 \mu \mathrm{m}$; C $250 \mu \mathrm{m}$; D $200 \mu \mathrm{m}$. 

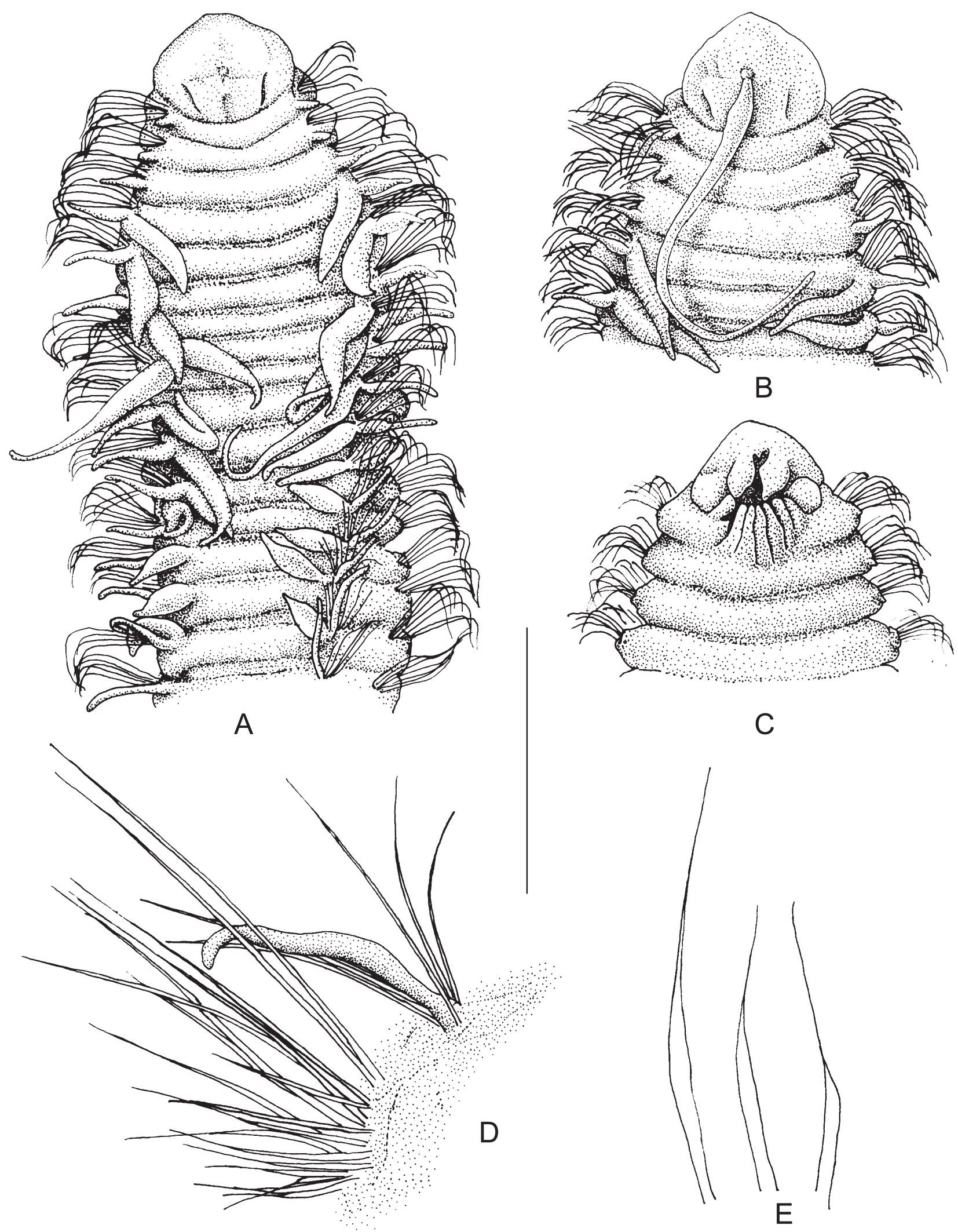

FIg. 20. - Aricidea (Allia) maialenae n. sp.: A, anterior region, dorsal view; B, anterior region, dorsal view; Holotype (MNCN 16.01/11211); $\mathrm{C}$, anterior region, ventral view; D, parapodium, chaetiger 33; E, modified ventral chaeta, chaetiger 33. Scale bar: A $480 \mu \mathrm{m}$; B $490 \mu \mathrm{m}$; C $475 \mu \mathrm{m} ; \mathrm{D} 70 \mu \mathrm{m} ; \mathrm{E} 120 \mu \mathrm{m}$. 
enlarged in the median region (uniform in diameter in A. hartleyi), and by its branchiae, which are wider and with a long and filiform distal end. The main difference from A. mariannae and A. hartmani is in its notopodial postchaetal lobes, as only that of the first chaetiger is short (the first two in the two other species). In addition, it differs from A. hartmani by having larger branchiae, with elongated distal points, and an ovoid, shorter median antenna. All specimens of the new species have a median antenna similar to A. mariannae but much wider, which is also the case of the branchiae.

Distribution. Capbreton Canyon, Bay of Biscay, 480 to $968 \mathrm{~m}$ depth.

\section{Aricidea (Allia) maialenae $\mathrm{n}$. sp.}

(Figs. 20 and 23A,B)

Material examined. 13 specimens from Capbreton Canyon, Bay of Biscay, Atlantic Ocean (coordinates in Table 1). CB88/DI12 (3), CB88/DI13: Holotype (MNCN 16.01/11210), one paratype (MNCN 16.01/11211) and 3 specimens, CB88/DI19 (1), CB88/DI26 (2), CB89/DI66: two paratypes (INSUB POL 335).

Description. All specimens incomplete, largest one $4.25 \mathrm{~mm}$ long, $0.56 \mathrm{~mm}$ wide for 32 chaetigers, ranging from 1.49 to $4.06 \mathrm{~mm}$ long, 0.41 to $0.61 \mathrm{~mm}$ wide for 17-31 chaetigers. Holotype $3.87 \mathrm{~mm}$ long, $0.52 \mathrm{~mm}$ wide (in branchial region) for 31 chaetigers. Body dorsoventrally flattened, with enlarged anterior region.

Prostomium rounded, slightly wider than long (Fig. 20A,B, 23A, B). Median antenna inserted on mid-prostomium, very long, directed backwards, reaching chaetiger 9-10 (Fig. 20B, 23A, B); easily lost (9 of 13 specimens with visible scar of lost antenna) (Fig. 20A). Posterior buccal lip with 6-8 longitudinal folds starting from chaetiger 1 and anterior part of chaetiger 2 (Fig. 20C).

Branchiae starting from chaetiger 4, 9-12 pairs, cylindrical, with distal thin tips (1/w mostly between 2.5 and $4.5 ; 1=$ mostly between 0.08 and $0.23 \mathrm{~mm}$; $\max .1=0.23 \mathrm{~mm}$ ) (Fig. 20A, 23A, B), reaching maximum length (equal to interbranchial width) in branchial segments 5-6, with long, slender, filiform distal ends; shorter when posterior-most.

First two notopodial postchaetal lobes short; longer, cirriform from chaetiger 3; longer, slender in postbranchial region (Fig. 20A, B, D). Neuropodial postchaetal lobes reduced to hemispherical papilla, from chaetiger 1 to $11-13$ (Fig. 20C).
Modified ventral chaetae from chaetiger 25-30, as modified capillary chaetae with a narrow sigmoid region, smooth, continuing in a straight terminal extension (Fig. 20E); 4-5 on each posterior segment, shorter, more sigmoid when more ventral (Fig. 20D).

Etymology. This species is fondly dedicated to Maialen Agirrezabalaga Arraras.

Discussion. Aricidea (Allia) maialenae n. sp. resembles Aricidea (Allia) quadrilobata, Aricidea (Allia) antennata and Aricidea (Allia) pseudannae (Table 4). It is distinguished from the first two species mainly in having hemispherical neuropodial postchaetal lobes and modified ventral chaetae of one kind (cirriform lobes and three kinds of modified ventral chaetae in A. quadrilobata and A. antennata) and from the last species in having a longer, backward directed median antenna, branchiae on the central branchial region longer and with longer and filiform distal end, and the folds forming the posterior buccal lip originating from chaetiger 1 and 2 (only from chaetiger 1 in A. pseudannae).

Distribution. Capbreton Canyon, Bay of Biscay, between 492 to $1113 \mathrm{~m}$ depth.

Aricidea (Allia) claudiae Laubier, 1967 (Fig. $21 \mathrm{~A}$ )

Aricidea claudiae Laubier, 1967: 124-128, Fig. 9 A-E.- Laubier and Ramos, 1974: 1113.- Campoy, 1981: 19, Fig. 3 A-C. Aricidea (Allia) claudiae, Strelzov, 1973: 77-79, Fig. 31 A-G.Katzmann and Laubier, 1975: 575.

Material examined. One specimen from Capbreton Canyon, Bay of Biscay, Atlantic Ocean (coordinates in Table 1): CB88/DI37.

Description. Specimen incomplete, $5.15 \mathrm{~mm}$ long, $0.44 \mathrm{~mm}$ wide (in branchial region) for 45 chaetigers. Prostomium triangular, with nuchal organs as a pair of deep slits. Median antenna as long as prostomium, directed backwards, reaching chaetiger 2 (Fig. 21A). Antenna cylindrical with distal end narrower (half width than in basal region). First two notopodial postchaetal lobes short, digitiform; longer, cirriform from chaetiger 3. Branchiae starting from chaetiger 4, 15 pairs, wide at base, with a distal cirriform filament. First branchial segment (chaetiger 4) with one big mid-dorsal rounded papilla (Fig. 21A). Modified ventral chaetae as capillary with distal end attenuated. 


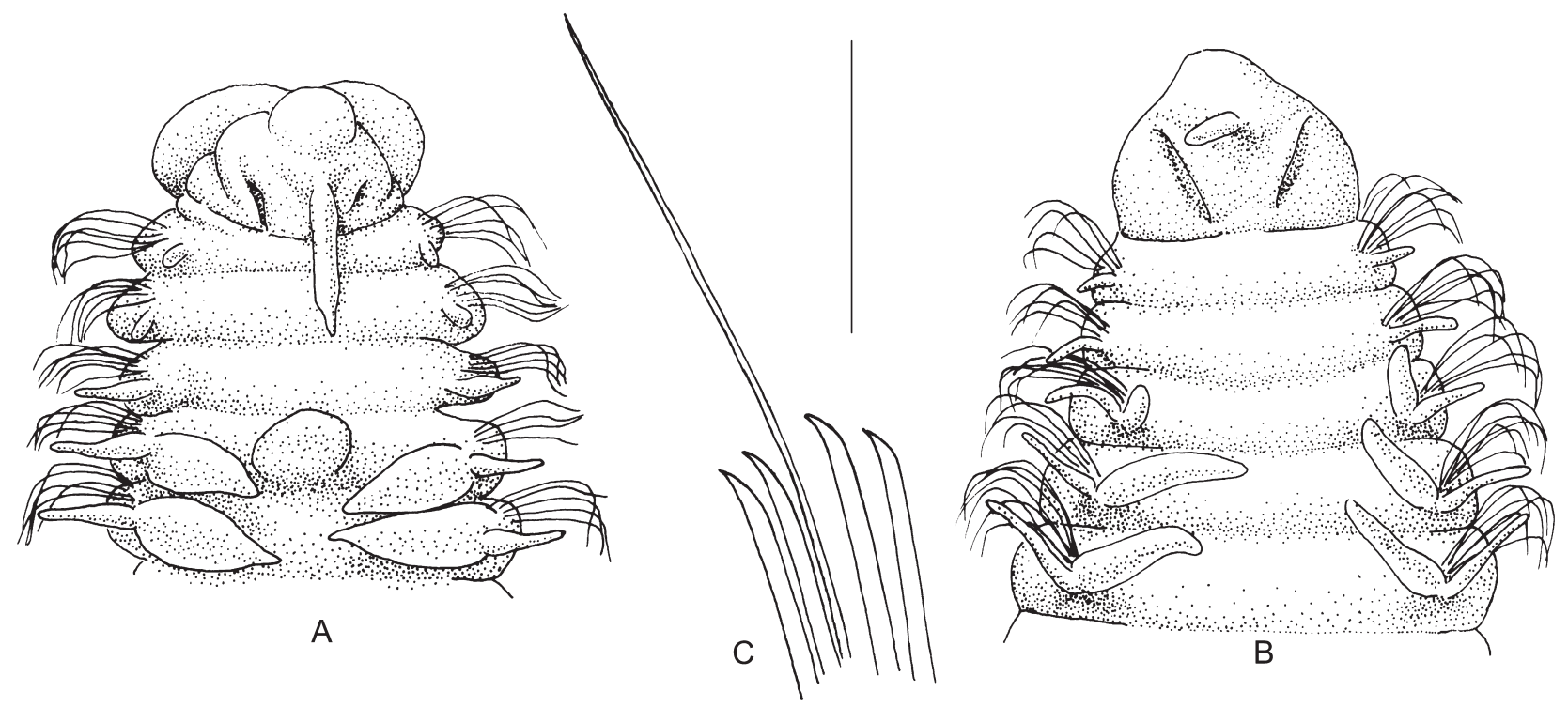

FIG. 21. - Aricidea (Allia) claudiae: A, anterior region, dorsal view. Aricidea (Acmira) simonae: B, anterior region, dorsal view; C, modified ventral chaetae, chaetiger 43. Scale bar: A $295 \mu \mathrm{m}$; B $355 \mu \mathrm{m}$; C $65 \mu \mathrm{m}$.

Distribution. Mediterranean, Adriatic, Black Sea, NE Atlantic (Basque Coast): 20 to $150 \mathrm{~m}$ depth. Capbreton Canyon (Bay of Biscay): 508 to $576 \mathrm{~m}$ depth. The present record extends its bathymetric distribution from the continental shelf (as in Katzmann and Laubier, 1975) to the continental slope.

Aricidea (Allia) nekanae n. sp. (Figs. 22 and 23 C,D)

Material examined. 6 specimens from Capbreton Canyon, Bay of Biscay, Atlantic Ocean (coordinates in Table 1). CB88/DI33: Holotype (MNCN 16.01/11212), one paratype (MNCN 16.01/11213), one paratype (INSUB POL 336) and 3 specimens.

Description. All specimens incomplete, largest one $9.6 \mathrm{~mm}$ long for 51 chaetigers, smallest one 3.01 $\mathrm{mm}$ long for 15 chaetigers. Holotype $8.95 \mathrm{~mm}$ long, $0.55 \mathrm{~mm}$ wide (in branchial region) for 49 chaetigers. Anterior region wide, dorsoventrally flattened. Posterior region slender, cylindrical. Prostomium subtriangular, as wider as long, rounded at base, more conical distally (Fig. 22A, 23C, D). One pair of nuchal organs as deep slits. One pair of lateral eyes at base of prostomium. Median antenna short, slightly fusiform, distally rounded, on mid-anterior prostomium (Fig. 22A, 23D). Posterior buccal lip with several longitudinal folds starting from first two chaetigers (Fig. 22B).

First two notopodial postchaetal lobes well developed, digitiform (Fig. 22A, 23D); at least two times longer, cirriform from chaetiger 3 ; becoming progressively longer, slender in branchial region to long, filiform in postbranchial region. Neuropodial postchaetal lobes as hemispheric tubercles in chaetigers 1 to 18/19 (Fig. 22B).

Branchiae starting from chaetiger 4, 19-21 pairs (1/w mostly between 2.2 and $2.8 ; 1=$ mostly between 0.15 and $0.23 \mathrm{~mm}$; max. $1=0.23 \mathrm{~mm}$ ); first 7-9 pairs short, thick, distally rounded; next ones with tips distally thin, filiform; becoming more bulbous posteriorly. Inner part of branchiae with pigmented granules in two parallel rows (Fig. 22A, 23A).

Anterior dorsal and ventral chaetae limbate, capillary, sigmoid; 1-2 dorsal-most very fine, capillary in posterior segments, absent in most chaetigers.

Modified ventral chaetae from chaetiger 33-35, as modified capillary abruptly narrowing in distal part, tapering to a fine filament (Fig. 22C, D).

Pygidium unknown.

Etymology. This species is fondly dedicated to Nekane Arraras Garaikoetxea.

Discussion. A. nekanae n. sp. is compared with other taxa of the subgenus in Table 4. This new species differs from Aricidea (Allia) bulbosa, mainly in having a shorter antenna, located on the mid-anterior part of the prostomium, as well as in having a posterior buccal lip formed by the buccal segment and the first two chaetigers and by having the first branchial pairs distally rounded (as in Aedicira belgicae sensu Imajima, 1973) and not pointed. 


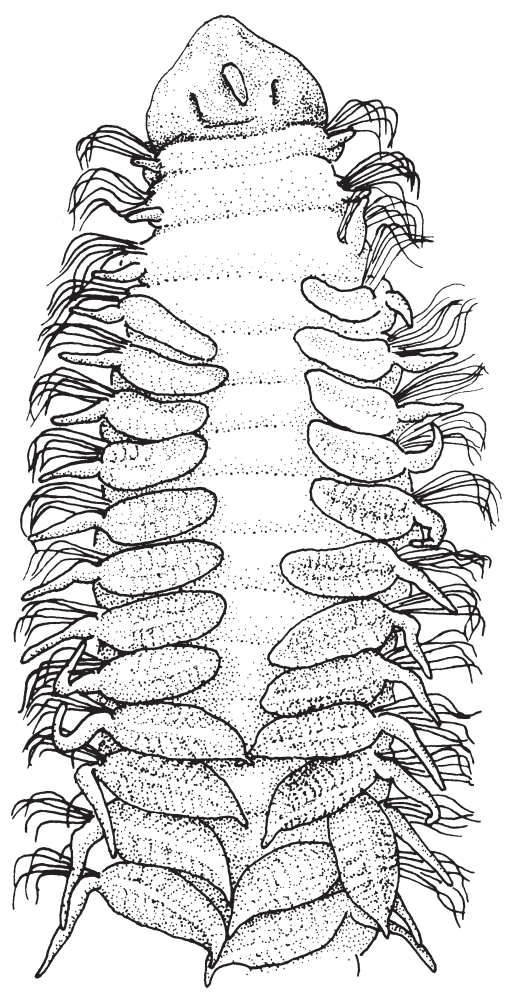

A

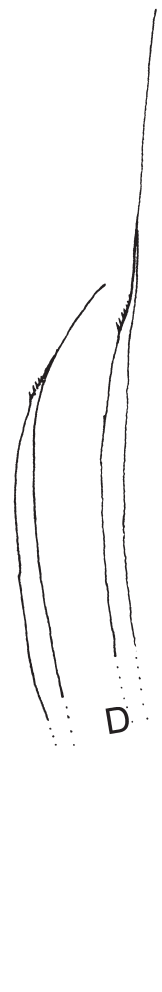

Fig. 22. - Aricidea (Allia) nekanae n. sp.: A, anterior region, dorsal view; B, anterior region, ventral view; C, neuropodium, modified ventral chaetae, chaetiger 40; D, modified ventral chaetae, chaetiger 40. Scale bar: A $665 \mu \mathrm{m}$; B $455 \mu \mathrm{m}$; C $75 \mu \mathrm{m}$; D $65 \mu \mathrm{m}$.

Aricidea (Allia) nekanae n. sp. resembles A. belgicae sensu Imajima (1973), but differs in having very clear ventral postchaetal lobes, reaching the chaetigers 17-18, and two eyes.

Distribution. Capbreton Canyon (Bay of Biscay). 492 to $495 \mathrm{~m}$ depth.

Subgenus Acmira Hartley, 1981

Acesta Strelzov, 1973: 105

Aricidea (Acmira) simonae Laubier and Ramos, 1974 (Fig. 21 B-C)

Aricidea simonae, Laubier and Ramos, 1974:1123-1127, Fig. 9-10. Aricidea (Acesta) simonae, Katzmann and Laubier, 1975: 581.Campoy, 1981: 20.

Aricidea (Acmira) simonae, Hartley, 1981:143-145; Gil and Sardá, 1999: 302-303.

Aricidea punctata, Katzmann, 1973: 287-288, Fig. 1-2.

Material examined. 2 specimens from Capbreton Canyon, Bay of Biscay, Atlantic Ocean (coordinates in Table 1). CB88/DI12 (1), CB88/DI33 (1).

Description. Large specimen $6.68 \mathrm{~mm}$ long, $0.63 \mathrm{~mm}$ wide for 46 chaetigers; small one in poor condition.

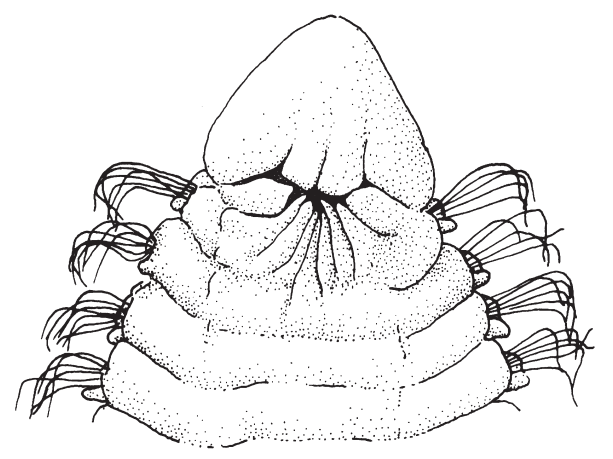

B

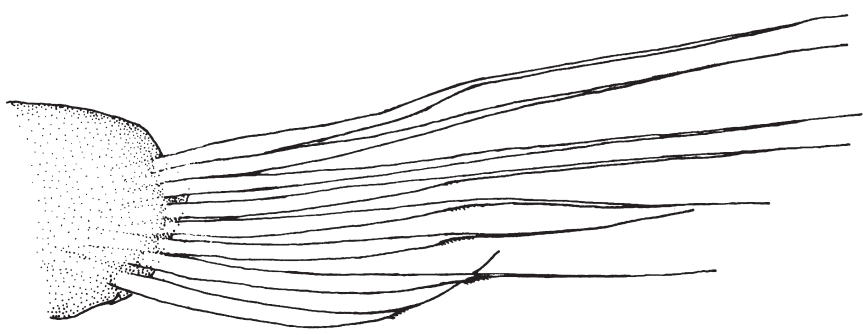

C
Prostomium triangular with median antenna short, slightly inflated distally (Fig. 21B).

First notopodial postchaetal lobe digitiform, longer in chaetiger 2; slightly longer, cirriform from chaetiger 3 (Fig. 21B); long, filiform in posterior region.

Branchiae starting from chaetiger 3 in large specimen, 14 pairs, short, cylindrical, distally rounded; left branchiae of chaetiger 3 much smaller than normal ones, right one only slightly shorter; branchiae starting at chaetiger 4 in small specimens, 7-8 pairs.

Modified ventral chaetae short, acicular, distally curved (Fig. 21C), from chaetigers 29 (large specimen) and 21-22 (small specimen).

Granular brownish pigmented spots in each segment.

Discussion. The number of branchial pairs (from 7 to 14) starting at chaetigers 4 (small specimen) and 3 (large specimen) agree well with Hartley (1981: fig. 4), who reported from 7 to 36 pairs and the same sizerelated variability in the starting branchial chaetiger.

Distribution. Mediterranean, Adriatic, North Sea, Atlantic (30 to $660 \mathrm{~m}$ depth). Capbreton Canyon 

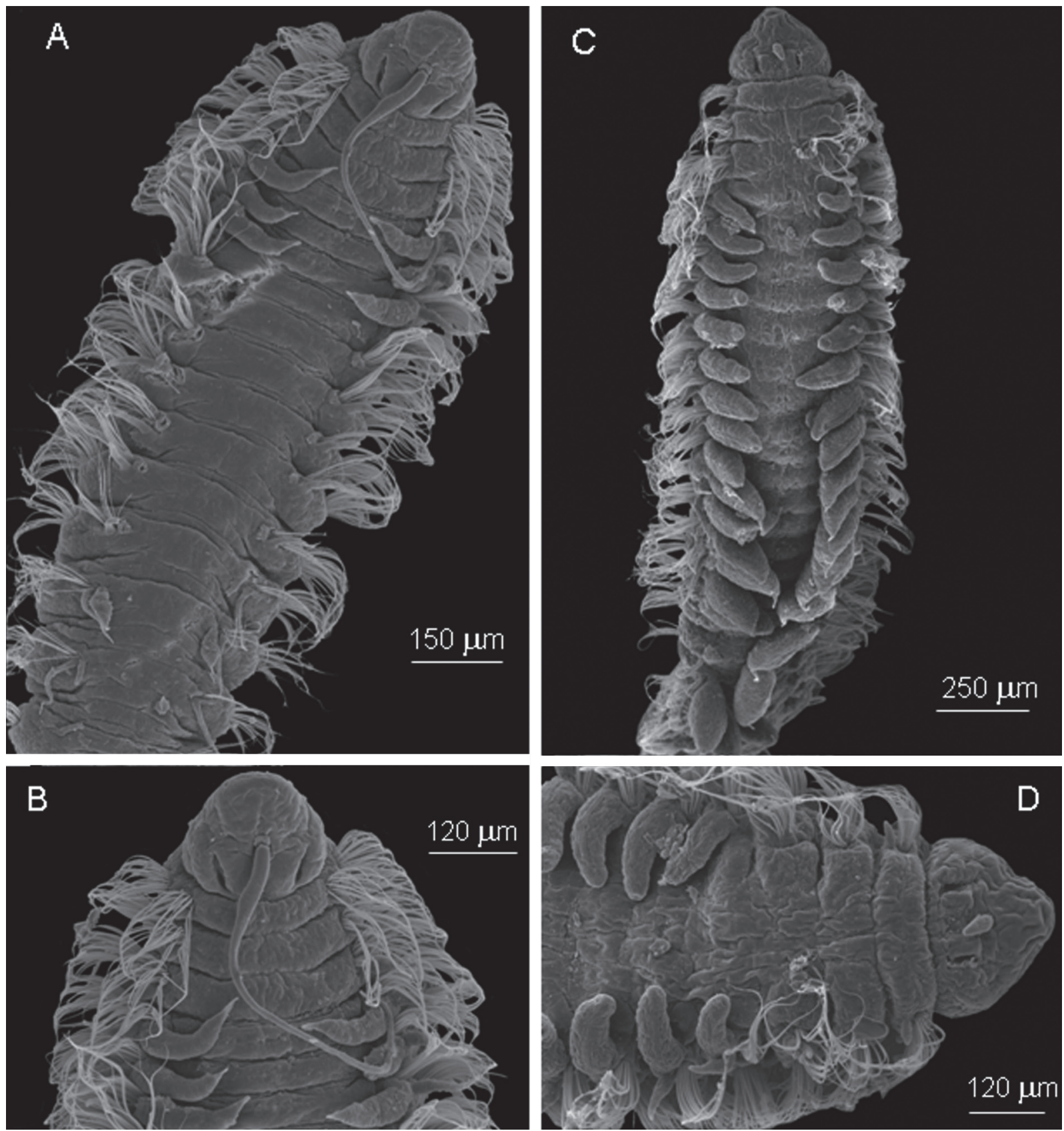

FIG. 23. - Aricidea (Allia) maialenae n. sp.: A-B, anterior region, dorsal view. Aricidea (Allia) nekanae n. sp.: C-D, anterior region, dorsal view. Scale bar: A $150 \mu \mathrm{m}$; B $120 \mu \mathrm{m}$; C $250 \mu \mathrm{m}$; D $120 \mu \mathrm{m}$.

(Bay of Biscay): 492 to $495 \mathrm{~m}$ and 1012 to $1113 \mathrm{~m}$ depth, which extends the bathymetric distribution to deeper waters.

\section{ACKNOWLEDGEMENTS}

Thanks are due to DGO (Talence) for the loan of the Flusha box-corer; to BIMM-MNHN (Paris) for the loan of the sieving equipment; to the French
CIRMAT (INSU-CNRS) for logistical support and loan of an epibenthic dredge; to the crew of the RV "Côte d'Aquitaine" for their helpful assistance at sea; to A. Urzelai, I. Esteban and I. Zabala (INSUB, Donostia) for their helpful contribution to the sorting of Capbreton samples; to Dr. J.C. Dauvin (MNHN, Paris) for kindly providing bibliography; to David Romero (Universidade da Coruña) for providing the final versions of the species drawings and to R. Andrade (UPV-EHU) for the SEM photographs. 
We would like to thank Dr. H. Sattmann (NHM Wien), Dr. M.J. d'Hondt (MNHN Paris) and Dr. M. Lowe (NHM London) for the loan of type material.

This study was partly supported by the French CIRMAT-CNRS (1988-89 CAPBRETON cruises), and by the "Proyecto Fauna Ibérica CGL200404680-C10-02, Ministerio de Educación y Ciencia, Dirección General de Investigación".

We would particularly like to thank Dr. Jean Claude Sorbe, director of Capbreton research.

\section{REFERENCES}

Aguirrezabalaga, F. and A. Ceberio. - 2003. Dorvilleidae (Polychaeta) from the Capbreton Canyon (Bay of Biscay, NE Atlantic) with the description of Pettiboneia sanmartini sp. nov. Cah. Biol. Mar., 44: 41-48

Aguirrezabalaga, F. and A. Ceberio. - 2005a. Sphaerodoropsis amoureuxi and S. stellifer, two new species of Sphaerodoridae (Polychaeta) from the Capbreton Canyon (Bay of Biscay, NE Atlantic). Cah. Biol. Mar. 46: 9-20.

Aguirrezabalaga, F. and A. Ceberio. - 2005b. Spionidae (Polychaeta) from the Capbreton Canyon (Bay of Biscay, NE Atlantic) with description of a new genus and three new species. Mar. Biol. Res., 1: 267-280.

Aguirrezabalaga, F. and A. Ceberio. - 2006. Flabelligena gascognensis (Polychaeta: Acrocirridae) a new species from the Capbreton Canyon (Bay of Biscay, NE Atlantic). Sci. Mar., 70S1 141-147.

Aguirrezabalaga, F. and L.F. Carrera-Parra. - 2006. Lumbrineridae from the Capbreton Canyon (Bay of Biscay, NE Atlantic) with the description of two new species. Sci. Mar., 70S3: 17- 25 .

Aguirrezabalaga, F. and J. Gil. - 2008. Paraonidae (Annelida: Polychaeta) of the inlet of Zarautz (Basque Coast, Bay of Biscay), with new records from the Atlantic and the Iberian coasts. Cah. Biol. Mar., 49: 37-57.

Aguirrezabalaga, F., G. San Martín, M.E. Petersen and A. Ceberio. - 1999. Presencia de Dysponetus gracilis Hartman, 1965 (Polychaeta: Chrysopetalidae) en las costas europeas. Bol. R. Soc. Esp. Hist. Nat. Biol., 95: 21-25

Aguirrezabalaga, F., A. Ceberio and D. Fiege. - 2001. Octomagelona bizkaiensis (Polychaeta: Magelonidae) a new genus and species from the Capbreton Canyon (Bay of Biscay, north-east Atlantic). J. Mar. Biol. Ass. U.K., 81: 221-225.

Aguirrezabalaga, F., A. Ceberio and H. Paxton. - 2002. Onuphidae (Polychaeta) from the Capbreton Canyon (Bay of Biscay, NE Atlantic) with the description of Paradiopatra capbretonensis sp. nov. Steenstrupia, 27: 19-28

Amoureux, L. - 1982. Annélides Polychètes recueillies sur la pente continentale de la Bretagne à 1'Irlande, Campagne 1973 de la "Thalassa" (suite et fin) avec la description de quatre espèces nouvelles pour la Science. II Inventaire taxonomique annoté de toutes les Polychètes Sédentaires. Cah. Biol. Mar., 22: 179-214.

Amoureux, L. - 1985. Annélides benthiques récoltées à l'entrée de la lagune de la Manche-à-Eau, Guadeloupe (Antilles). Bull. Mus. Nat. Hist. Nat. 4A, 7: 93-107.

Annenkova, N.P. - 1934. Paraonidae dal nevostochnykh morei SSSR-Meeres (Paraonidae of the far-eastern seas of the USSR). Dokl. Akad. Nauk. SSSR, 2: 153-194.

Berkeley, E and C. Berkeley. - 1950. Notes on Polychaeta from the Coast of Western Canada.- IV. Polychaeta Sedentaria. Ann. Mag. Nat. Hist., 3: 50-69.

Blake, J.A. - 1996. Family Paraonidae Cerruti, 1909. In: J.A. Blake, B. Hilbig and P.H. Scott (eds.), Taxonomic Atlas of the Benthic Fauna of the Santa Maria Basin and the Western Santa Barbara Channel. Vol. 6. Annelida Part 3. Polychaeta: Orbiniidae to Cossuridae. pp. 27-70. Santa Barbara Museum of Natural History, California.
Brito, M.C. and J. Núñez. - 2002. A new genus and species of Questidae (Annelida: Polychaeta) from the central Macaronesian region and a cladistic analysis of the family. Sarsia, 87: 281-289.

Campoy, A. - 1981. Anélidos poliquetos de la Península Ibérica: Familia Paraonidae. Bol. R. Soc. Esp. Hist. Nat. Biol., 79: 15-26.

Cantone, G. - 1994. Polychaeta "Sedentaria" of Terra Nova Bay (Ross Sea, Antarctica): Orbiniidae to Oweniidae (Annelida). Animalia, 21: 35-47.

Carpine, C. - 1970. Écologie de l'étage bathyal dans la Méditerranée occidentale. Mém. Inst. Ocèanogr., Monaco, 2: 1-146.

Castelli, A. - 1985. Paraonidae (Annelida, Polychaeta) des fonds meubles infralittoraux des côtes toscanes. Cah. Biol. Mar., 26: 267-279.

Castelli, A. - 1988. Censimento dei policheti dei mari Italiani: Paraonidae Cerruti, 1909. Atti Soc. Tosc. Sci. Nat., Memorie, Serie B, 94: 319-340. (dated 1987; published March 1988).

Cerruti, A. - 1909. Contributo all Anatomia, biologia e sistematica delle Paraonidae (Levinsenidae) con particolare riguardo alle specie del golfo di Napoli. Mitt. Zool. Sta. Neapel, 19: 459-512.

Dahlgren, T.G., A.G. Glover, A. Baco and C.R. Smith. - 2004. Fauna of whale falls: systematics and ecology of a new polychaete (Annelida: Chrysopetalidae) from the deep Pacific Ocean. Deep Sea Res. Part II, 51: 1873-1887.

Day, J.H. - 1955. The Polychaeta of South Africa. Part 3. Sedentary species from Cape shores and estuaries. J. Linn. Soc. Lond., 42: 407-452.

Day, J.H. - 1963. The polychaete fauna of South Africa. Part 8: new species and records from grab samples and dredgings. Bull. Br. Mus. (Nat. Hist.) Zool., 10: 383-445.

Day, J.H. - 1967. A Monograph on the Polychaeta of Southern Africa. Brit. Mus. (Nat. Hist.) Publ., 656: 1-878.

Desbruyères, D., A. Guille and J. Ramos. - 1972. Bionomie benthique du plateau continental de la côte catalane espagnole. Vie Milieu, 23B: 335-366.

Desbruyères, D. and A. Toulmond. - 1998. A new species of hesionid worm, Hesiocaeca methanicola sp. nov (Polychaeta: Hesionidae), living in ice-like methane hydrates in the deep Gulf of Mexico. Cah. Biol. Mar., 39: 93-98.

Desbruyères, D., M. Segonzac and M. Bright (eds.). - 2006. Handbook of Deep-sea Hydrothermal Vent Fauna. Second completely revised edition. Denisia, 18: 1-544.

Ehlers, E. - 1908. Die Bodensässigen Anneliden aus den Sammlungen der deutschen Tiefsee-Expedition. In: C. Chun, (ed.), Wiss. Ergeb. Dt. Tiefsee-Exped. "Valdivia", 1898-1899, 16: 1-168.

Eliason, A. - 1920. Biologisch-Faunistische Üntersuchungen aus dem Öresund. V. Polychaeta. Acta Univ. Lund., N.F., Avd. 2, 16: 1-103.

Fauchald, K. and D.R. Hancock. - 1981. Deep-water polychaetes from a transect off Central Oregon. Allan Hancock Found. Monogr., 11: 1-73.

Gaston, G.R. - 1984. Family Paraonidae Cerruti, 1909. In: J.M. Uebelacker, and P.G. Johnson (eds.), Taxonomic guide to the polychaetes of the Northern Gulf of Mexico. Barry A. Vittor and Associates, Inc. Mobile, Alabama, (1) 2: 1-53.

Gaston, G.R. and J.A. McLelland. - 1996. Aricidea (Allia) bryani, a new species of Polychaete (Polychaeta: Paraonidae) from the Northern Gulf of Mexico. Gulf Res. Rep., 9: 189-195.

Giere, O., B. Ebbe and C. Erséus. - 2008. Questa (Annelida, Polychaeta, Orbiniidae) from Pacific regions - new species and reassessment of the genus Periquesta. Org. Div. Evol., 7: 304-319.

Gil, J. and R. Sardá. - 1999. New records of Annelida Polychaeta for the Portuguese fauna (with comments on some already known species). Arq. Mus. Bocage, Nova Ser., 3: 287-336.

Glémarec, M. - 1966. Paraonidae de Bretagne. Description de Paradoneis armata nov. sp. Vie Milieu, 17A: 1045-1052.

Glover, A.G., B. Källström, C.R. Smith and T.G. Dahlgren. - 2005. World-wide whale worms? A new species of Osedax from the shallow north Atlantic. Proc. R. Soc. B, 272: 2587-2592.

Guille, M. - 1970. Bionomie benthique du plateau continental de la côte catalane française. II. Les communautés de la macrofaune. Vie Milieu, 21B: 149-280.

Hartley, J.P. - 1981. The family Paraonidae (Polychaeta) in British waters: a new species and new records with a key to species. $J$. Mar. Biol. Ass. U.K., 61: 133-149.

Hartley, J.P. - 1984. Cosmopolitan polychaete species: the status of 
Aricidea belgicae (Fauvel, 1936) and notes on the identity of $A$. suecica Eliason, 1920 (Polychaeta; Paraonidae). In: P.A. Hutchings (ed.), Proceedings of the First International Polychaete Conference, Sydney, Australia, 1983, pp. 7-20. The Linnean Society of New South Wales, Sydney.

Hartman, O. - 1965. Deep-water benthic polychaetous annelids off New England to Bermuda and other north Atlantic areas. Allan Hancock Occas. Pap., 28: 1-378.

Hartman, O. - 1967. Polychaetous annelids collected by the USNS Eltanin and Staten Island cruises, chiefly from Antarctic Seas. Allan Hancock Monogr. Mar. Biol., 2: 1-387.

Hartman, O. - 1969. Atlas of the Sedentariate Polychaetous Annelids from California. Allan Hancock Foundation, University of Southern California Press, Los Angeles.

Hartmann-Schröder, G. - 1965. Die Polychaeten des Sublitorals. In: G. Hartmann-Schröder and G. Hartmann. Zur Kenntnis des Sublitorals der chilenischen Küste unter besonderer Berücksichtigung der Polychaeten und Ostracoden. Mitt. Zool. Mus. Inst., 62: 59-305.

Hartmann-Schröder, G. - 1974. Zur Polychaetenfauna von Natal (Südafrika). Mitt. Zool. Mus. Inst., 71: 35-73.

Hartmann-Schröder, G. - 1996. Annelida, Borstenwürmer, Polychaeta. 2. neubearbeitete Auflage. Tierwelt Dtl., 58: 1-648.

Hartmann-Schröder, G. and P. Rosenfeldt. - 1988. Die Polychaeten der "Polarstern"-Reise ANT III/2 in die Antarktis 1984. Teil 1: Euphrosinidae bis Chaetopteridae. Mitt. Zool. Mus. Inst., 85: 25-72.

Hilário, A. and M.R. Cunha. - 2008. On some frenulate species (Annelida: Polychaeta: Siboglinidae) from mud volcanoes in the Gulf of Cadiz (NE Atlantic). Sci. Mar., 72: 361-371.

Hobson, K.D. - 1972. Two new species and two new records of the family Paraonidae (Annelida, Polychaeta) from the northeastern Pacific Ocean. Proc. Biol. Soc. Wash., 85: 549-556.

Imajima, M. - 1973. Paraonidae (Polychaeta) from Japan. Bull. Natl. Sci. Mus., Tokyo, 16: 254-292.

Katzmann, W. - 1973. Aricidea punctata n.sp., ein neuer Paraonidae (Polychaeta) aus der Adria. Ann. Nathist. Mus. Wien, 77: 287-288.

Katzmann, W. and L. Laubier. - 1975. Paraonidae (Polychètes sédentaires) de 1'Adriatique. Ann. Nathist. Mus. Wien, 79: 567-588.

Laubier, L. - 1966. Sur la présence du genre Cirrophorus (Polychètes, Paraonidae) en Méditerranée. Bull. Soc. Zool. Fr., 90: 469-477.

Laubier, L. - 1967. Sur quelques Aricidea (Polychètes, Paraonidae) de Banyuls-sur-Mer. Vie Milieu, 18A: 99-132.

Laubier, L. - 1972. A propos d'une espèce de Paradoneis (Polychète, Paraonidae) nouvelle pour la Méditerranée occidentale. Vie Milieu, 22A: 259-262.

Laubier, L. and J. Ramos. - 1974. Paraonidae (Polychètes sédentaires) de Méditerranée. Bull. Mus. Natl. Hist. Nat. 3, 113: 1097-1148 (dated 1973, but printed 30 March 1974).

León-González, J.A, N.A. Hernández-Guevara and J.A. Rodríguez-Valencia. - 2006. Paraonidae (Polychaeta) from western Mexico, with description of two new species. J. Mar. Biol. Ass. U.K., 86: 253-262.

Lovell, L.L. - 2002. Paraonidae (Annelida: Polychaeta) of the Andaman Sea, Thailand. Phuket Mar. Biol. Cent. Sp. Publ., 24: 33-56.

Mackie, A.S.Y. - 1991. Paradoneis eliasoni sp. nov. (Polychaeta:
Paraonidae) from northern European waters, with a redescription of Paradoneis lyra (Southern, 1914). Ophelia, Suppl. 5: 147-155.

McLelland, J.A. and G.R. Gaston. - 1994. Two new species of Cirrophorus (Polychaeta: Paraonidae) from the northern Gulf of Mexico. Proc. Biol. Soc. Wash, 107: 524-531.

Melville, R.V. - 1979. Opinion 1139. Paraonis Grube, 1873. (Polychaeta, Paraonidae). Designation of a type species under the plenary powers. Bull. Zool. Nomencl., 36: 114-118.

Montiel, A. and B. Hilbig. - 2004. Aricidea pisanoi (Annelida: Polychaeta), a new species of Paraonidae from the southernmost waters of South America (Chile). J. Mar. Biol. Ass. U.K., 84: 43-45.

Núñez, J., F. Aguirrezabalaga and A. Ceberio. - 2000. Species of Nereididae from the Capbreton Canyon (Bay of Biscay, NE Atlantic). Bull. Mar. Sci., 67: 25-37

Pettibone, M.H. - 1963. Marine polychaete worms of the New England region. Part 1. Families Aphroditidae through Trochochaetidae. Bull. U. S. Natl. Mus., 227: 1-356.

Pleijel, F., G.W. Rouse, C. Ruta, H. Wiklund and A. Nygren. - 2008. Vrijenhoekia balaenophila, a new hesionid polychaete from a whale fall off California. Zool. J. Linn. Soc., 152: 625-634.

Ravara, A., M.R. Cunha and C.F. Rodrigues. - 2007. The occurrence of Natsushima bifurcata (Polychaeta: Nautiliniellidae) in Acharax hosts from mud vulcanoes in the Gulf of Cadiz (south Iberian and north Moroccan Margins). Sci. Mar., 71: 95-100.

Rouse, G.W., S.K. Goffredi and R.C. Vrijenhoek. - 2004. Osedax: bone-eating marine worms with dwarf males. Science, 305: 668-671.

Rouse, G.W., K. Worsaae, S.B. Johnson, W.J. Jones and R.C. Vrijenhoek. - 2008. Acquisition of dwarf males "harems" by recently settled females of Osedax roseus n.sp. (Siboglinidae; Annelida). Bioll. Bull., 214: 67-82.

San Martín, G., A. Ceberio and F. Aguirrezabalaga. - 1996. Exogone species (Polychaeta: Syllidae: Exogoninae) from the Capbreton Canyon (Bay of Biscay, NE Atlantic). Cah. Biol. Mar., 37: 249-258.

Storch, V. - 1967. Neue Polychaeten aus der Sandfauna des Roten Meeres. Zool. Anz., 178: 102-110.

Strelzov, V.E. - 1968. Polychaetous annelids of the family Paraonidae (Polychaeta, Sedentaria) of the Barents Sea. Tr. Murmanks Morsk. Biol. Inst., 17: 74-95. (In Russian)

Strelzov, V.E. - 1973. Polychaete worms of the family Paraonidae Cerruti, 1909 (Polychaeta, Sedentaria). Akademiya Nauk SSSR, Leningrad, 1-170, plates 1-9. (In Russian)

Tauber, P. - 1879. Annulata Danica. En kritisk revision af de i Danmark fundne Annulata Chaetognatha, Gephyrea, Balanoglossi, Discophoreae, Oligochaeta, Gymnocopa og Polychaeta. Reitzel, Copenhagen.

Uschakov, P.V. - 1955. Polychaeta of the far eastern seas of the USSR. Fauna SSSR, 56: 1-443. (In Russian)

Webster, H.E. and J.E. Benedict. - 1887. The Annelida Chaetopoda from Eastport, Maine. Rep. U.S. Fish Comm., 1885: 707-755.

Zachs, I. - 1925. Nouvelles additions à la faune Polychaeta du Nauman. C.R. Acad. Sci. URSS, Sec. A, 1925: 1-3.

Scient. ed.: D. Martin.

Received September 22, 2008. Accepted January 26, 2009.

Published online July 6, 2009. 